PHILIPPINE AGRICULTURE

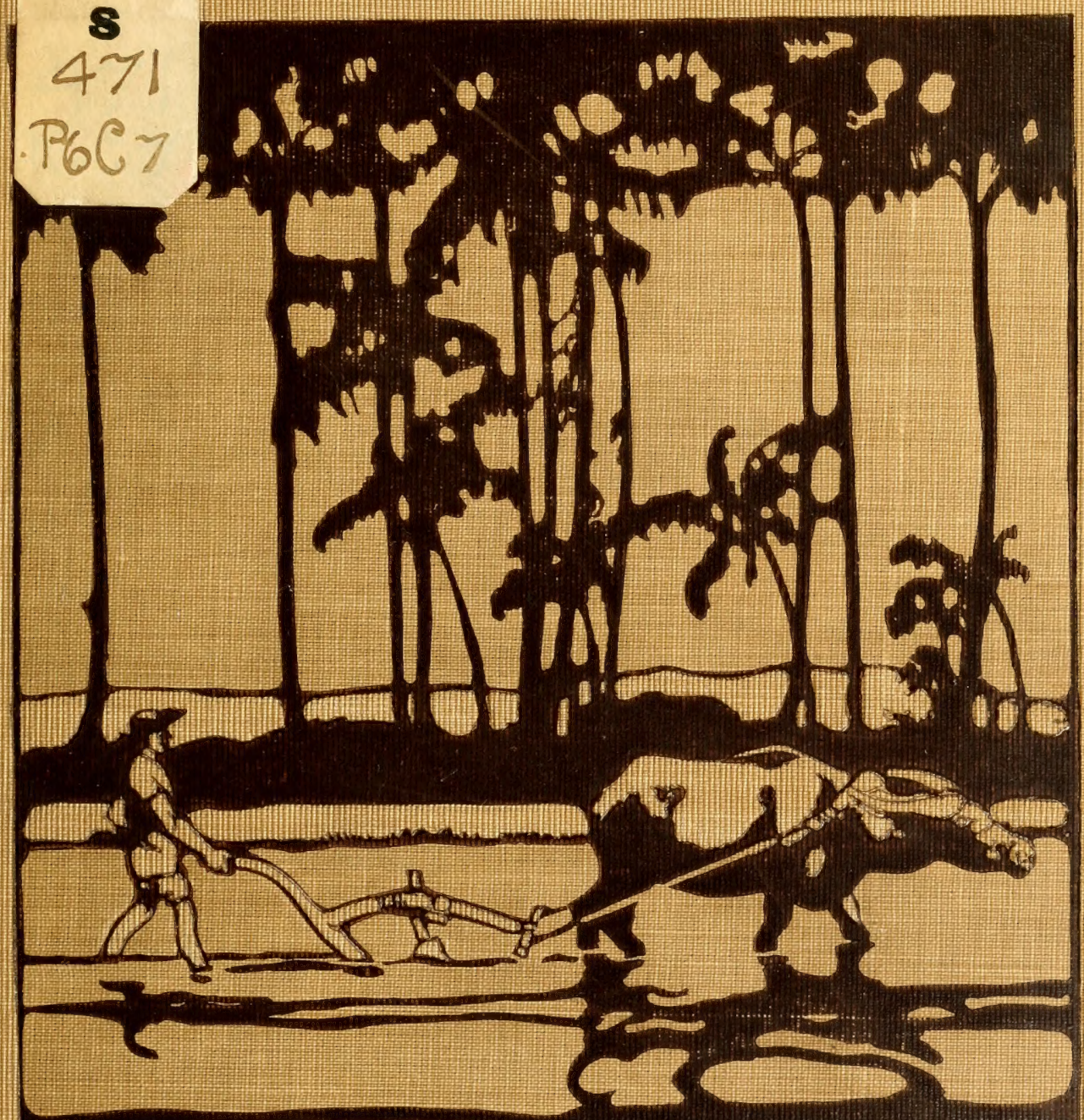

WORLD BOOK COMPANY 

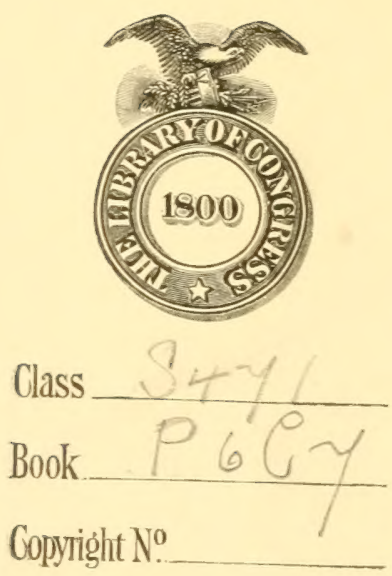

COPYRIGHT DEPOST: 
PHILIPPINE EDUCATION SERIES

ELEMENTS OF

PHILIP PINE

A GR I C ULT UR E

BY

EDIVIN BINGHAM COPELAND, Ph.D.

SUPERINTENDENT OF THE INSULAR AGRICULTURAL

SCHOOL OF THE PHILIPPINE ISLANDS

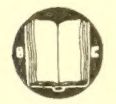

YONKERS-ON-HUDSON, NEW YORK

WORLD BOOK COMPANY

AND MANILA

I908 


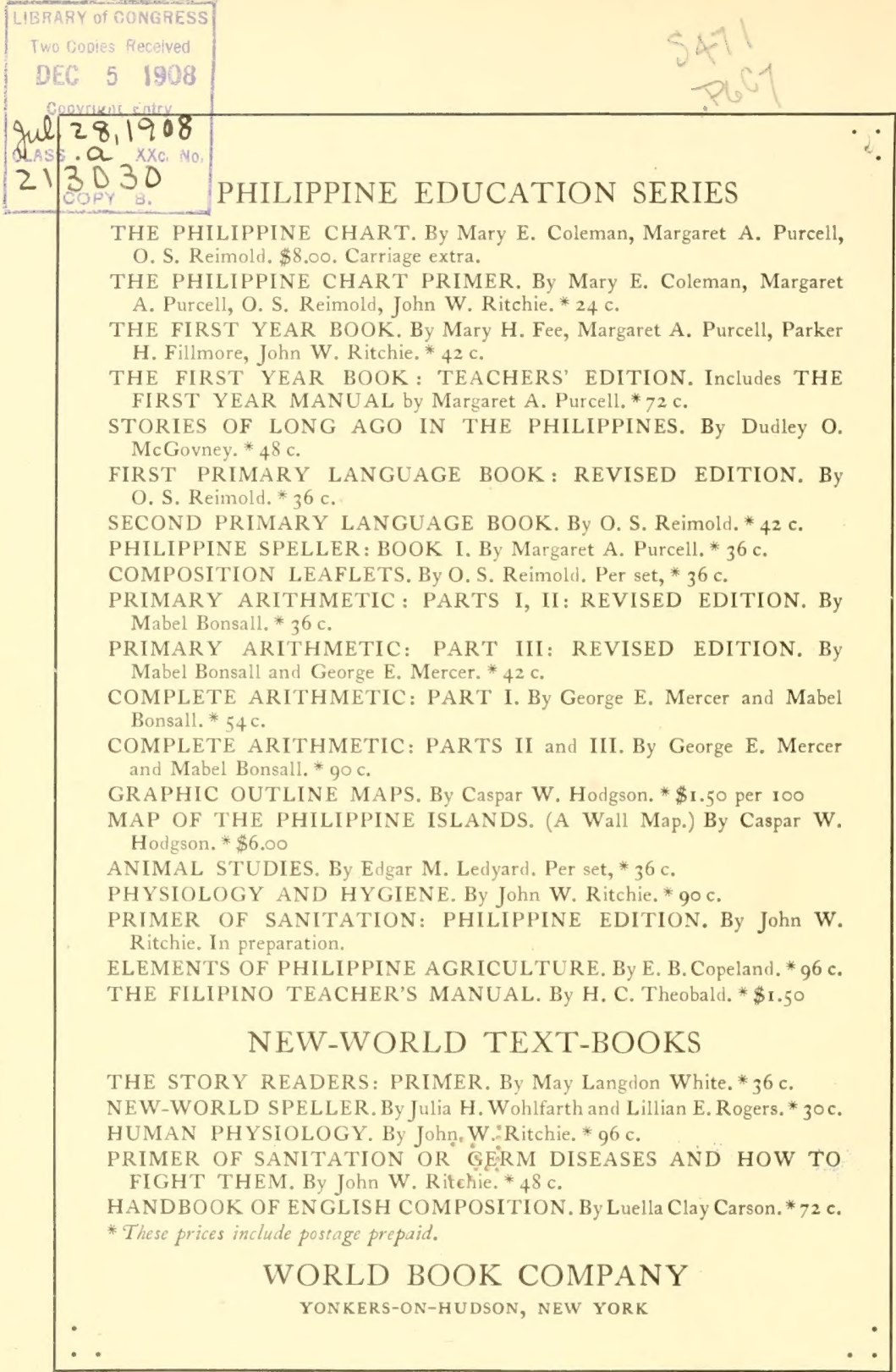

THE PHILIPPINE CHART. By Mary E. Coleman, Margaret A. Purcell, HE PHILIPPINE CHART PRIMER, By Mary E. Coleman, Margaret A. Purcell, O. S. Reimold, John W. Ritchie. ${ }^{*} 24$ c.

HE FIRST YEAR BOOK. By Mary H. Fee, Margaret A. Purcell, Parker H. Fillmore, John W. Ritchie. * $42 \mathrm{c}$.

FEAR BOOK: TEACHERS

TORIES OF LONG AGO IN THE PHILIPPINES. By Dudley O.

IRST PRIMARY LANGUAGE BOOK: REVISED EDITION. By O. S. Reimold, * 36 c.

SECOND PRIMARY LANGUAGE BOOK. By O. S. Reimold, * 42 c.

PHILIPPINE SPELLER: BOOK I. By Margaret A. Purcell.**36 c.

COMPOSITION LEAFLETS, By O. S. Reimold. Per set, ${ }^{*} 36 \mathrm{c}$.

RIMARY ARITHMETIC: PARTS I, II: REVISED EDITION. By Mabel Bonsall. * $36 \mathrm{c}$.

RIMARY ARITHMETIC: PART III: REVISED EDITION. By Mabel Bonsall and George E. Mercer. * $42 \mathrm{c}$.

OMPLETE ARITHMETIC: PART I. By George E. Mercer and Mabel Bonsall. * $54 \mathrm{c}$.

OMPLETE ARITHMETIC: PARTS II and III. By George E. Mercer Ponsall. * $90 \mathrm{c}$

GRAPHIC OUTLINE MAPS. By Caspar W. Hodgson. *\$1.50 per 100 AP OF THE PHILIPPINE ISLANDS. (A Wall Map.) By Caspar W.

ie. * $90 \mathrm{c}$

PRMER OF SANTTAION: PHILIPPINE EDITION. By John W.

ELEMENTS OF PHILIPPINE AGRICULTURE. By E. B. Copeland. ${ }^{*} 96 \mathrm{c}$.

\section{NEW-WORLD TEXT-BOOKS}

THE STORY READERS: PRIMER. By May Langdon White. ${ }^{*} 36 \mathrm{c}$.

NEW-WORLD SPELLER. By Julia H. Wohlfarth and Lillian E. Rogers.* $30 \mathrm{c}$. HUMAN PHYSIOLOGY. By John, W.:Ritchie, * $96 \mathrm{c}$.

RIMER OF SANITATION OR GERM DISEASES AND HOW TO FIGHT THEM. By John W. Ritehie. * $48 \mathrm{c}$.

HANDBOK OF EN GLISH COMPOSITION. By Luella Clay Carson, * $72 \mathrm{c}$

* These prices include postage prepaid.

Copyright, 1908, by World Book Co. Entered at Stationers' Hall, London Registrado en las Islas Filipinas. All rights reserved 


\section{PREFACE}

THE general principles and a large part of the facts to be taught in most subjects in the elementary schools are the same in every land. Some subjects might be taught in the Philippine Islands from American texts, except as they gain in presentation by the use of local examples and illustrations. With agriculture the case is very different. The subjects to be studied are almost all different from those in the United States; the climate is different, the economic conditions are different. A useful text-book must be adapted to all of these differences.

Our text-books are the products of evolution, those in use to-day having the good features but, as far as can be helped, not the weaknesses of their predecessors. The teaching of agriculture in any large number of schools is so recent that this selection has not yet gone far. Even in temperate countries, there has not yet been time for general experience to decide what material, from the almost unlimited amount available, should be chosen for school use; the methods of presenting it are as diverse as the limited number of books permits, and a logical relation of the material seems as yet to have been less considered by most authors than the exercise of the eyes and hands and the teaching of mere facts.

In a subject in which texts are still so undeveloped, and in the first attempt in a tropical field, ${ }^{1}$ it is inevitable that this book will be far from what many will think it should be. Under the circumstances, I trust that their criticisms will be constructive, and that they will be sent to the author.

There is nothing unreasonable in good agriculture, and the fact that a text on the subject must be practical does not involve its being disconnected or illogical. I believe that whatever success has rewarded my effort to present this subject logically increases, instead of detract-

1 Lyon's interesting reader is not, and is not called, a text-book of agriculture. 
ing from, its practical value; for every student is most certain to remember, and most likely to practice, the things he really understands. There are, of course, practical limits to explanations; I have had to use my own judgment as to where these limits are reached.

My work on this little book has covered more than two years. It was at first proposed that a set of leaflets on Philippine agriculture be written, and Mr. Edgar M. Ledyard was associated with me in their preparation. Later, when it was decided that a book, rather than a set of leaflets, was needed, a more homogeneous treatment became necessary, and being absent from the Philippines, I completed it alone, and am individually responsible. I wish to express here my obligation to Mr. Ledyard for his help on the preliminary work, and for helpful criticism of the completed manuscript. For helpful criticism and suggestions, thanks are also due Dr. David P. Barrows, Director of Education for the Philippine Islands; C. W. Burkett, joint author of Agriculture for Beginners; K. L. Hatch, joint author of Elementary Agriculture; W. J. Spillman, United States Department of Agriculture; John W. Ritchie, author of the Physiology and Hygiene used in the Philippines; E. N. Henderson, Adelphi College, Brooklyn, N.Y.; F. M. De Forest, St. Paul's School, Concord, N.H.; W. W. Rodwell, Division Superintendent, Laguna Province, P.I. ; and H. H. Buck, Division Superintendent, Batangas Province, P.I.

For the use of photographs, many of which are copyrighted, acknowledgment is made to Hon. Dean C. Worcester, Secretary of the Department of the Interior, Philippine Islands; the United States Department of Agriculture, Washington, D.C.; La Hacienda; The World's Work; Dr. Harold W. Fairbanks; Professor John W. Ritchie; and Caspar W. Hodgson.

Finally, my greatest obligation is to the publishers, who have been most generous of time, labor, and expense.

\section{EDWIN BINGHAM COPELAND}

MANiLA, February 29, I908 


\section{CONTENTS}

List OF Illustrations . . . . . . . . . . . vii

TO THE TEACHER . . . . . . . . . . . . xi

INTRODUCTION . . . . . . . . . . . . . I

CHAPTER

I. Plants . . . . . . . . . . 3

II. The SeED . . . . . . . . . . II

III. THE SOIL . . . . . . . . . . . I6

IV. The FoOd OF Plants. . . . . . . . 24

V. Plants and Light . . . . . . . 32

VI. Plants and Water . . . . . . . . 35

VII. Climate and Agriculture . . . . . . . 46

VIII. The Living Enemies of Crops . . . . . . 53

1X. THE GARDEN . . . . . . . . 6I

X. Starch Plants . . . . . . . . . . 82

XI. MAIZE . . . . . . . . . . . . . 90

XII. RICE . . . . . . . . . . . 103

XIII. SUgar-CANE . . . . . . . . . II2

XIV. The Coconut . . . . . . . . . . . 122

XV. Fiber Plants . . . . . . . . . . I33

XVI. ТовАсСО . . . . . . . . . . . . I50

XVII. COFFEE. . . . . . . . . . . 160

XVIII. CACAO . . . . . . . . . . . . 168

XIX. FrUITS. . . . . . . . . . . 173

Glossary . . . . . . . . . . . . . 187

INDEX . . . . . . . . . . . . I90 


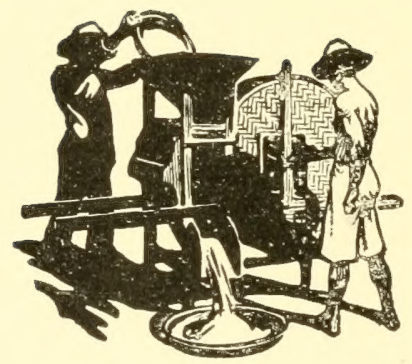




\section{LIST OF ILLUSTRATIONS}

1.11;

I. Map of garden plot

I. $+1,1$

I. Map of garclen plot

2. Mushroom . . . . . . . . . . . . . . . . . 5

3. White American bean . . . . . . . . . . . . . . 6

4. Sinamay . . . . . . . . . . . . . . . . . . . . 7

5. Seedling bean . . . . . . . . . . . . . . . . . .

6. Stem of bambon . . . . . . . . . . . . . . . . . ()

7. Parts of a leaf . . . . . . . . . . . . . . . . (1)

8. Parts of a flower. . . . . . . . . . . 10

9. Parts of a seed . . . . . . . . . . . . 11

10. Split coconut showing husk. . . . . . . . . . I 2

I I. Squash seed . . . . . . . . . . . . . . . 13

12. Germinating squash seed . . . . . . . . . . . $\quad$. 3

I3. Germinating bean . . . . . . . . . . . . . 13

If. Sprouting coconuts . . . . . . . . . . . . . 14

I5. Germinated maize . . . . . . . . . . . . I4

I6. Jack-fruit showing seeds . . . . . . . . . . 15

17. Papaya showing seeds. . . . . . . . . . . . 1 . .

18. Diagram of soil, sulssoil, and rock . . . . . . . . . .

19. Church tower overgrown with plants . . . . . . . 1;

20. Rocks standing out on seacoast . . . . . . . . 18

21. Stones in soil . . . . . . . . . . Iu

22. Fertile alluvial soil in a valley . . . . . . . . . . 20

23. A sandy beach . . . . . . . . . . . 22

27. Coconuts from fertilized and unfertilized land . . . . . . . . .

25. Tubercles on roots of bean plant . . . . . . . 2)

26. Maize in rich soil. . . . . . . . . . . . 30

27. Maize in sand or gravel . . . . . . . . . . . 30

28. Stem placed in red ink (experiment) . . . . . . . . . . . .

29. Particles of soil . . . . . . . . . . . . . . . . . . .

30. Root hairs . . . . . . . . . . . . . . .

31. Soil very badly cracked . . . . . . . . . + +1 
$114 \mathrm{i}$.

32. Arid land before irrigation . . . . . . . . . 43

33. Arid land after irrigation . . . . . . . . . . 44

34. Irrigation ditch . . . . . . . . . . . 45

35. Rainfall map . . . . . . . . . . . . 49

36. Locust . . . . . . . . . . . . 53

37. Metamorphosis of the coconut beetle . . . . . . 54

3 K. Catching a swarm of locusts . . . . . . . . . . . . . . 55

39. Spraying machine. . . . . . . . . . . . . . . 56

40. Coffee plant stripped by rust . . . . . . . . . . . . . . 58

4r. Philippine Normal School garden . . . . . . . . . 62

42. Hoe and rake . . . . . . . . . 63

43. Spade and fork . . . . . . . . . . 64

44. Seed box to protect seed from ants . . . . . . . 65

45. Sweet potato, or camote . . . . . . . . . 67

f6. Ubivine . . . . . . . . . . . . . . .

47. Taro, or gabi . . . . . . . . . . . . . . . . . . .

4i. Beet. . . . . . . . . . . . 60)

49. Turnip. . . . . . . . . . . 70

50. Radish. . . . . . . . . . . . . 70

51. Garlic . . . . . . . . . . . . . . . . . . . . .

52. A field of onions. . . . . . . . . . . . . . . . . . . . . . . . . .

53. A cabbage field . . . . . . . . . . . . . 72

54. A head of lettuce . . . . . . . . . . . . 73

55. Cucumber . . . . . . . . . . . . 73

56. Squash. . . . . . . . . . . . . . . 74

57. Ampalaya . . . . . . . . . . 74

5^. Field of watermelons . . . . . . . . . . . . . . . 75

59. Sitao . . . . . . . . . . . . . 77

6o. Peanut plant with fruit . . . . . . . . . 78

6I. Okra . . . . . . . . . . . . . . . 79

6.2. Tomatoes, boxed for market . . . . . . . . . . So

63. American eggplant . . . . . . . . . . S1

6. Philippine eggplant . . . . . . . . . . . $8 \mathbf{I}$

65. Red pepper. . . . . . . . . . . 8 . .

66. Maniok, or cassava . . . . . . . . . . . . . . $S_{3}$

67. Potatoes . . . . . . . . . . . . . 87

68. Arrowroot . . . . . . . . . . . . . . . . . . . . . . . 88

6). Field of maize . . . . . . . . . . . . 90 
FIG.

r.m.

70. Stalk of maize showing inflorescences . . . . . . . . . (1

71. Diagram of pistillate inflorescence . . . . . . . . . . . . .

72. Ear of maize in husk . . . . . . . . . . . . . . . . . . . . . . .

73. Several varieties of maize . . . . . . . . . . . . . .

74. Philippine plow . . . . . . . . . . . . . . . . . . .

75. Modern steam gang plow . . . . . . . . . (x)

76. Maize - cultivated . . . . . . . . . . . I00

77. Maize - neglected . . . . . . . . . 101

78 . Head of rice . . . . . . . . . . 103

70. Terraced rice paddies . . . . . . . . . . . 107

So. Igorot women transplanting rice . . . . . . . . . Io9

Si. Old way of threshing rice. . . . . . . . . IIO

S2. A modern rice thresher . . . . . . . . III

83. Stalk of sugar-cane . . . . . . . . . . II

S4. Apex of stem of sugar-cane . . . . . . . II7

85. Philippine sugar mill . . . . . . . . . . . . I I9

86. Sugar-cane in flower . . . . . . . . . . . . 120

87. Things made from coconut shells . . . . . . . 122

8s. Coconut trees on the seashore . . . . . . . . . . . . . . . . .

So. Flowers and fruit of the coconut tree . . . . . . . . . 125

90. Coconut groves . . . . . . . . . . . . 127

9I. Coconuts germinating in seed bed . . . . . . . 129

92. Husking coconuts . . . . . . . 130

93. Collecting tuba . . . . . . . . . 13I

94. Field of abacá . . . . . . . . . . . . 133

95. Taking abacá fiber to market . . . . . . . . . 135

96. Primitive abacá press . . . . . . . . . . . . 136

97. Bunch of abacá fruit . . . . . . . . . . . . . . . . . . . .

9.i. Abacá fruit showing seeds . . . . . . . . . . I39

99. Removing outer strips of abacá stems . . . . . . 1 . . .

I00. Splitting abacá before stripping . . . . . . I I

IOI. Stripping abacá . . . . . . . . I . 12

102. Drying abacá . . . . . . . . . . . I 43

103. Maguey plants . . . . . . . . . . . I4t

104. Pineapple plants in fruit . . . . . . . I . . . . .

105. Cotton field and cotton-picking machine . . . . . Ifi

Io6. Flower of the tobacco plant . . . . . . I5I

107. A well-cultivated tobacco field . . . . . . I55 
Fil: $\quad$ PAGE

I08. Tobacco plant . . . . . . . . . I58

I09. Coffee fruit . . . . . . . . . . . 160

I ro. Coffee plantation . . . . . . . . . . . 165

I I . Drying coffee . . . . . . . . . . . . . 166

I I2. Healthy young cacao tree . . . . . . . . . . 168

I13. Cacao tree in fruit . . . . . . . . . . 172

IIf. Bunch of latandan bananas . . . . . . . . 174

I15. The morada banana . . . . . . . . . . 175

I I6. Papaya tree in fruit . . . . . . . . . 177

II7. Pomelo . . . . . . . . . . . 178

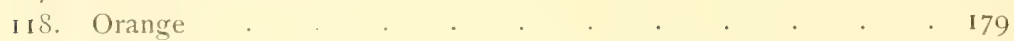

II

120. Mango tree. . . . . . . . . . . 180

12I. Inarching . . . . . . . . . 181

122. Mangosteen . . . . . . . . . . 183

123. Atis . . . . . . . . . . 183

124. Chico. . . . . . . . . . . . 184

125. Guavas . . . . . . . . . . . . . . 184

I26. Breadfruit . . . . . . . . . . . . 185 


\section{TO THE TEACHER}

No teacher of this subject may forget that its value is in its practice; that it is studied not, in the end, for the sake of what can be learned, but for the sake of what can be done with what is learned. Fully half of every student's work in agriculture shoulit be devoted to his garden, and to the preparation of reports on his work there.

The Note-Book. Each student should have a note-book. In it he should report fully everything that he does, his reason for doing it, and what it teaches him. Each day's work should be written up in the notebook on that day. The teacher can have the notes kept satisfactorily only by examining the note-books often and without previous notice. From the daily notes the students should compile reports on the different plants with which they work. For the sake of completeness and convenience as to inspection and use, these reports should be uniform in arrangement. The following general form may be used, with the facts called for put in the note-book under each heading:

Seed : Origin.

Time required for germination.

Germinating power (per cent which germinate).

Date of planting.

Transplanting (if done): Date, and size of plants.

Soil: Sand, loam, or clay.

Preparation.

Cultivation: Dates and method.

Irrigation: Dates and amount.

Date of flowering.

Date of maturity.

Crop: Part of plant used; amount.

How harvested.

Treatment of crop.

Uses.

Enemies: Methods of combating them.

Influence of condition on growth, development, and maturing.

Comparison with work of other students. 
Beets: planted Oct. I8. Rows $50 \mathrm{~cm}$ apart; plants $25 \mathrm{~cm}$ apart. Page - - *

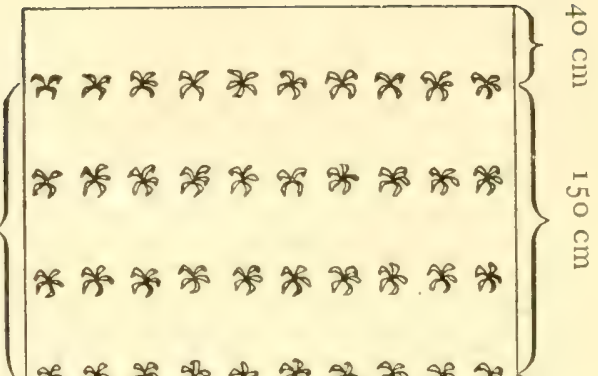

I.ettuce: planted (3) Oct. I9. Rows $30 \mathrm{~cm}$ (3) (3) (3) (3) (3) (3) (3) (3) (3)

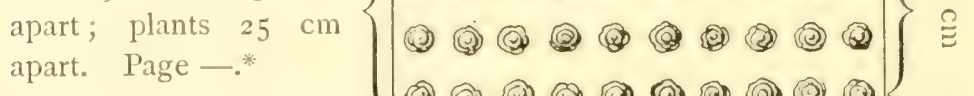

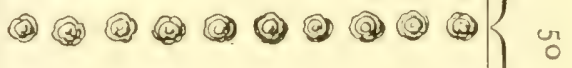

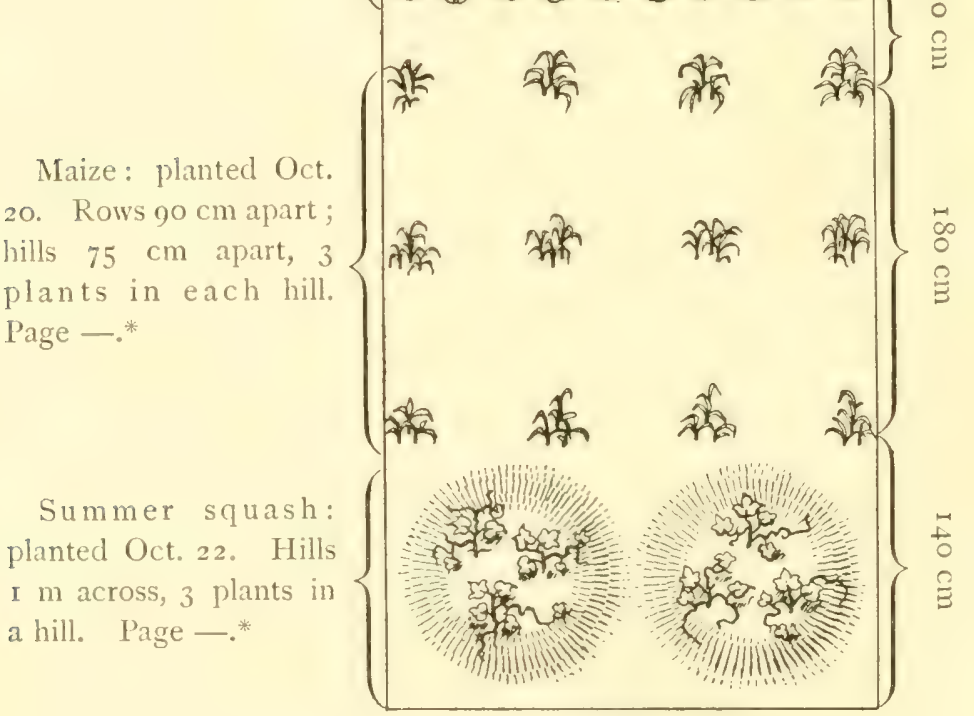

FIG. I. Map of garden plot. Scale: $2 \mathrm{~cm}=\mathrm{I} \mathrm{m}$

* This refers to the page in the student's note-book. 
The School Garden. Every school in which agriculture is taught must of course have a garden, which ought to be large enough to give each student sufficient ground so that its thorough cultivation will require nearly half of the time he has for this study. This ground should be typical of the land in the community. If the garden is put on much better ground than most of that about it, the students may not learn so well from their garden work how to work on other soil. The first thing that must be provided for a school garden, after securing the land, is a good fence. It does not pay to raise tomatoes and beans for pigs and goats. It is usually a part of agriculture for men to keep their lands fenced, and in school the students should do this work.

The Student's Plot. 'The size of plot for each student must depend upon the available land; 5 meters by $2 \frac{1}{2}$ is a good size, but it is possible for a student to keep in proper cultivation a plot at least one half larger than this. Rather than make the plots much smaller, let two students be assigned to each; for if the plots are too sma!l, the distance between the plants will fail to show the importance of space in gardening. The paths between the plots may be $30 \mathrm{~cm}$ to $50 \mathrm{~cm}$ wide.

Mapping the Plot. Each student should map his plot with the utmost exactness, everything on the map being according to a fixed scale. One to fifty is a good scale; on this scale $2 \mathrm{~cm}$ on the map will equal I meter on the garden. A larger scale is still better, if it does not make the map too large for a page of the note-book.

After the comers of his plot are marked and he has some ground cultivated, the student should take a rule and measure off a fixed distance from each of the corners at one end, and mark this distance with a small stake. The line connecting these stakes is parallel to the end of the plot. If it is $20 \mathrm{~cm}$ from the end of the plot, it will be $4 \mathrm{~mm}$ from the end of a map whose scale is one to fifty. If a row of plants is put along this line, the plants should be exactly on it. Do not tolerate inaccuracy in the measurement of the plot, in the notes, or in the maps. Even the distance between individual plants should be fixed and exact, and shown in proper proportion on the map. The map will not be made all at once; but as soon as part of the plot is planted, that part will be drawn on the map. Along the sides of the map should be the 
names of the plants, with a reference in each case to the page in the note-book where the experiment with this plant is described.

Choice of Plants. In deciding what plants shall be cultivateri in the school garlen, first choice must be given to the plants in cultivation by the people of the locality. With these it will be well to cultivate also some plants locally unused, but cultivated elsewhere in the l'hilippines or elsewhere in the world. Most of the plants now cultivated in the Philippines are natives of other countries; and the most valuable plants of other tropical countries are now cultivated in the Philippines. The seeds for each student's planting must be so chosen that he will have work throughout the school year. If plants which mature quickly, such as the rarlish, are planted early in the year, other plants should be ready to take their place as soon as the ground is vacant.

Plant Records. A part of the garden area should be used for the cultivation of perennial plants. In this part every school should endeavor to have growing every perennial plant that is of real economic importance in cultivation anywhere in the Islands. This part of the garden will illustrate the lessons dealing with these plants. In most gardens it will be impossible for each student to cultivate all the important plants grown by any student. However, none, even those which he does not himself cultivate, should be wanting from any student's note-book. The teacher should know the exact history of each plant, and should see that the students' note-books contain as complete an account as possible of every plant cultivated, according to the tabulated form already given. These accounts should be put in the notebooks when the plants in question are studied in the text-book. In reporting the plants he did not cultivate, the student should tell where he obtained the results stated and should be very concise; if possible, he should in such cases report averages from several plots rather than the work of any one student.

Questions and Directions. In most of the chapters in this book are questions, or directions for work, printed in a smaller type than is used for the text. These questions should invariably be answered in the note-book, and reports on the work called for should be written in full. 
Value of Demonstration. 'The good teather will always demonstrate everything possible. It will be especially necessary for the teacher to give to students who have not studied plant life good demonstrations of the facts learned in that study, which this book assumes all students to know. For instance, if the students do not already know them well, the teacher should show them every part of all the plants studied, and tell the name of each part and what it does. There are concise definitions in the glossary, which will be helpful in this work, both to student and teacher. But no good teacher will leave students to learn the use of many words, or expect them to acquire a knowledge of the structure of plants, or of the parts of plants, from such a condensed treatment as is possible in this glossary or in the body of the book.

Tools. The use of tools cannot be taught by a book. If the school has tools, a book is not needed to teach what is most important about their use. And if a school is without certain tools, a book will certainly lo no service by devoting much space to describing them and explaining their use. 


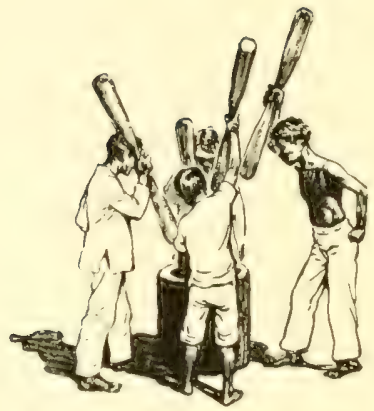




\section{INTRODUCTION}

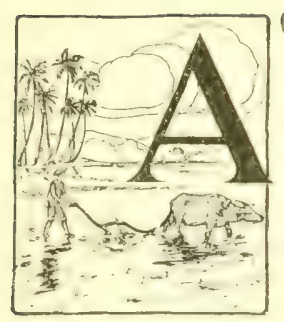

GRICULTURE is one of the oldest occupations of civilized men, and is still the most essential form of human industry; for agriculture supplies the food of most people, and most of the raw material for manufacture.

This book is an attempt to present concisely the fundamental facts about Philippine agriculture, and to show the relation of these facts to one another.

Agriculture is more important in the Philippines than in countries of the temperate zones, because there are few manufactures, and the soil and climate are especially favorable to the growth of plants. Because of this advantage, agriculture will surely continue to be the chief oceupation in these Islands, and no other sulsject studied will have so great an industrial value as this one.

In its narrowest sense, agriculture is the cultivation of the fields. In the broader sense in which we are using the word, it includes gardening, as well as the study of the origin and nature of soils, of the different cropses, and of the uses of these crops.

Before students are ready to study agriculture, they 
must know something about the life of plants. and the principal facts of physical and political geography. Agriculture is usually understood as including also the care of domesticated animals, and in some countries this is its most important part. But in the Philippines animal husbandry is unimportant compared to plant industry: for no animal product is a usual article of export, and the principal local use of animals is in the cultivation of plants. Therefore, the study of agriculture in the Philippines includes little besides the study of cultivated plants.

The need of the study of agriculture is the greater because the fields are now far less productive than they ought to be. Sugar lands here produce one quarter of what lands no better are made to produce in Hawaii; coconut trees are half as productive as in Ceylon; most of the coffee plants are dead; sweet potatoes and maize are very poor; and cassava is neglected, while starch, which can be made from it, must be imported from Anerica. The backwardness of Philippine agriculture will of course never be overcome as a result of school work alone, even if the work be done in the high schools, where it may be done most effectively. But there are more heads and more hands in the work of the lower schools. The boys who study agriculture must know that they are not only preparing themselves for the most general industry of these islands, but are helping by their work, in school and after school, in the uplifting of their people. 


\section{CIIATER I}

\section{PLANTS}

Plants and Animals. Everybody can tell a typical plant from a typical animal. Maize is a typical plant; so is a tree or a bush. The carabao is a typical animal; dogs, birds, and insects are other typical animals.

Plants cannot Move. Plants live all therir lives in one place; while animals walk, or fly, or swim, or crawl. Everybody knows why animals move. They move to get food.

Plants are living things, just as surely as animals are; and since they are living things, they, too, must have food. The food of plants must be made up of things which are where the plants grow; or else the plants, because they cannot move to get their food, would starve.

Foods of Plants. Water is one of the most important foods for plants. There is water in the soil, and the roots get this water for the plant. Dissolved in this water are other foods which plants need. Plants also get much food out of the air. One of the substances which make up the air is carbon dioxid. This substance is injurious to animals, but a most important food for plants. It is being formed all the time, by the breathing of living things, and by the burning of wood, coal, and oil. 
How Plants make Food. It is only in the light that plants are able to use carbon dioxid as a food. Carbon is taken from the air by the leaves. The leaves contain a green substance called chlorophyll. It is because they have this green substance that plants can use the carbon dioxid as a food. This chlorophyll absorbs the light. By means of the light which is absorbed by the chlorophyll, the carbon dioxid in the leaves is united with the water taken up by the roots, and forms sugar, which is a plant food.

How Plants differ from Animals. You have learneci that plants, like animals, are living things. You have also found out that typical plants differ from animals. They differ in four important respects:

I. Plants are green, containing a green pigment, or color-body, chlorophyll, which is not found in animals.

2. By means of chlorophyll, plants absorb the sunlight, and by means of the light, they can make organic food, such as sugar, from the inorganic substances, carbon dicxid and water.

3. Since these very simple food substances, carbon dioxid and water, are almost everywhere in the world, plants need not move to get their food. Therefore, plants are stationary.

4. Since plants are stationary, they can protect themselves with rigid cell walls. These are made of cellulose. Since animals must move to get their food, they can have no such rigid cell walls.

There are many plants which are not typical. Mush- 
rooms, for instance, are without chlorophyll, and therefore cannot make their own organic food. But they are known to be plants, because certain things show that they are descended from typical plants.

Since Philippine agriculture is almost entirely devoted to plants, the subjects for our study are plants and the factors which influence the growth of plants. The chief of these are the soil, water, Fis. 2. Mushroom light, and heat.

Name four typical plants; four typical animals. In what way are plants like animals? How are they different?

Why must animals move to get their food?

How do plants get their food?

Name some plant that is not typical. Why is it not typical?

\section{KINDS OF PLANTS}

There are more than 300,000 kinds of plants in the world. They are divided into five great groups:

I. Seaweeds. The simplest plants form a group called seaweeds, most of which live in water. All other plants are descended from these. They have no distinct leaves, stems, and roots, but do contain chlorophyll. Many of them are food for fish.

2. Fungi. The fungi differ from scaweeds in not containing chlorophyll. They must get their food as animals clo, from other plants or animals. Some of them, as the mushrooms, get their food from the remains of deat things. But many of them, called para- 
sites, live on other living plants. Some of these do great damage. The worst Philippine parasite is the coffee rust.

3. Mosses. Mosses are unimportant plants descended from seaweeds.

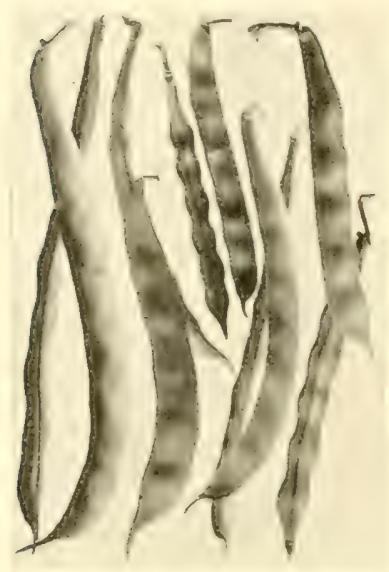

IFIG. 3. Phaseolus vulgaris, or white American bean

4. Ferns. Ferns are beautiful plants, descended from the moss group. They have roots, stems, and leaves, but do not form seeds.

5. Seed Plants. Plants having flowers and seeds are called seed plants. In this group are the most important plants, and almost all the cultivated plants, including trees, ornamental plants, and all food plants.

Scientific Names. Each kind of plant is a species, and has a Latin name. This name is made of two parts - a genus name, and a species, or specific, name.

A plant has a genus name, just as a person has a family name, and a species name, just as a person has a given name. Thus each plant in the Phaseolus genus is called Phascolus. Then, to distinguish a plant from others in the same genus, a species name is added. Among the plants of the Phaseolus genus, for instance, are the mungo, the patani, and the white American bean. They are called Phascolus Mungo, Phascolus lunatus, 
and Phascolus aulgaris. The genus name is always written before the species name. The name of the mushroom shown in Figure 2 is Agarious Merrilli.

\section{THE USES OF PIAINTS}

Food. The study of plants is more fundamentally important to us than is any other subject of study. For our greatest want is food, and all our food, except water

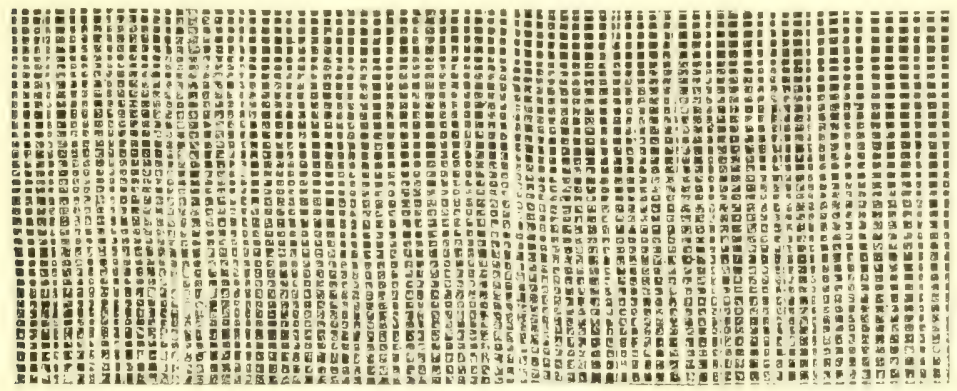

Flix + Sinamay

and salt, is furnished by plants. If we eat meat, or angs or fish, we are still dependent on plants, for they nourish the animals we eat.

Fuel. We are equally dependent on plants for our fuel, used for warmth, cooking, or lighting. This is still true even if we burn coal, for coal is made of the remains of plants which lived long ago.

Clothing. For most of our clothing, also, we are dependent on plants. The most important of the textile materials is cotton; others are hemp, flax, piña, and abacá. 
Building Materials. Plants furnish our most useful building materials. While some houses have stone walls, and roofs of tile or iron, these materials are not nearly so much used as lumber. Many houses in the Philippines are built entirely of nipa, bamboo, and rattan.

Medicines. Most of the medicines are furnished us by

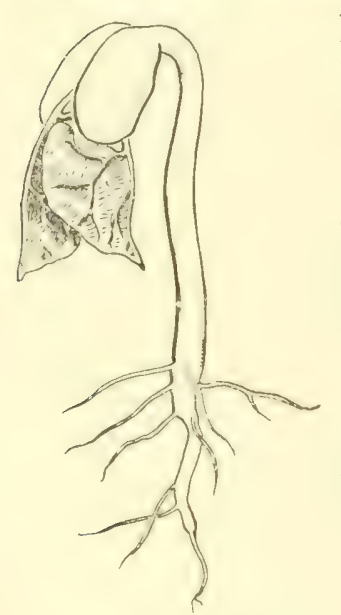

Firs. 5. Seedling bean,

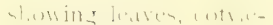
dons, stem, and root plants. A book about Philippine medicinal plants has been written by Dr. Pardo de Tavera.

Plants furnish us many other useful substances, such as rubber, gutta percha, resins, and most kinds of wax, and gums.

Soil enriched by Plants. Plants also improve the soil. Most plants cannot grow where plants have not grown before. The finest soil is where many plants have lived and died and decayed.

Beauty of Plants. Plants make beau tiful the places where they grow, and beauty has very real value.

THE PARTS OF PLANTS

The Root. The first part of the plant which comes out of the seed grows downward. This part of the plant is called the root. The function, or work, of the root is to fasten the plant securely in its place, and to take from 
the ground both water and substances which are dissolved in the water.

The Shoot. The part of the plant. which starts upuard from the seed, and usually grows in the air, is the shoot. The shoot is composed of stem and leaves. The stem is the axis of the shoot. The stem of a large plant, such as a tree, is composed of the trunk and the branches. The functions, or duties, of the stem are to hold the leaves where they will be exposed to the light, and to carry substances between the roots and the leaves. Stems are made up of nodes and internodes. The nodes are the places where leaves and branches come out of the stem, and the internodes are the parts of the stem between the nodes.

Leaves. In general, leaves grow in such

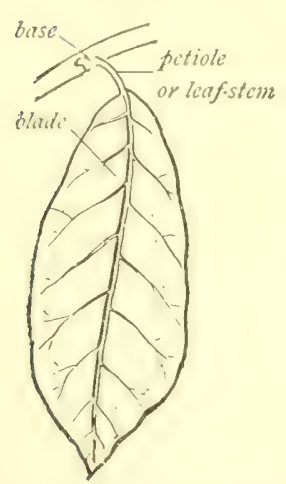
a position as to receive the most light. Leaves are very important parts of the plant, for in them the raw substances taken from the ground and

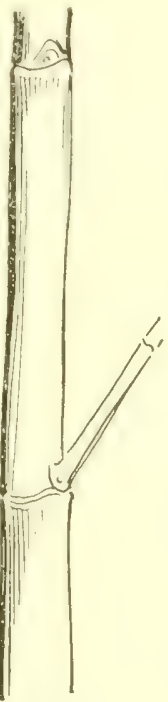

Fis $: 6$.

Stem of bamboo showing nodes and internode the air are made into useful foods for the plant. The parts of a leaf are the base, the petiole, or leaf-stem, and the blade.

Vegetative Parts. The stem, leaves, and roots work together to secure and FIG. 7. Parts of a leaf store up food, and thus to build a strong, healthy plant. They are called its vegetative parts. 
Reproductive Parts. A plant has also reproductive parts, whose work is the production of young plants. These reproductive parts are the flowers, fruits, and

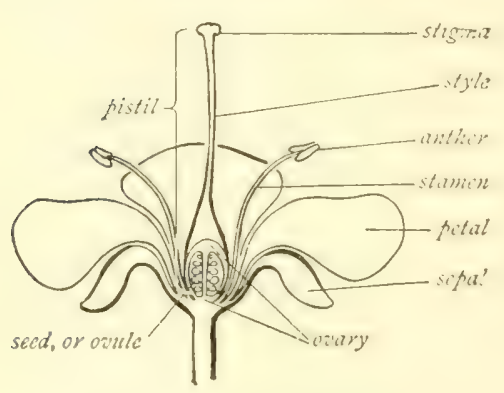

Fic. 8. P'arts of a flower seeds. One of the parts of a perfect flower is the ovary. The ovary contains ovules, and each ovule contains an egg, which can grow into a plant like its parent. When the egg has grown for a little while, its growth ceases, and the coats of the ovule harden around it; we then have a seed. While the ovules are thus changing into seeds, the ovary surrounding them develops into a fruit.

Find the ovules in the flower on patani, and show by a series of young fruits that these ovules become the seeds. Draw the different stages.

Name fifteen cultivated plants, and tell for what each is useful.

Name three plants cultivated for their roots; three cultivated for their stems; three, for their leaves; three, for their fruits; three, for their seeds.

What parts of the pineapple plant are valuable? For what are they valuable? What parts of the coconit tree are useful?

What do you think is the most important Philippine plant?

Name two Philippine medicinal plants, and give their uses. 


\section{CHAPTER II}

\section{THE SEED}

Parts of the Seed. A seed is a reproductive structure, composed of the embryo, seed coats, and sometimes an endosperm.

Embryo. The embryo in the young plant, in the seed. Its parts are the radicle, the cotyledons, and the plumule. The radicle becomes the root of the plant, and the plumule becomes the shoot.

Seed Coats. The seed coats consist of an outer coat and an inner coat, and are to protect the embryo. The outer coat, called the testa, is always hard; the inner coat is called the tegmen. In some seeds the inner and the outer coats cannot be sepparated. There is a hole through the seed coats called the micropyle, by which water can enter

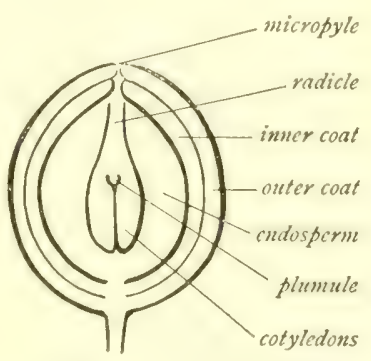

FIG. 9. Parts of a seed the seed. Through this hole the radicle comes when the seed germinates, or begins to grow.

Endosperm. Sime seeds, such as the seed of the coconut palm, and of maire, contain a store of food outside the embryo, but inside the seed coat; this part of the seed in called 
an endosperm. Many seeds contain no endosperm; such seeds have their food stored in the cotyledons. Squash and bean seeds have no endosperm.

Germination of Seeds. If seeds are dry, they can remain

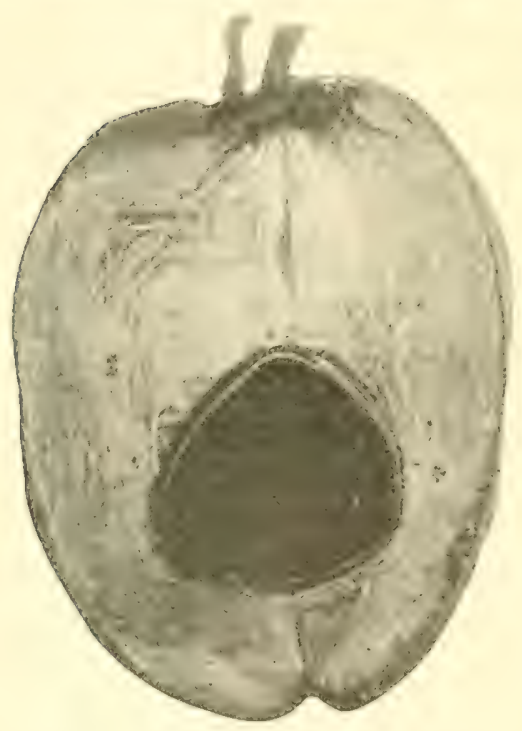

FIG. IO. Split coconıt showing fruit coat, or husk alive for a long time, but when they are moist, they must either germinate, or die and decay. A seed can germinate only when it has moisture, air, and a proper temperature. Enough air is dissolved in water to permit some seeds to germinate if they are under water, but most seeds will decay if they are kept there long. A seed is more likely to germinate in moderately cool than in warm water.

Kinds of Seeds. There are as many kinds of seeds as there are kinds of flowering plants. Related plants usually have similar seeds and fruit. All the plants whose seeds have one cotyledon are called monocotyledons; among these are rice, maize, cane, gabi, abacá, and palms. Plants whose seeds contain two cotyledons are called dicotyledons; anong these are beans, squashes, tobacco, coffee, and many other plants. Ferns are without seeds. The largest of all 
seeds is the coconut. The Bigr Trees of California have seeds so small that 500,000 of them weigh only one kilogram; but a tree grown from one of these seeds may weigh a thousand tons.

Study of Squash Seed. Fxamine a spurath seerl, noting its shape. Traw the seed. In the sharper end is a small hole, the micropyle. Carefully remove the testa, or outer coat. The thin, greenish inner coat, the tegmen, may then be seen. Remove the tegmen; what is left is the embryo. Its sharper end is the radicle. 'Two fleshy cotyledons make up the most of the

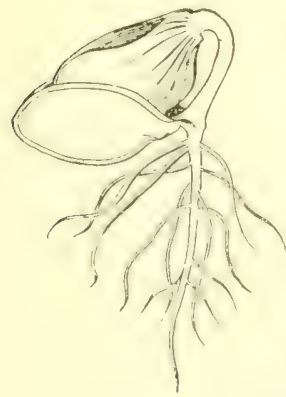

FIG. 12. Germinating squash seed embryo ; they are attached to the up-

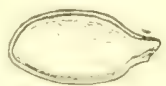

Ficr, Ir. Squash seed per end of the radicle. Between the cotyledons, at the base, is a small, triangular structure, growing on the top of the radicle; this is the plumule.

Germinate squash seeds on moist paper, or in sand or sawdist. What part is first to come out of the sced? Where does it come out? In what direction does it grow? Plant some of the seeds in sand, sawdust, or earth. What parts appear first above the surface? 'Try to germinate seeds under water; what happens? Let the sand in which some are germinating become dry; what happens?

Study of the Bean. Study a bean in the same way. Are the seed coats separable? Is the embryo straight? Do the cotyledions of all seeds appear above the ground?

Study of Coconut Seed. Remove the husk and hard shell of the coconut; what remains is the seed. The seed coats are thin and inconspicuous. The meat of the coconut, which, when dried, is copra, is a part of the en-

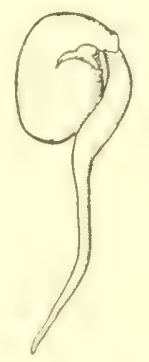

FIG. I3. Germinating bean dosperm; the water insicle the meat is also a part of the endosperm. Embedded in the meat, under one of the three eyes, is the embryo. Split it. The end next the shell is the radicle. The other end is the 
single cotyledon. Embedded in it, pointing toward the inside, is the plumule. This cannot be seen plainly until the seed begins to germinate.

Germination of Coconut. When the coconut germinates, the embryo elongates, pushing out through the eye,

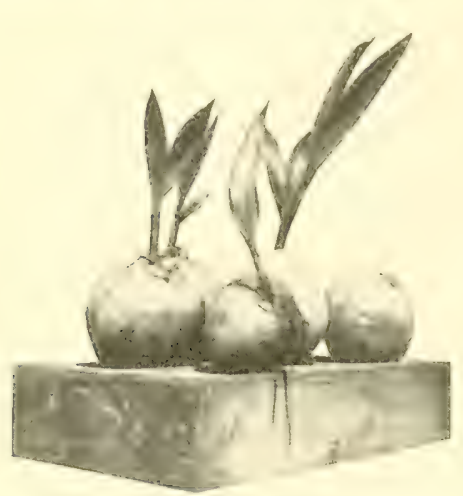

FIG. 14. Sprouting coconuts ready for planting and bending downward. After the roots become several centimeters long, the plumule breaks out through a slit in the embryo, just below the shell, and grows upward. The inner tip of the cotyledon enlarges, and becomes a porous body, called a foot, inside the meat, from which it extracts food for the young, growing plant.

Draw a coconut seedling, with half of the shell and meat removed.

What is the taste of the foot? What gives it this taste?

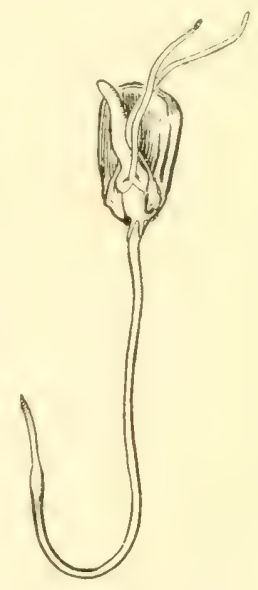

FIG. 15. Germinated maize

The Fruit Coat. The husk of the coconut is the fruit coat. Many seeds are even more firmly united to the fruit coats than is the coconut. This is true of maize and other grains. 
Study of Maize and Castor Bean. I hineret ani lerminate some seeds of maize. Is maize seed more like the squash seed or the coconut? Study the castor bean in the same,way. How does it resemble the coconut? How is it like the squash seed?

Fruits. A fruit is the entire reproductive structure dereloped from a single ovary. A fruit may contain one seed, or̈ few seeds, or many seeds. Most fruits which contain a single seed do not set it free, but instead of

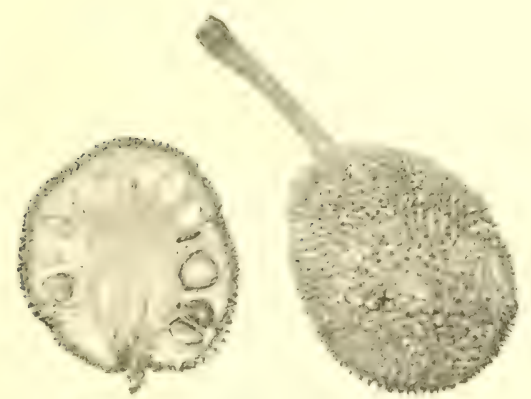

Fic. I6. Jack-fruit showing seeds

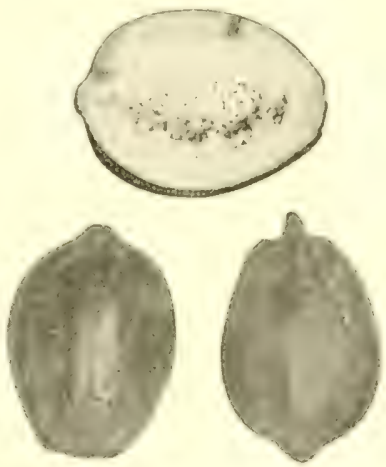

FIG. I7. Papaya showing seeds

this the whole fruits are scattered and planted. All grasses and many weeds have such fruits. The grass family includes bamboo, and all grains. Many-seeded fruits scatter their seeds in various ways.

How are the seeds of eggplant scattered? Of cotton? Of castor bean? Of papaya? 


\section{CHAPTER III}

\section{THE SOIL}

Any part of the surface of the earth in which ordinary

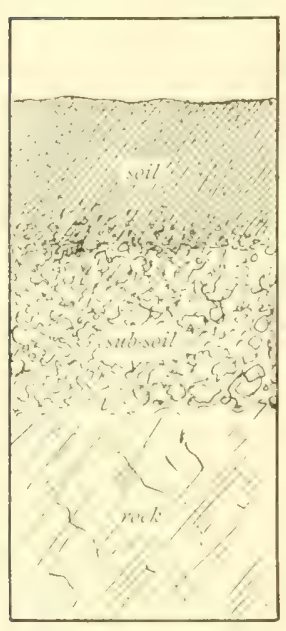

FIG, I8, Diagram showing the positions of soil, subsoil, and rock plants may grow, or which can be made fit for crops, is called soil.

The larger part of the earth's surface is water; ordinary plants cannot grow in the sea, which of course is not soil. Some of the earth's surface is solid or broken rock; this part, likewise, is not a fit place for ordinary plants.

Rocks are under all soils, everywhere; but soils vary greatly in depth. Soil in level places is usually deeper than on mountains, because the soil washes from the mountains to the valleys.

THE ORIGIN OF SOIL

Weathering. In all towns in the Philippines there are old stone buildings or old stone walls. On these, and in the cracks between the stones, plants are growing; so there must be soil here. But on a new wall or a new building we can find no plants and no soil. 
As the wall grows old the softer parts and the more exposed parts begin to disintegrate, or wear away. The wearing away is due to the "weather," and therefore is called "weathering."

This "weather" which can disintegrate rocks is made up of three factors: the moisture, the wind, and changes of temperature. The most active of these factors is the moisture. Some of the soil formed by weathering blows away as dust, or washes away and becomes mud. Some remains on the walls and is the soil in which we see the plants growing.

How old must walls be before plants grow on them? Will this happen sooner in dry or in moist places?

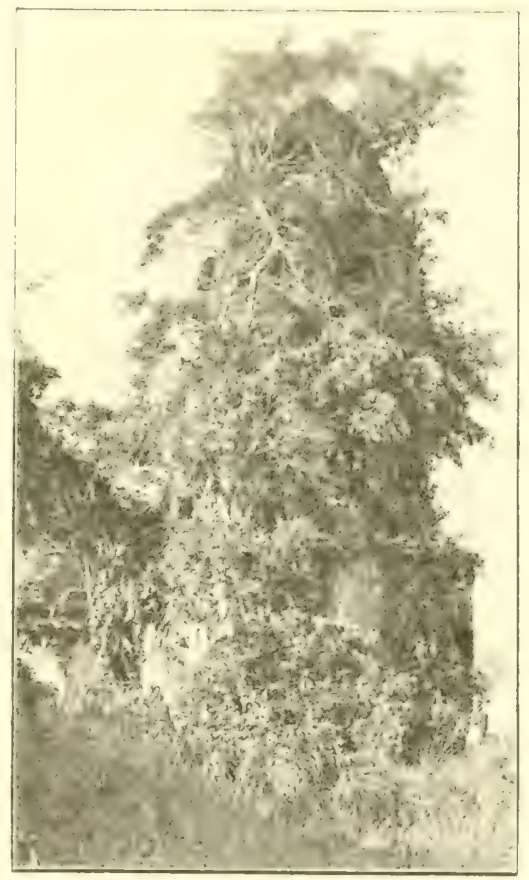

FIG. I9. 'lower of church at Daraga, Albay, ruined by eruption of Mayon in I8I4, now overgrown with plants

Formation of Soil. All the land surface of the earth came originally from beneath the sea, and was once solid rock. Just as stone walls are made by the weather into places where plants can grow, so the exponed part of this rock is made into soil. In the disintegration of 
the rocks of the earth, running water also is very active. In cold countries, ice has helped to do this work.

As is true of walls, some parts of rocks are softer than others, and disintegrate more quickly. Most of the hills

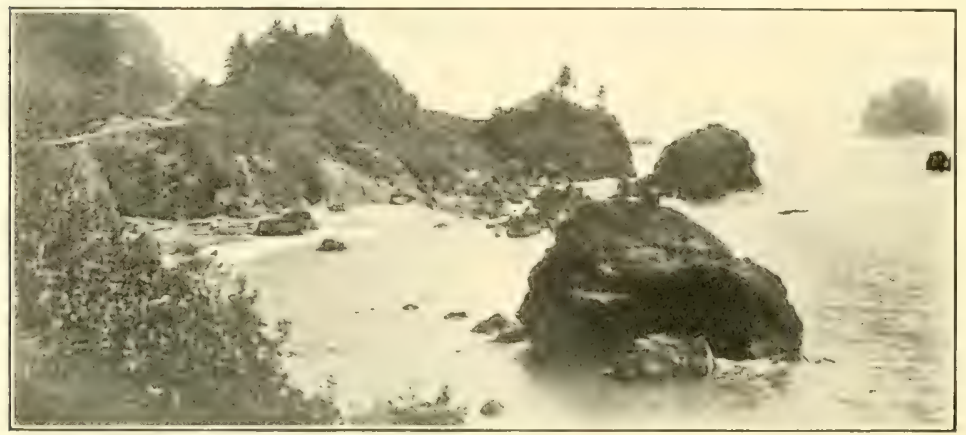

FIG. 20. Rocks standing out of the sea on the coast of Northern California

and mountains in the world are the hard spots which have been left, while the softer places around them have worn away.

KINDS OF SOIL, BY ORIGIN

Residual Soil and Loess. While the soil was forming from the rocks, some of it was carried away, and some remained at or near the places where it was formed. The latter kind is called residual soil. Some fine soils are so light that the wind can carry them as dust. Soil formed by the settling, or deposition, of fine particles from the air is called loess; it is usually a very compact soil, because it is made up entirely of fine particles. Dust blown into the air by volcanoes sometimes settles as loess. 
Alluvial Soil. Mrost of the soil which mores from one place to another is carried by running water. Even the clearest creeks and rivers always carry some of the land with them. When there are storms, a great deal of water runs from the land, and the soil carried with it makes the stream muddy.

In the mountains, rivers run so rapidly that they can carry not only mud, but even large stones. When they reach more level land, where they flow more slowly, the stones are left. Lower down, where the water runs still more slowly, it loses the gravel; and then the sand falls to the bottom. The finest particles of the soil are carried on, and sink to the bottom

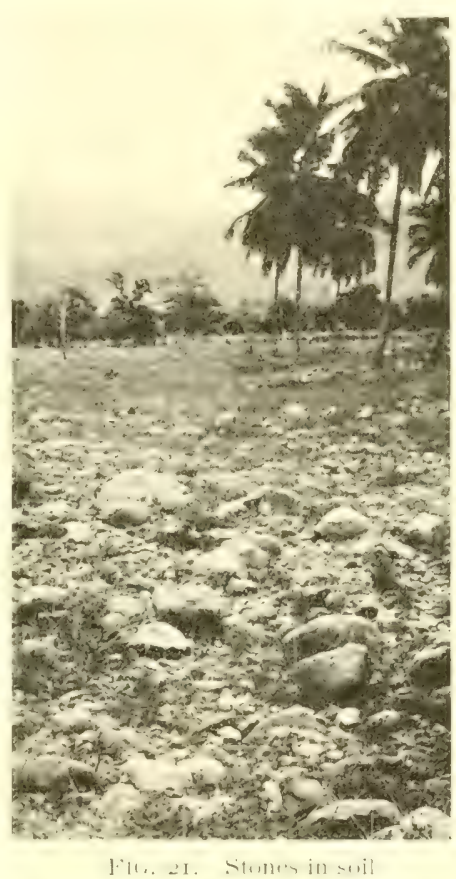

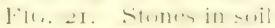
of the still water at the rivers' mouths. In this way deltas are formed.

Soil deposited from water is alluvial soil. Alluvial soil is usually fine and uniform. It is provided with all the fouds of plants, and is easy to cultivate because it is level. The level land near Manila Bar, and almost all other level land in the Philippines, is alluvial. 
Mold. When plants and animals die, their bodies become a part of the soil. Where vegetation is very dense, as it is in heavy forests, a large part of the soil is formed in this way. Soil formed mostly by the decay of plants and animals is called mold. Mold is always a

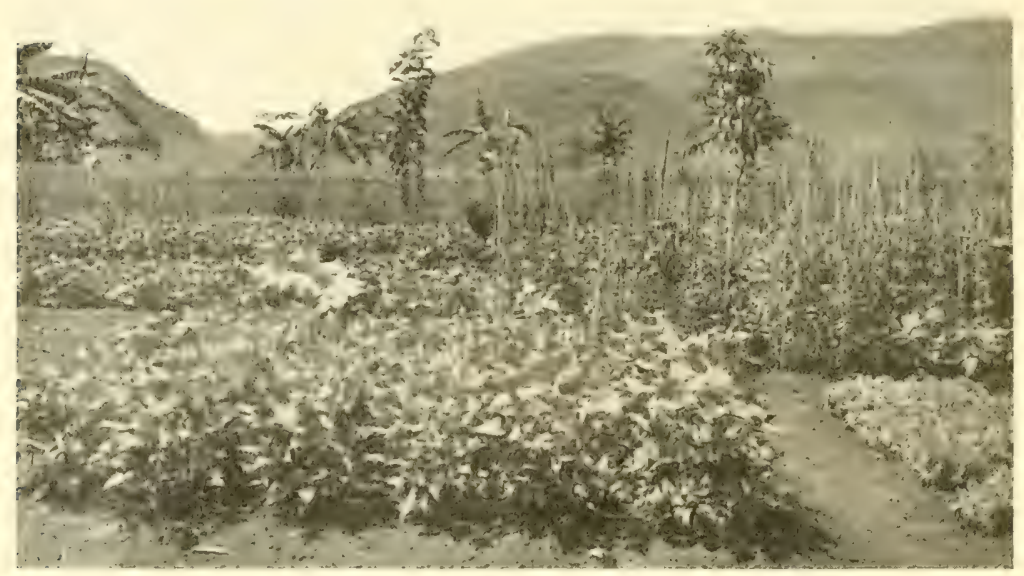

FIG. 22. Fertile alluvial soil in a valley

rich soil, because it is made up of what has alreaciy been plant food.

Humus. In marshes the organic matter - the bodies of plants and animals - sometimes cannot decay, because there is no air in the soil. Such soil becomes sour, and therefore useless. A soil which is sour because it contains much insufficiently decayed matter is called humus.

Most plants cannot live in sour soil; but if humus is well aired, it will become an excellent place for them. 
Putting lime on it also will make it fit for plants to grow in.

THE STRUCTURE OF SOIL

Qualities of good Soil. In oreler that plants may grow . well, it is most important that the soil shomld have the power to hold water. It must also be well aired, and must contain the foods that plants require.

Weigh exactly a kilogram of moist soil. Spread it out on a paper or board in the sun, taking care that none is lost. When it is as dry as it will become, weigh it again, and so learn what per cent more of water was in it than is in air-dry soil. Dry it in or on a stove, and weigh it again. Its further loss of weight shows that air-dry soil is not really dry. Put it in the sun for two hours, and weigh again. It is now heavier, which shows that really dry soil can take up moisture from the air.

Make these experiments with sand and with clay, and compare the results.

Note the area of the surface of a potato. Dip it into water, and, after shaking off all the water possible, weigh it. Cut it in two. Is there more potato than there was before? Has it now more surface? Dip it into water, shake it well, and weigh it again. Cut each piece again and again, noting the effect on the area of the surface, and on the power to hold water. If this experiment is well made, it will prove that:

(a) The smaller the pieces are, the greater the surface is in proportion to the mass.

(b) The greater the area of the surface, the more water can be held. These conclusions are as true of the soil as they are of the potato.

KINDS OF SOIL, BY STRUCTURE

Sand and Gravel. I soil of which as much as to per cent is made of particles as larege as 0.025 of a millimeter in diameter is called sand. Sand is the coarsest agricultural 
soil. Gravel is made of still larger particles, but it is hardly fit for plants to grow in.

Loam and Clay. A soil of which between 20 per cent and 40 per cent is made of particles as large as ' $0.025 \mathrm{~mm}$ in diameter' is called loam. Alluvial soil and mold are usually loam.

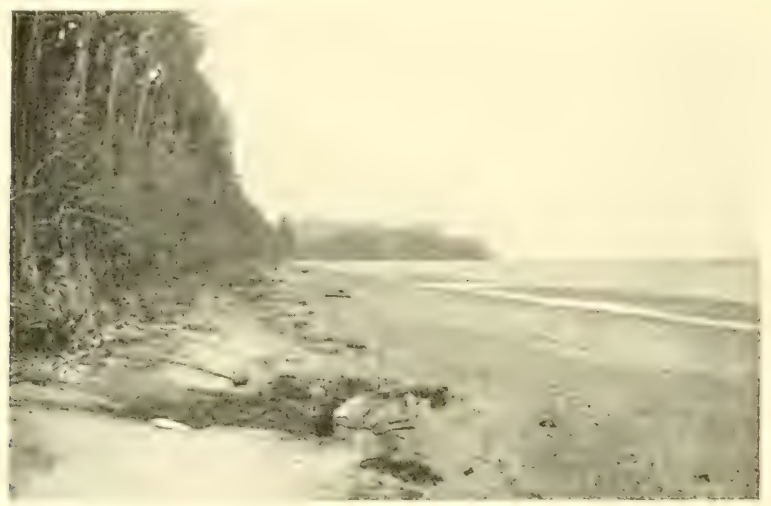

FIG. 23. A sandy beach on the coast of Luzon near Atimonan, 'Tayabas

Nost soils of which less than 20 per cent is made of particles as coarse as $0.025 \mathrm{~mm}$ in diameter are clay.

Take half a kilogram of each of these soils, air-dry. Let each stand overnight in water. Carefully pour off what water will run off, and then weigh the soils. How much water will each now hold? In the previous experiment with sand and clay, which held more water when air-dry?

Soil and Water. You have already learned that the finest soils will hold the most water. The water which sand can hold is less than 25 per cent of the weight of the sand. Loam can hold 25 per cent to So per cent 
of its weight of water; and clay can hold more than 80 per cent.

When a soil takes up as much as so per cent of its weight of water, the water often completely fills the spaces between the particles of soil, driving out all the air. The roots of most plants cannot live in a soil without air. Therefore, clay is a difficult soil for plants to grow in.

What is the origin of the soil in your garden? What is its structure (sand, loam, or clay)? Why is loam usually a better soil than clay? Why better than sand? At what time of year is sand likely to be best as a soil ? Do you know any wild plants that grow only in sand? 


\section{CHAPTER IV \\ THE FOOD OF PLANTS}

Need of Abundance of Food. If a plant has no food or has too little food, it starves to death, just as we should do. But the least quantity of food which will keep a plant alive is not enough to make it grow, and if a plant does not grow, it is of no value to agriculture. Nor is mere growth all that is needed. Agriculture is not profitable unless the plants raised grow thriftily and rapidly. They cannot do this unless they have a great deal more food than would keep them alive and let them grow a very little. Hungry plants, like hungry men, are poor workers.

Importance of Variety of Food. Plants are also like animals in needing sereral kinds of food. Men need to eat some salt; if they did not get salt, by itself or in other food, they would die. But if they got sait and no other food, they would still more quickly starve to death.

Rice is the principal food of nearly all Filipinos, but all Filipinos know that they cannot live on rice alone. Plants have many foods which are so absolutely necessary that if any one is entirely wanting, the plant must die.

\section{CHEMICAL ELEMENTS}

Composition of Substances. Nearly all the substances we see in the world are combinations of simpler sub- 
stances. Thus, the air is a mixture of gases, among which are oxygen, nitrogen, and carbon dioxid. The first two of these are simple substances, but the last is itself a combination of oxygen and carbon. Water is a combination of two simple gases, oxygen and hyologen. The bodies of living thing are excecelingly complex combinations and mixtures.

Elements. Simple substances, that is, substances which cannot posibly be divided so as to give parts of different linds, are called elements. Irom, gold, silver, and copper are simple substances. About seventy elements make up the world, and everything on it, as well as the sun, moon, and stars.

Elements Essential to Plants. ()f the serenty elements, there are ten, without all of which no green plant can live. These are carbon, nitrogen, hydrogen, oxygen, sulphur, phosphorus, iron, calcium, magnesium, and potissium. Fungi can live without two of the ten needed by green plants-calcium and iron. Besides the ten elements mentioned, animals must also have chlorine and sodium.

The Organic Elements. Carbon, nitrogen, hydrogen, and oxygen make up a very large part of all living things, and are therefore often called the organic clements. Beside these four, sulphur and phosphorus are part of the living substance itself, of all living things. The uses of the individual elements are not well known.

Calcium, Iron, and Potassium. Without calcium, plants cannot move food from the leaves to the stem and roots; so these parts may stare and die, though the leaves may 
be full of starch. Iron is a part of the chlorophyll; so plants without iron become white, and die because they have no chlorophyll to absorb the light. One use of potassium is to keep plants stiff and fresh by helping them to hold water; wilted plants cannot grow.

How Plants obtain the Elements. Plants can take up none of these clements, except, perhaps, oxygen, by themselves, but must receive them in combinations. The most important of these combinations is water, from which plant obtain hydrogen, and perhaps oxygen. Carbon is obtained from the carbon dioxid in the air.

The other combinations which supply plants with food are called salts. The salts dissolve in water, and plants take them up with the water in which they are dissolved. Although nitrogen is a gas, making up a large part of the air, plants cannot use it as a food in this form; their nitrogen must be in the form of salts, disisolved in water, which the roots can get. The water dissolves all these salts from the soil. Therefore, soil which is without any of them cannot support plants.

Elements usually Abundant. Except, rarely, in the case of iron, without which the younger leaves are white instead of green, it is impossible to know from a plant's appearance that it is in especial need of any one food. The only way to determine this is by experiments, as described on page 29. But most of the necessary elements are so abundant everywhere in the soil that plants never suffer for them.

Magnesium, iron, and sulphur are not present in large 
quantities in most soils, but plants need rery little of these, and practically alway havesufficient. Plants need much calcium, but most soils contain much of it. Sugarcane is the only important I'hilipprine crop likely to need more calcium than is present in the soil.

\section{FERTILIZERS}

Calcium. Substances containing plant food, which are added to the ground to make it more productive, are

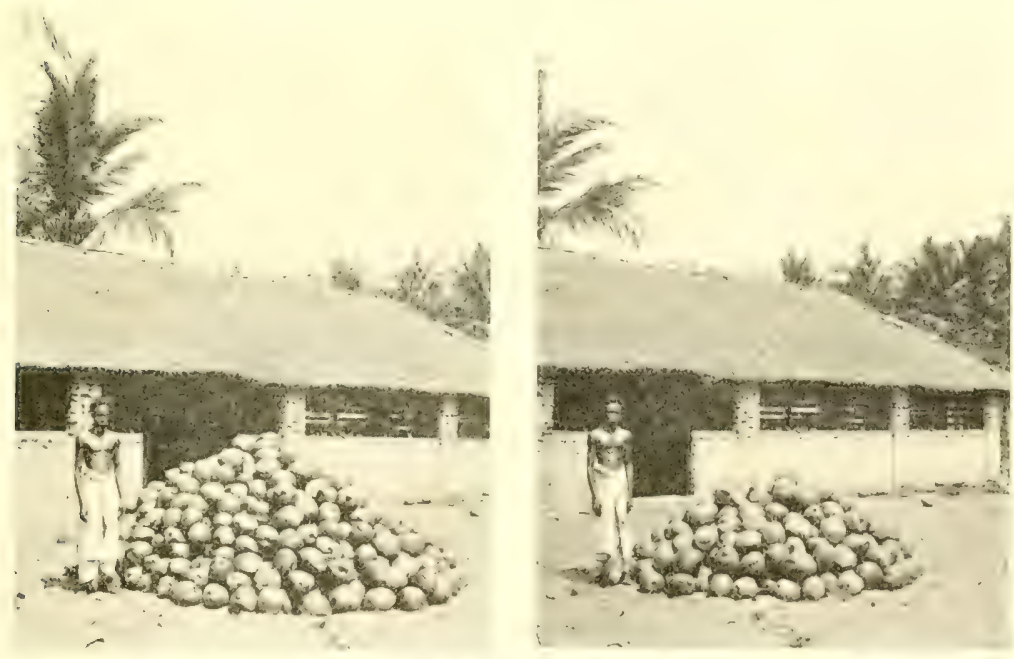

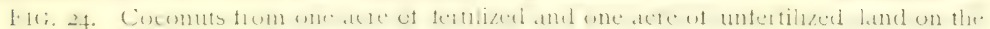
Loxton and Palmlands Estate, Cevion

called fertilizers. Ground which has been producing sugar for many years is often very weak in calcium. If limestone or coral, which contain much calcium, be crushed and put on the gromed, there will be a greater yield of sugar; the limestone or coral is a fertilizer. 
Nitrogen, Phosphorus, and Potassium. The elements of which agricultural soils are likely to contain less than plants need are nitrogen, phosphorus, and potassium. Therefore, these are the ones which should be used in fertilizers. Sometimes all three of these are needed, but usually some one is needed more than the others. Some fertilizers contain all three, and other foods besides, while other fertilizers contain hardly any of more than one.

Decaying vegetation contains all the foods of the plants that are decaying, and is therefore sure to contain some of whatever foods are most needed by any plant.

Manures. Stable manure also contains all the substances needed by plants, but contains more nitrogen than plants do, and is therefore an especially good fertilizer for general use. Poultry manure is especially rich in phosphorus. Because it is very soluble in water, poultry manure is a strong fertilizer, and plants are sometimes injured by too much of it.

Bat manure and bird manure, which are called guano when sold as fertilizers, are also rich in phosphorus. All of these manures contain considerable potassium also.

Bones and Ashes. Bones and fish-refuse are rich in phosphorus. Ashes are usually rich in potassium, which is called potash when used as a fertilizer. When a plant is burned, the hydrogen, carbon, and nitrogen go into the air, leaving all the other foods in the ashes. Ashes are therefore an excellent fertilizer for plant which are not in especial need of nitrogen; but for plants which need this substance, they are useless. 
Bean Plants and Nitrogen. The plants of the bean family have small knotty and wartike growths on their roots. These growths are called tubercles, and are caused by very small germs, or bacteria. The tubercles are the homes of bacteria. Through the activity of these bacteria, nitrogen is taken from the air and stored in the tubercles. This is called "fixing" the nitrogen. When the plants die, a part of the nitrogen fixed in their tubercles remains in the ground and enriches it. If the living tops of these plants are plowed under, the soil is still more enriched in nitro. gen. Plants used in this way are called green manures.

Experimenting with Fertilizers. As has already been stated, we cannot tell positively from the appearance of a plant what fertilizer it most wants; but we can learn by an easy and cheap Fig. 25. Tubercles on the experiment. Suppose that we have a roots of a bean plant field of maize which is well cultivated and watered, but still produces small crops. Some fertilizer is almost certainly wanted; but we might lose considerable money by treating the whole field with a fortilizer not especially. needed.

So we mark off plots two meters square; and on one plot put one kilo of manure; on another; two kilos; on another, one half kilo of ashes; and on another, one kilo. Guano, fish, or fish-refuse, and bean or peanut tops can 
be used on other plots, if these fertilizers are available. The effects of the fertilizers on these little plots will show what one it will be

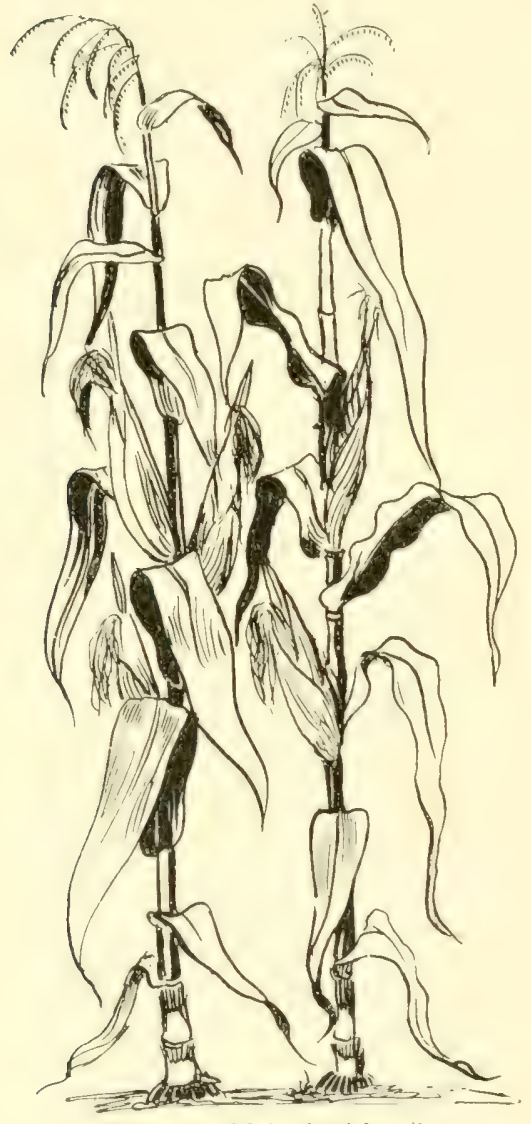

FIG. 26. Maize in rich soi! best to use on the whole field. Sometimes a mixture of fertilizers will give good results at the least cost.

The Caingin System. Since plants use up the food in soils, it becomes

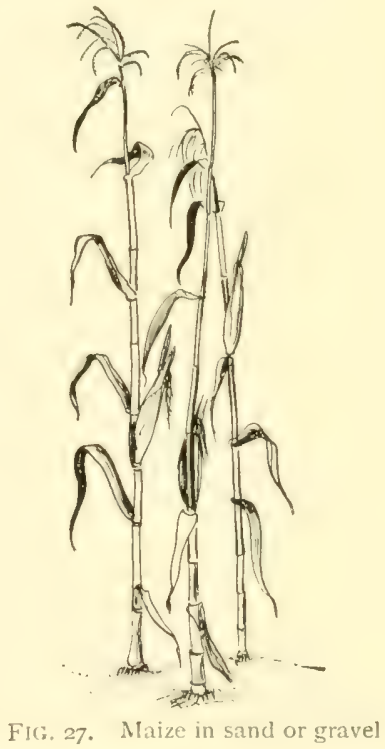

impossible after a time to raise good crops, without fertilizers, on ground which was once fertile. The caingin 
system of cultivation consists in clearing a new field whenever the old one ceases to yield well. This system is very expensive in the amount of labor required and very bad for the land.

Rotation of Crops. Inifferent crepes do not need the different foods in equal amounts. Therefore, a soil which will not produce more good crops of the kind already grown may still prove fertile, if a different crop is planted. It is good agriculture, when working with crops which do not live many years, to change the crop frequently on each picce of ground. A regular succession of crops chosen so as to prevent the exhaustion of any particular food from the soil, is called rotation of clops.

In the garden, fertilize one half of a plot of maize, and one half of a plot of some kind of bean, with manure, putting one kilo on each square meter. Leave the other half of each plot without any fertilizer. Cultivate the two halves in exactly the same way. Note the difference in the amount of the crop, and in the time it takes it to mature. This experiment should be made by the whole class rather than by the individual students. 


\section{CHAPTER T' \\ PLANTS AND LIGHT}

Chlorophyll and Light. We have already learned that the essential difference between plants and animals is that plants can form their own organic food by means of the light absorbed by the chlorophyll, while animals have not this power. Carbon dioxid and water are the substances from which the plant makes its food; and the first visible product of these in the plant is sugar or starch.

Value of Sugar and Starch. Sugar or starch is used in forming all the different parts of the plant. Without sugar or starch, no plant can grow, or even live. These products are equally important to men, for it is to secure one of these, or something made from it, that every plant is grown in agriculture. As these products are formed by the help of chlorophyll, and it is the leaves - the green parts of plants - that contain the chlorophyll, we know that they are the parts where the sugar or starch is formed.

Light Essential. If we cxamine any cultivated plant, we see that its leaves are arranged so as to receive all the light possible. Since plants can form sugar (or starch) only in the light, and have no value except when they produce it, and in general are worth more, the more of it they produce, it is very clear that good crops cannot 
be expected from plants that receive less light than they need.

Amount of Light Needed. The amount of light neerled depends on the kind of plant. All of our cultivated plants are deserended from uncultivated plants, and retain most of the characteristics of their wild ancestors. some of them demand all the smonlight posible. Among these are the cocomut and the plants of the grass family, such as rice, maize, and cane. Other plants grew in forests when they were wild plants, and do not usually thrive in very strong light. The reason for this is that their leaves, being large, cannot always be supplied with water; therefore, in dry or windy weather they become injured by dryness. I'lants of this kind must usually be protected by shade trees.

Shade-loving Crops. The principal shade-loving cropss of the Philippines are abacá, cacao, and coffece. It is only during the dry scasom, however, that too much light can injure these plants, and in places where there is no dry season they ought not to be shaded. In such places they are more productive, because they receive more light, and so can grow faster and stronger. In some parts of Mindanao, abacá produces a good crop when eighteen monthe old, and yieldes is piculs of fiber a year from one thousand plants. In places where abacá must be shaded, two years is an early yield, and $\mathrm{I} 2$ piculs a very satisfactory product. Coffee needs to be shaded in Batangas, but not in the highlands of Benguet and Lepanto. 
Tobacco is a plant which can well use all the light possible while it is zoung, but when it is older ought to be shaded to produce the finest leaves. It is the only plant on which light has any possible bad effect, except that of causing too great loss of water.

Distance between Plants. The distance by which plants ought to be separated is determined by their need of light. If placed too near together, the individual plants receive too little light, and usually grow tall and slender, and produce little or no fruit. A hektar of land will produce more fruit with a proper number of plants than with too many; so the added plants are worse than useless.

The influence of light on the production of fruit is illustrated by the coconuts at San Ramon, the government farm near Zamboanga. Trees in a dense grove bore less than $S$ nuts in three months; in a more open grove, less than II; in a double row along a road, 22; in a single row by a slough, 27; and a large tree standing alone bore 55. This is at the rate of 220 nuts a year for the solitary tree, probably ro times as many as for the trees in the denser grove.

At La Carlota, in Negros, 25,000 plants of purple cane on one hektar of land produced 6 picos more of sugar than did 30,000 plants on an equal area.

Weeds. Of course, anything which robs plants of light is very injurious. One of the ways in which weeds injure crops, in addition to taking a part of their food from the soil, is by taking a part of their light. There are no weeds in a good garden, and not many on a good farm. 


\section{CHAPTER VI}

\section{PLANTS AND WATER}

Piants need water for three purposes: for their supply of hydrogen, for use as building material, and as a source of mineral food.

Hydrogen. They get hydrogen from it. Plants must have hydrogen, and they can get it only from water. Next to carbon and oxygen, which plants can obtain from the air, they need more of hydrogen than of any other food.

Building Material. Plants require many times as much water for building material as for food. It must be in the cell-walls; in the living substance, the protoplasm; and in the vacuoles, which are the cavities inclosed by the protoplasm.

The water in the walls makes it possible for the substances clisiolved in the water to pass through the walls; if the walls were dry, the sugar formed in the leaves could not pass to other parts of the plant.

The activity of the protoplasm depends on the water in it. Seeds are inactive, because they contain little water; when they are wet, they become active and germinate.

The water in the vacuoles keeps the soft parts of plants, such as leaves and the tips of stems and roots, 
fresh and in the proper form. If the vacuoles lose much water, the plant wilts. Wilted plants cannot grow.

Mineral Food. Plants need water for the mineral food dissolved in it. Boil water from a well in a kettle for a long time, and you will find a lining or sediment in the kettle; this is made of salt which were in the water, and were left behind when the water evaporated. Water evaporates from the leaves of plants, and the substances dissolved in the water are left behind.

Transpiration. Evaporation from living plants is called transpiration. The water transpired by plants is many times as much as the water needed for building material. Except for their transpiration, plants would be practically unable to get their mineral food, however much of it there might be in the ground.

Transpiration takes place almost entirely from the leaves. If it is too active, the plants wilt, and wilted plants can neither grow nor make their food. If wilted plants continue to lose water too rapidly, they die. But so long as growing plants are able to get water as rapidly as they lose it, and so prevent wilting, the most rapid transpiration is the best; because the more rapid is the transpiration, the more mineral food is obtained. Surlight, wind, dry air, and warmth help transpiration. On the other hand, darkness, moist air, still air, and cold hinder transpiration.

The Transpiration Stream. The water transpired by the green, soft parts of the leaves reaches them through the veins and ribs. It comes to these through the petiole 
from the stem. The stem gets it from the big roots and these from their branch roots, and these finally from the young, newly grown parts of the finest roots. In the roots, stems, branches, petioles, and veins the water is always moving upward in the wood. This current of water is called the transpiration stream. The wood is a strand in the axis of each root. The water reaches the wood through the fleshy part of the root, from the epidermis, or surface layer.

Cut off a leafy branch or stem and put it in red ink. In what part (bark, wood, or pith) of the stem does the ink rise? Can you prove by this experiment that water moves through the veins of the leaves? How rapidly does water rise in the stem? This experiment will succeed best if the stem is cut under water, and put into the ink without letting it get at all dry.

Find the woody strand, and the soft part around it, in a coconut root. Old roots of coconut have also a hard shell, the hypodermis, which forms just inside the very thin epidermis, and kills

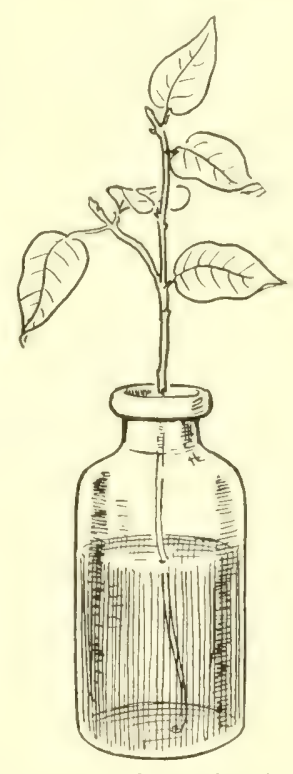

FIG, 28. Stem placed in red ink the latter. Where there is a hard hypodermis, water cannot be absorbed; there is no hypodermis near the tip of the root.

If coconut roots are not available, use betelnut.

\section{WATER IN THE SOIL}

Plants sometimes have so much water that it injures them, and sometimes they suffer because they cannot get enough. It is generally possible for us to remove some water if there is too much in the soil, and to fur- 
nish more if there is too little. Agricultural plants are damaged more by dryness than in all other ways together. Providing for their proper supply of water, if they have too little, is therefore the farmer's most important single task.

Effect of too much Water. We have already learned, in the chapter on the soil, that the soil is made of fine particles, each of which is surrounded by a very thin film of water. Between these particles, with their films of water, the soil

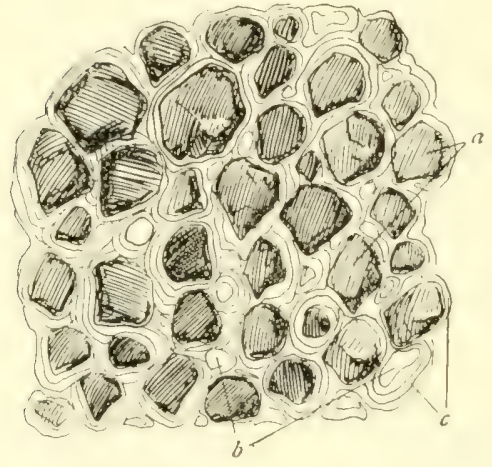

FiG. 29. Particles of soil (a) surrounded by air $(b)$ and water $(c)$ also contains air. Too much water in the soil displaces the air. The roots of most plants must breathe free air, just as we must, and they die if there is no free air in the ground, just as men drown if they are too long under water. The only Philippine agricultural plants which can live in soil full of water are rice and gabi. Cacao also can live longer than most plants without free air in the soil. If soil is too wet, it is usually easy to drain it by digging ditches for the water to run out. Ground which is always low and wet should be drained by permanent canals. Narrow, temporary ditches, quickly made and easy to fill up, often make it possible to use during the rainy season gardens otherwise too wet for any use. 
ABSORPTION OF WATER

Roots. Since the water in good soils is all in the membranes surrounding the soil particles, it is the water in these membranes which the roots must be able to take up. As a matter of fact, they are never able to take it all, but die from dryness while the soil still holds some water. To be able to take the water from the soil particles, the roots of the plants must come into contact with these particles as completely as possible. And since it is obviously the surface of roots which can absorb water, they need to have a great deal of surface. To get a great surface, and to reach all the soil particles possible, most plants have a great number of fine roots. By actual measurement, the total length of the roots of one squash

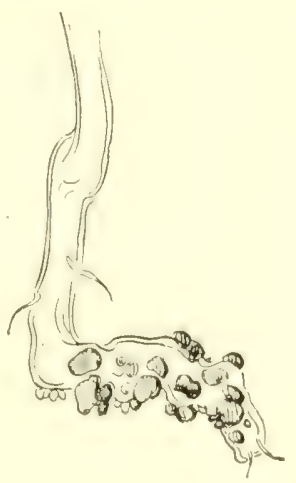

FIG. 30. Root hairs in contact with particles of soil plant was twenty-five kilometers. The coconut is notable for having few fine roots; yet one tree may have more than six hundred thousand absorbing tips.

Root Hairs. But even the finest roots of plants are usually not fine enough to keep plants well supplied with water, and so the roots have special absorbing structures, the root hairs. These are tubular outgrowths. each from a single epidermal cell. They have exceedingly thin walls, and so can grow into the finest chinks 
between the soil particles, and fit into their smallest unerennesses, instead of pushing eren the smallest particles aside, as the roots do when they grow through the soil. This makes them better fitted than the finest roots to take the films of water away from the particles of the soil. They also increase the absorbing area of the roots; the hairs give the roots of some plants as much as twelve times the absorbing surface the roots would have without them. The hairs are formed on the youngest parts that have stopled growing. They are short-lived, and so are not found on old roots.

Wash the soil very carefully from the roots of a young maize plant with roots not more than $10 \mathrm{~cm}$ long. The roots will be seen to have a felty covering made of the root hairs. A single root hair is often too small to be seen without a microscope.

Because the root hairs are so delicate, it is usually impossible to transplant a plant without breaking most of them. When they are broken, the plant is left without its absorbing structures, and even if the ground be very wet, the plant is likely to die promptly for want of water if it transpires actively. The transpiration of transplanted trees is often prevented by cutting off a large part of the leaves or branches. When garden plants are transplanted they must be shaded, if the sun shines. Within a day or two they proxide themselves with new root hairs, and the shade may be remored. Because the air is most moist at night, the best time of day for transplanting is late in the afternoon. Plants should be watered before and after transplanting. 
CONSERVATION OF THE SOIL WATER

Need of Conservation. In most parts of the I'hilippines the year is made up of a rainy season and a dry season. As much rain falls in a few months as plants necod cluring the year; and yet there are months during which they suffer from drought. It is the work of the good farmer to make the water last as long as possible. We have already learned that the finer the soil particles are, the more water the soil will hold. (rood cultivation breaks w) the soil into finer bits, and so makes it

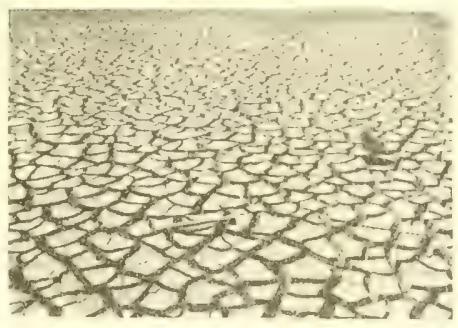

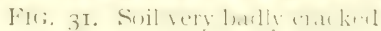
hold more water. In uniformly fine soil, water moves from one part to another much more readily than in coarse or irregular soil.

Effect of Careful Cultivation. There is crerywherand in the dryest seasons, water enough a short distance below the surface of the ground; but the hardness and coarseness of the ground kecp the routs from groing rery deep, and keep the water from moving upward. If the soil is cultivated and kept soft and fine down to where it is always moist, the water will constantly move upward to take the place of what is craporated (or taken wp) by plants. Therefore, deep cultivation lets plants grom in places where the ground would be too dry without it. In Manila, lettuce will grom well in february in finc 
ground cultirated $20 \mathrm{~cm}$ deep, if irrigated once in two weeks; better than in ground cultivated $10 \mathrm{~cm}$ deep, where it is watered every other day.

At the Spanish experiment station in Albay, it was found that during the dry season abacá grew better on land prepared with an American plow before the abacá was planted than it did where the Filipino plow had been used.

Although clay holds more water than sand does, it usually dries deeper in dry weather, both because it becomes hard in such large blocks that the water cannot move upward through it, and because it cracks badly.

Mulching. The water which is in the sroil when the dry season begins is lost by evaporation, either from the surface of the soil, or through plants. If all weeds are killed, the loss of water by their transpiration is prevented. The eraporation from the ground itself is made the least possible by leepoing the surface smooth and even, and very fine. This surface is sometimes called a "mulch." It is dry, and full of air; but the air is quiet, and does not move rapidly when the wind blows, as the air does in a coarse, or rough, or cracked surface. In the latter soils the air is constantly moving in and out, and carrying out a great deal of moisture. Therefore, cultivation, by making the soil fine, not only makes it receive water from deep in the ground, but prevents the loss of this water from the surface. At the San Ramon farm, a part of the abacá, which was planted in Spanish times, is no longer in rows, and so cannot be cultivated 
with cattle. In dry seasons this part is injured by drought, and finally becomes entirely unproductive a month sooner than does the cultivated abacá on poorer ground.

\section{IRRIGATION}

Various Methods. In spite of excellent cultivation, some lands are so dry, and some crops so dependent on

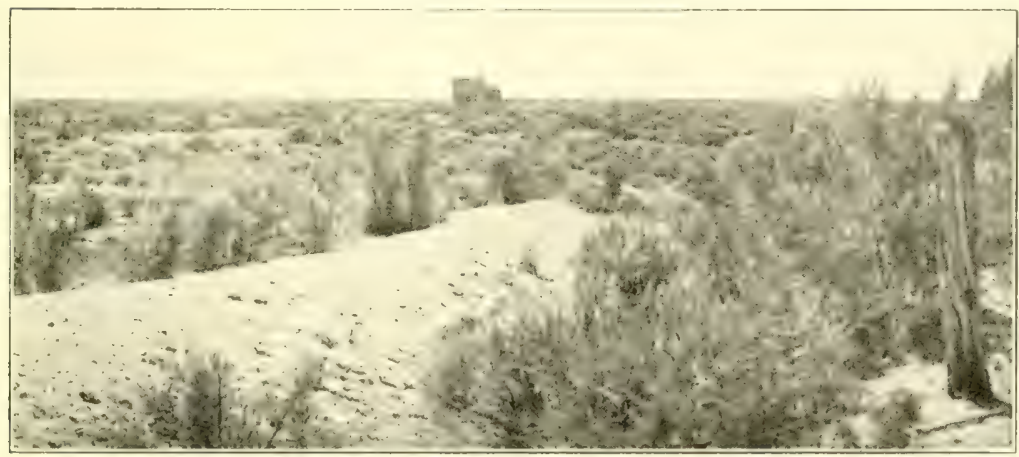

FIG. 32. Arid land in western America before irrigation

water, that their profitable cultivation depends on irrigation. There are various ways of putting water on land: by hand, by windmills, by engines, and by gravity. Human labor can be used only where a valuable crop can be raised on a little ground, especially in gardens. In these, the water should be put on the ground in the late afternoon. IVindmills, ton, are used only for irrigation on a small scale, raising crops so valuable that a man needs but little land. Steam pumps are used in the United States to irrigate great rice fields; but in the 


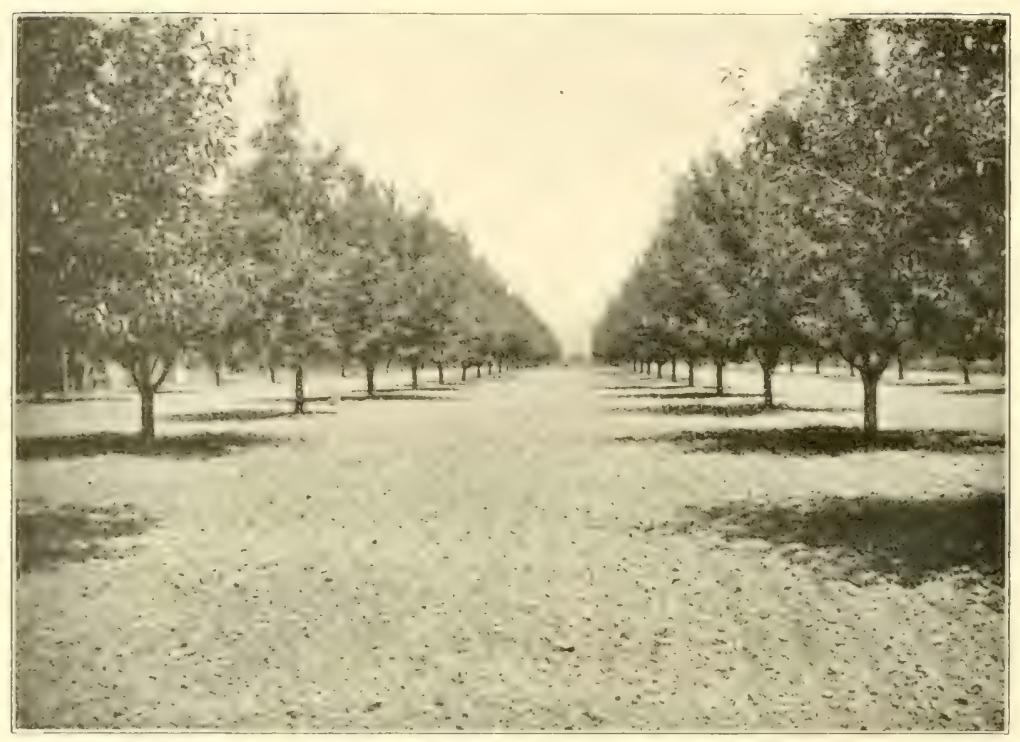

FIG. 33. The same land shown in Figure 32 after irrigation

Philippines they are used only near cities, and are not likely to come into general use.

Gravity. By far the cheapest irrigation is usually by gravity alone. The water is taken from a creek or river at some point high enough so that it will rum through a ditch or canal to the land to be irrigated. The canal should be kept on the highest ground possible, so as to have as much land as possible below it. If much land is irrigated, branch ditches run from the main canal, and are cut off by gates which can be opened and shut. In this way the water is turned into different fields at clifferent times. It is better to imigate fields thoroughly and 
not often, than to give them a little water frequently. If possible, land should be cultivated as soom after it is irrigated as it is dry enough. Ifter the ditches are dues and the gates are made, the only expense of this kind of irrigation is keeping the system in order. This is least expensive if the ditches are straight, and the water flows slowly. The very numerous rapidly falling streams make this kind of irrigation feasible and cheap on most of the good agricultural land in the Philippines.

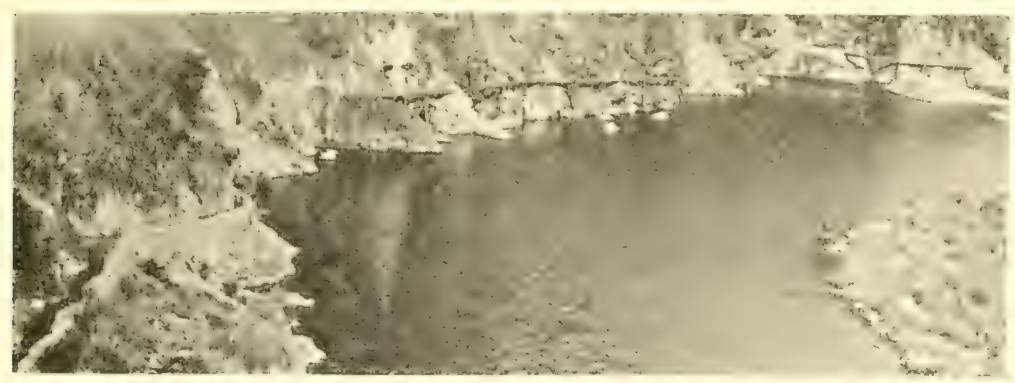

FIG. 34. Irrigation ditch and flume in Lepanto-Bontoc 


\section{CHAPTER VII}

\section{CLIMATE AND AGRICULTURE}

THE possibility of any agriculture, and the kinds of plants which can be raised, depend upon the climate. The chief factors of the climate are moisture and temperature. In some places, the wind also is important: all parts of the Philippines north of Mindanao are subject to typhoons, which are sometimes exceedingly destructive to crops.

Uniform Temperature. The torrid zone is characterized by a rather high and very uniform temperature, and heavy rainfall. Nearest to the equator, the temperature is in general most uniform, and the rainfall heaviest. The difference between the average temperatures of the coldest month and the hottest month of some Philippine towns is:
Tagbilaran, 2.1 ${ }^{\circ}$
Atimonan, $4.3^{\circ}$
Davao, $2.2^{\circ}$
Baguio, $4.5^{\circ}$
Cebu, $2.7^{\circ}$
Surigao, $4.6^{\circ}$
Kapis, $2.7^{\circ}$
Tarlac, $5.2^{\circ}$
Manila, $3.5^{\circ}$
Aparri, $6.5^{\circ}$
Iloilo, $3.8^{\circ}$
Batan Islands, $7.0^{\circ}$

The least known difference in the world is at Equatorville, on the Congo River, where it is $1.2^{\circ}$. At Hongkong it is $134^{\circ}$. 
It is the uniform temperature, not a high one, which characterizes lands close to the equator. The average yearly temperature is greater $15^{\circ}$ north, about the latitude of Manila, where it is $26.3^{\circ}$, than on the equator itself, where it is $25.9^{\circ}$. It must be because the temperature is not sufficiently uniform, that some plants. such as the mangesteen and durian, which are usually regarded as the two most delicious tropical fruits, do not grow as far north as Panay. Islands have usually a more uniform temperature than continental places.

The arerage temperature for a month is found by adding the temperatures of all the days, and dividing the sum by the number of days.

Advantages of the Tropics. No plant of agricultural value can grow and produce crops near the freezing point of water $\left(0^{\circ}\right)$, and many of them are killed by frost. For this reason, crops do not grow during the winter, where there is a winter; and there are only about four months during which the plants of temperate countries grow really actively. Frosts probably never occur in the Philippines except in the high mountains of northern Luzon. So far as the temperature is concerned, it should be posisible to raise in the l'hilippines two or more crops in a year, of most plants of temperate lands.

Light. The advantage of tropical countries in agriculture is even greater than the temperature shows; for they also receive more light, and so plants can form more organic food. 'The light at Pará, in Brazil, and at 
Kew, near London, was measured and compared in I 866. In April there was 20 times as much light at Pará as at Kew, and in August 3.3 times as much.

Rainfall Important. The amount of rainfall, and its distribution throughout the year, are more important than the temperature in determining what crops can profitably be grown in any place. A favorable temperature is plainly of no service where the climate is too dry to let plants thrive. Even without rain, a moist atmosphere is an advantage to plants.

Maguey and pina are the only Philippine crops which are very productive where there is not a heavy rainfall fairly erenly distributed through all the months. Other crops can endure a shorter dry season, and most of them can be kept in excellent condition if failure of rain is made up by irrigation. Abacá is injured by even a brief drought, but coconuts would probably thrive best with no rain at all, if properly irrigated. Sugar, rice, and maize want dryness as they mature.

Rainfall in the Philippines. There are great local differences, that is, differences between places near together, in the rainfall in the Philippines, and these determine what crops can be raised in the various sections. The rainfall at different places from September, I 902, through August, 1903, was as follows, the figures being the number of millimeters:

Masinlok, 3862.9

Borongan, 3452.7

Caraga, 3 I 65.2
Balanga, I 908. I

San Fernando de Unión, I 869.7 Surigao, I 7 I. 5 


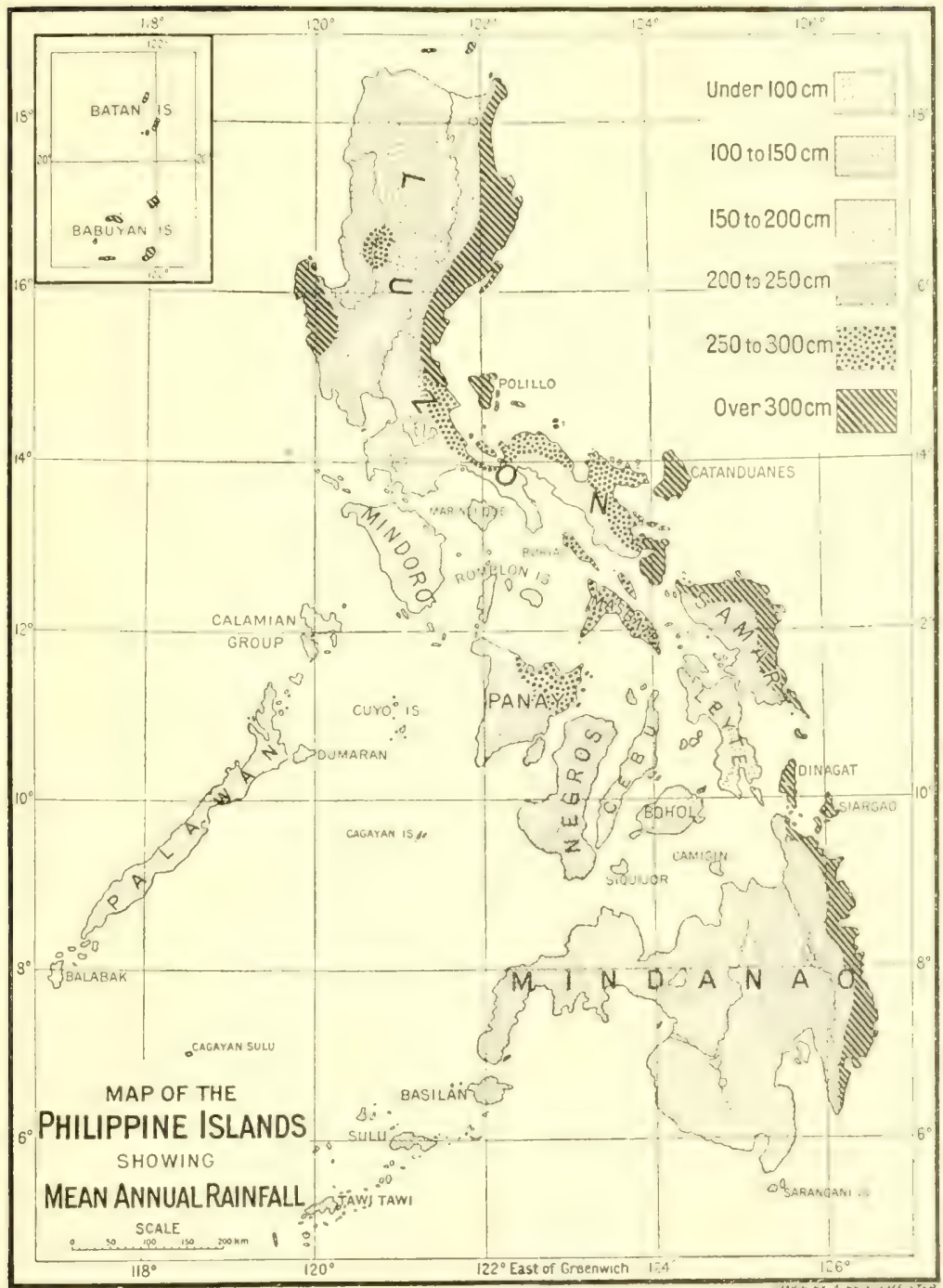

FIG. 35. Rainfall map 
Baler, 3008.4

Baguio, 2862.3

Candon, I 780.9

Kapis, 2788.7

Porak, I 757.9

Olongapo, 23 I 7.8

Aparri, i 7 ĩ 7.8

Tagbilaran, 2286

Dapitan, 1700.6

Vigan, 2207.9

Ormok, I699.5

Atimonan, 2 197.3

Marilao, I699.3

Dagupan, 2066.3

Bolinao, 20 I 9.7

Corregidor, I673.I

Cotabato, I 633.8

Legaspi, I 955

Iloilo, I 925

Manila, I 332.3

Davao, I 3 IO. 2

Cuyo, I 293.9

Tarlac, I 480.5

Jolo, I 438.4

San Isidro, I 354.4

Tuburan, IO49.I

Nueva Caceres, I047

Massin, 976.2

San José de Buenavista, I 258.9

Cavite, I I 02.6

Isabela de Basilan, I I00.5

Cebu, 9 6.6

Arayat, 761.7

Zamboanga, 4 I 3.4

These figures give a fair idea of the relative rainfall in different parts of the Islands. However, there is a rery considerable variation from year to year. In Manila, the average, from I 865 to I902, was I $938.3 \mathrm{~mm}$; the least being $906.5 \mathrm{~mm}$ in 1865 , and the greatest, $2978.8 \mathrm{~mm}$ in 1867 .

The rainfall can be measured roughly in a can fastened on top of a post in an open yard. It must be measured and the can emptied immediately after each shower. In some places vessels to measure the rainfall more accurately can be obtained from the Weather Bureau.

Dry Seasons. There is likely to be a destructively dry' season, in any year, on the west coast of the Zamboanga 
Peninsula, in Inticpte, in western Mindoro, and from Batangas to Ilocos Norte. In those parts of the Istands bordering on the Pacific Ocean, or not separated from it by mountains, there is very rarely an injuriously dry season. In Manila, on the average, So per cent of the year's rain fails in the five months from June to October.

Altitude and Rainfall. With altitude, that is, height above the sea, the temperature decreases, and the rainfall and the moisture in the air increase. The effect of the rainfall is seen by comparing that at a station of the Forestry Bureau on Mt. Mariveles, at 640 meters altitude, with that in Manila. The average rainfall at the foot of the mountain is practically the same as that in Manil?.

February, I 905

March, 1905 .

April, 1905 .

May, I905 .

June, I905 .

July, 1905

August, I 905.

September, I 905

Total, 8 months
AT 640 METERS

$2.2 \mathrm{~mm}$
$6.8 \mathrm{~mm}$
$273.3 \mathrm{~mm}$
$70.1 \mathrm{~mm}$
$1034.3 \mathrm{~mm}$
$1401.6 \mathrm{~mm}$
$294.6 \mathrm{~mm}$
$709.2 \mathrm{~mm}$

$3792.1 \mathrm{~mm}$
AT MINILA

$2.8 \mathrm{~mm}$

I. I 12111

I $73.8 \mathrm{~m} 1 \mathrm{~m}$

$24.0 \mathrm{~mm}$

$346.2 \mathrm{~mm}$

$594.4 \mathrm{~mm}$

$2 \mathrm{I} 2.8 \mathrm{~mm}$

$239.6 \mathrm{~mm}$

I $594.7 \mathrm{mnl}$

Altitude and Agriculture. Becallese of the altitude, coffee has been very profitable in Lipa and Alfonso, but 
never in Batangas or Naik. Coconuts do not usually thrive above 300 meters altitude. With the Igorots liv. ing above 1600 meters, millet takes the place of rice. The best camotes in the Islands grow at an altitude of more that I IOO meters; and the best cabbages, above 2 I00 meters.

Draw an outline map of the Philippines, putting in the places whose rainfall is stated in this chapter, and put in the rainfall of each.

Will abacá thrive better in Zambales or in Albay? Why?

Measure the rainfall in the school garien for a month, and then compute the average rainfall for that month. 


\section{CHAPTER VIII}

\section{THE LIVING ENEMIES OF CROPS}

Kinds of Plant Enemies. Almost all of the living enemies of plants are insects or fungi. Besides these there are birds which attack various crops, especially rice; bats, which eat fruit; and wild hogs and monkeys. The means of fighting these enemies are well linown, and do not need to be described here. There are also a few diseases caused by bacteria, which have never been studied at all in the Philippines; and a few diseases caused by very minute worms. These live in the ground in some localities and are

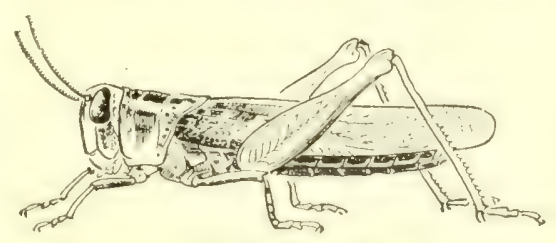

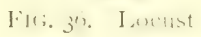
very hard to kill. Where a plant has a disease caused by something that lives in the ground, it is usually best not to try to grow the plant. As a rule, each of the living things which cause disease attacks a certain kind of plants, and is harmless to all others.

\section{INSECT ENEMIES}

Locusts. The insect enemies of plants are numerous and some of them are very destructive. The most destructive of all in the Philippines is the lecust. There 
is hardly any part of the Islands which is not sometimes visited by these insects, in swarms. They eat the leaves of plants, and so kill many crops, but are especial enemies of rice.

Wood Borers and Maize Moth. An insect belonging to the group of wood borers, which make holes in the wood

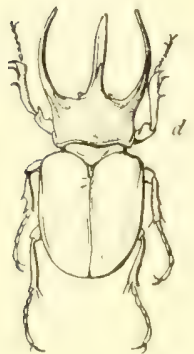

Fic. 37. Hour stages in the complete metamorphosis of the coconut beetle; $a$, egg; $b$, larva; $c$, pupa; $d$, adult

of living trees, has done great injury to the coffee at Lipa; it is called bagombong. The uang, or coconut bectle, makes the great holes often seen in the upper part of coconut trunks. It is also found in cane waste, and other decaying regetation, and in manure. Unless all cane waste is burned or buried, coconuts and cane should not be planted together. About Manila and in some other parts of these islands there is a moth which does great injury to maize.

Larva the Destructive Stage. The maize moth, and the uang and bagombong, are all insects having a complete metamorphosis; that is, each insect, in the course of its life, goes through four stages, namely: 
(a) the egge, (b) the larra, (c) the pupa or cocoon, and (d) the image, or adult stage. The larra, which lookis like a worm rather than like an insect, is the most destructive stage. Except the fiber plants, there is no crop in the Philippines which is not sometimes seriously damaged by insect enemies.

HOW INSECTS ARE FOUGHT

Various Methods Used. There are many ways of fighting insects. The uang, for instance, is fought by many

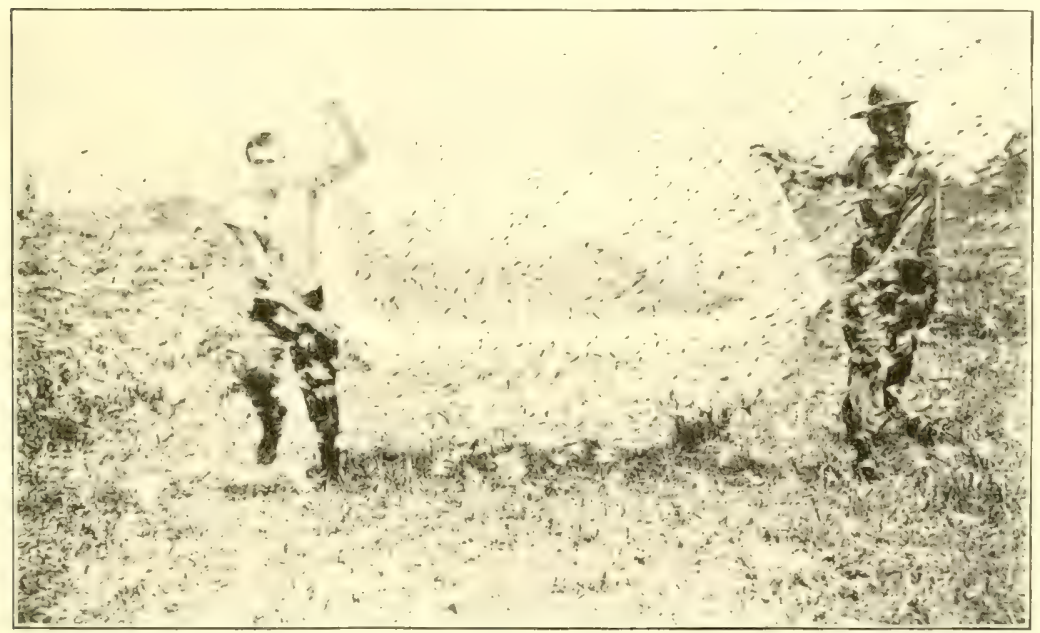

FIG. 38. Catching a swarm of locusts with a net near Manila

different means; such as, pulling him out with a bent pin, and plugging his hole with manure. Locusts are fought by smoke, by sreat nets, by driving them into ditches where they can be killed, and in other ways. The Bureau of Science has tried to bring into the 
Islands a fungus which it is hoped will kill them. Several years ago a man in Negros got some of this fungus from Ifrica, and killed great swarms of locusts within a few days. A common way of killing nightflying insects, such as the maize moth, is to put lamps in the field, with a pan of kerosene under each. The in-

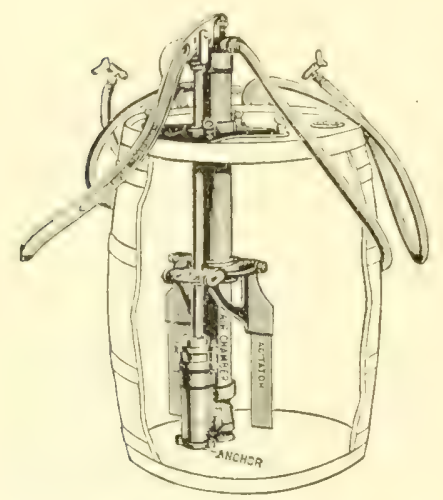

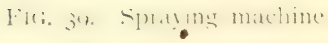
sects are attracted to the light, and fly against it, and then fall into the kerosene. This kills all night-flying insects, some of which are useful; but in fields where the harmful insects are numerous a great many more of them are caught than of the useful insects.

Killing by Poisons. Some substances are disagreeable or poisonous to animals but not harmful to plants. Tobacco juice and arsenic are such substances. If tobacco leaves are boiled in a little water, so as to make a strong juice, and plants or leaves are washed with this juice, insects will keep away from them. If arsenic is put on leaves, insects which eat them will die. It would cost too much to put these poisons on a field crop, like rice; but it often pays to use them on the more valuable garden and orchard crops. They are put on by spraying.

The poison most generally used is Paris green, which contains copper and arsenic. Paris green can be bought 
of any drugegist. To use it, disisolve it in water, putting Io grams of Paris green and ro grams of lime in 6 liters of water. It should be remembered that a poison for insects is usually poisonous for persons. In handling Paris green be careful not to get it on your hands and in this way get it into your month. However, there is one substance, buhace, or Persian insect powder, which gets rid of insects quickly, and which is perfectly safe to use. It is made from a plant called buhac, which could be cultivated in the Philippines.

Kerosene Emulsion. It is impossible to poison the scale insects and other sucking insects. They do not eat leaves, but push a sucking tube inside the leaf, and suck the juice out. But they can be easily killed by spraying over them some kerosene emulsion. To make this, mix 2 liters of kerosene with ro liters of water, and 200 grams of soap; mix these away from the fire while the water is boiling hot, and beat or stir the mixture until the water. and oil do not separate. It is sometimes necessary to re-heat the mixture because it cools before it is perfectly mixed. Blowing air into it with the spraying pump is an easy way to mix it well. For use on a larger scale, make a stronger solution of the oil, and dilute it as it is to be used. To make this strong solution, dissolve I kilo of soap in 5 liters of boiling water, and stir in ro liters of kerosene, boiling and stirring until they will not separate. It is not safe to do this in a house. Unless the mixture is well made, the kerosene will kill the plants. 


\section{FUNGUS ENEMIES}

How scattered. There are fungus parasites (see page 5) on every crop in the Philippines, but they probably do less damage here than in temperate lands. The most destructive here are the coffee rust and maize smut.

These diseases spread from one plant to another by

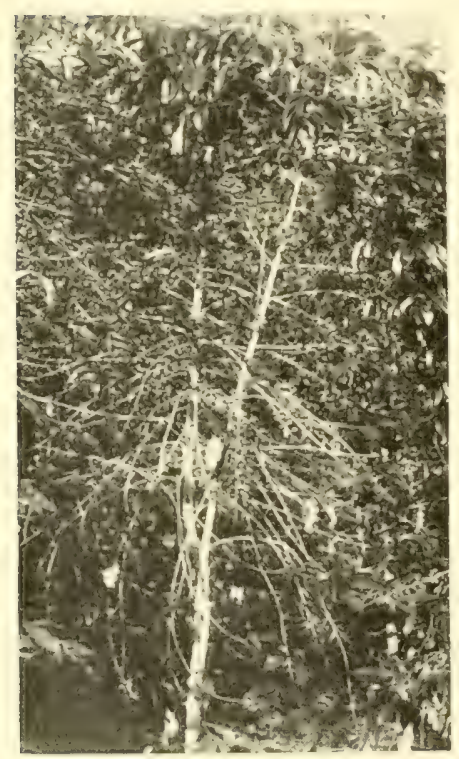

FiG. 40. Coffee plant stripped of leaves by rust means of their spores, which are like little seeds, and from which new plants grow. The smut can get into a maize field on the seed planted, or its spores can be blown in by the wind from a neighboring field. The coffee rust can be brought in on young plants already diseased, or blown in from other fields. The spores are so small that they. cannot be seen without a microscope.

It is as true of the fungus diseases of plants as of the diseases of men that "an ounce of prevention is worth a pound of cure."

How Avoided. Into neighborhoods where a disease does not exist, no live plants should ever be brought from places where it does exist. If necessary to bring in seeds, they should be sterilized. Any spores can be 
killed by putting the seed for three minutes into water at a temperature of $57^{\circ}$. This treatment costs nothing, and may save much. Or the spores can be killed by soaking for one hour in 5 per cent copper sulphate. This substance, commonly called "blue vitriol," can be bought for a small sum in any pharmacy. Either of these treatments is likely to hasten germination.

How Killed. Where a disease already exists on an annual plant, that is, on a plant living less than a whole year, it can be gotten rid of by completely destroying the remains of the plants of any one season. If this is tried, all the leaves and stems should be very carefully collected and burned.

This is sometimes the best way to fight a disease of perennial plants also, but it is very expensive. However, all useless plants ought to be destroyed. For instance, if the people about Lipa desire to raise coffee again, they must first kill and burn the diseased coffee plants that are now scattered along fences and in waste fields. These are of no use whatever, and are as dangerous to healthy neighboring trees as a man with cholera is to his human neighbors. If there are fields of coffee too valuable to be burned up, they should be thoroughly cleaned. All fallen leaves and branches as well as the badly diseased trees should be collected and burned.

Bordeaux Mixture. The spread of fungus discases from living plant to plant is prevented by means of Bordeatur mixture. This mixture is so called because it was first used near the city of Bordeaux, in fighting a fungus 
enemy of the grape. It is composed of copper sulphate and lime.

For use on coffee this should be a 2 per cent solution of copper sulphate, but for most plants I per cent is strong enough. Into this copper solution must be put lime enough to make the mixture neutral. How much lime this takes depends on the freshness of the lime. If the lime is fresh and good, use as much of it as of the copper sulphate. The misture is neutral when red litmus paper placed in it will not turn blue, nor blue litmus paper turn red. It must be used while fresh; that is, soon after it is made. It can be sprayed on plants or trees, or their branches can be dipped into it. Any fungus spores which begin to germinate on leaves treated with this mixture will promptly be killed. Of course, the rain will finally wash it off.

In fighting the coffee rust, the Bordeaux mixture should be put on immediately after the beginning of the rainy season. After this, the trees should be watched; and whenever the yellowish spots made by the disease begin to appear on the under sicle of any leaves, all the trees should be sprayed again. It will be necessary to spray well only two or three times a year, and this will cost much less than the value of the coffee which is saved. Ciarden crops are not often seriously damaged by the attacks of fungi. 


\section{CHAPTER IX}

\section{THE GARDEN}

What the Garden Is. I garden is a place in which small plants, such as flowering plants, vegetables, and small fruits, are cultivated. A field is larger than a garden. Such plants as rice, sugar-cane, etc, which must be grown in large quantities in order to be profitable, are cultivated in fields. Venetables, like tomatoes, cabbage, onions, etc., when grown for profit, are often planted in ficlds. An orehard is a place where only trees are cultivated, while in a garden the plants are mostly herbs.

The Home Garden. 'The garden may furnish food for home use only, or its produce may be sold in the market. Everybody who has land about his house should have a garden to supply his own wants; for he can cultivate it in the spare minutes that would otherwise be wasted. The vegetables so grown at home cost almost nothing. They taste better than those bought, since they may always be used while fresh. Garden crops are very valuable, much more so than most field crops. Therefore, it pays to cultivate gardens much more thoroughly than it is possible to cultivate large fields.

The School Garden. Eivery school in which agriculture is taught must have a garden. The usial garden plants 
should be cultivated in the school garden, and also some field crops, such as sugar-cane, rice, and tobacco.

\section{PREPARATION OF THE SOIL}

Clearing the Ground. Before work is begun on a school garden, the entire garden should be marked off

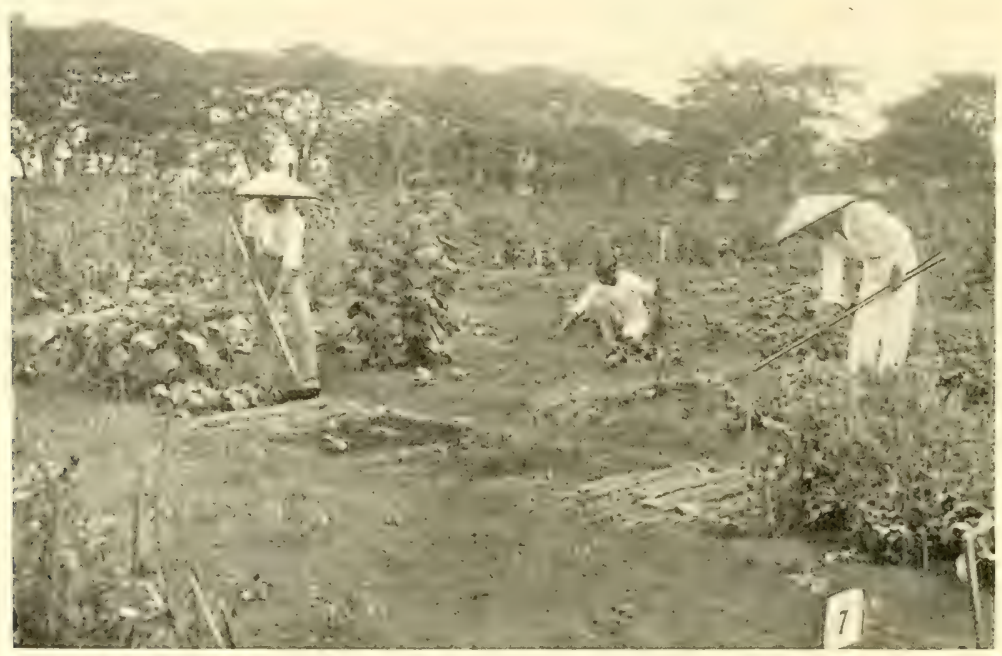

FiG. 4x. Garcien in the grounds of the Plilippine Normal School, Manila

with perfect regularity. Stakes at the corners of each student's plot should be driven firmly into the ground. All sticks and other rubbish on the ground, except herbs - soft enough to rot easily, should then be burned on the plot; and there is no objection to burning the herbs, too, except that the nitrogen in them will then be lost. All stones, even little ones, should be removed entirely from the garden. 
Moisture in Soil. The soil in a garden shemld always be moist and always well aired. Only a soil which is very fine and quite deep will always be both moist and well aired. The method of getting the soil inte just the right condition, and keeping it so, depends on the season. In dry weather the soil must lose as little moisture as possible; therefore, in the dry season the plots must not be made any higher than the paths between them, and the surface must always be kept very fine and level, so that the water will not run off but will sink into the ground.

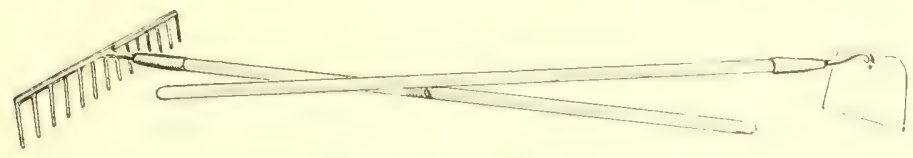

FIG. 42. Hoe and rake

In wet weather, however, the paths may be made somewhat lower than the plots; but if the plots are much higher than the paths, the soil will wash away badly in hard rains. Very wet soil can be broken or hoed up in great clods and left until partly dry. It will dry thus more rapidly than if untouched or made fine. But if these clods are left too long, they will harden and camnot easily be broken.

Plots in which seeds are to be planted should themselies be flat in all seasons. In diy weather flat ground, as we have seen, will lose the least possible moisture.

Planting the Seed. In wet weather, if the scech are planted in furrows, rain is likely to wash the soil over them and bury them so deeply that they will rot, or coren 
if they germinate, be unable ever to reach the surface; while if they are planted in ridges, the rain is likely to wash the soil away and leave them on the surface.

When as much of the garden plot as can be prepared

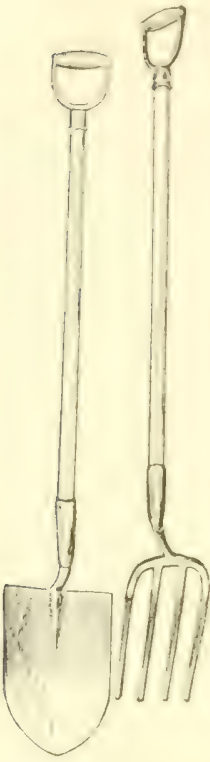

FiG. 43. Spade and fork in one day is ready, the seeds should be planted immediately. If a person spends several days in preparing the soil, and then plants it all at once, he is likely to find the part that was first prepared drier than the part worked later. Thus it will be a poorer place for the germination of the seed (see page I 2).

Fertilizers. If fertilizers are to be used, it is best to work them into the soil before the seeds are planted. Because of the greater value of garden crops, it is common for people who do not put fertilizers on fields to use them on gardens.

Garden Tools. On home gardens it is usually impossible to plow the ground; and this is one reason for not plowing the school garden. The best tool with which to cultivate a small plot of ground deeply is a fork. A spacte is better only when there are rosts in the ground. It is possible to cultivate deeply with a hoe, but not nearly so rapidly as with a fork. After the ground is broken up, a rake is the best hand tool with which to make it very fine. 
Ants and Seeds. There are some kinds of seeds, such as lettuce, tomato, and tobacco, of which ants are very fond, and which are so small that ants can carry them away. If such seeds are planted in soil in which there are ants, very few of them will have a chance to grow. sometimes the ants dentroy ceon large secels which they cannot carry away whole. When the soil is cultivated, the ants in it have their homes broken up. If it is cultivated several times within a few days, the ants will tire of the place and find a home in quieter

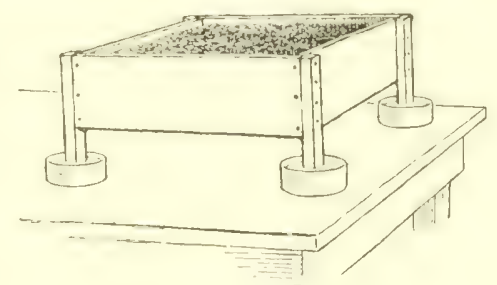

FIr. 4t. A seed box to protect the seed from ants ground; cultivating three times will almost always drive them away. Seeds can then be planted, and, unless the seeds germinate very slowly, they will be entirely safe, for the ants do not disturb the young growing plants.

Another way of protecting the seed is by washing it in petroleum, which will not injure the seed if it is done quickly enough. Some disagrecalste substance, such as pepper, or fer ashes, or buhac, or lime if put into the ground with the seed, will also drive the ants away.

Ant-proof Seed Beds. The surest of all ways to protect secels from ants is by planting them in a box supported by legs which stand in dishes of oil or water. Such a box (an be set in the shade where the soil will not dry rapidly; and if necessary it can be sheltered by a roof, so that 
the soil will not be beaten down or soaked by rain. In such a box the soil can be kept properly moist, and ants cannot reach the seed. Therefore the seed has a better chance to germinate than it is likely to have in the ground.

Advantages of Seed Beds. I seed beel is a place in which seeds are planted close together to germinate, and from which the seedlings are afterward transplanted to their permanent places. The seed bed may be a box or a small plot of ground. It is une gives some adrantages over planting seeds in their permanent places. The young plants can be growing in the seed bed at the same time that the ground is being cuitivated to receive them. In this way comsiderable time can be gained, and in the calce of some crops which thrive well during only a part of the year, this gain of time is important.

Richer and finer soil than that of the garden can be used in the seed bed. This makes the growth of young seedlings very vigorous, and a good start is just as important to a plant as to a boy. The soil in the seed bed should be light, and fine, and deep, so that the roots will be injured as little as possible when transplanted. Sugecetions for transplanting have already been given (see page fo). As a rule, root crops should not be transplanted.

\section{ROOT CROPS}

Camote. Root crops are those which are cultivated for the sake of the roots. Some plants cultivated for the sake of underground stems are also called root crops. 
Some of the root cropse were probably the first cropses exere cultivated by men. In the Philippines and in most ether tropical lands, the sweet potato, or camote, is the most important of them. The sweet potato is the root of the plant called Ipomea Batater, which belongs to the morning-glory genus. It is a native of tropical America, probably about Panama or farther north; but in the Old World it has also been cultivated from very ancient times. It has so long been grown without the use of seed that it very rarely forms

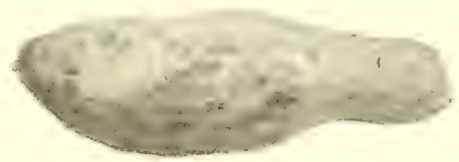

FIG. 45. Sweet potato or camote any; and even the flowers are uncommon in some places.

Planting and Cultivating the Camote. Sweet potatexis are reproduced by cutting off the end of a vigorously growing vine, and putting the cut end in moist ground where it will take root. As often as once a year, it is advisable to use roots for propagation instead of an old vine. For this purpose, the roots are buried close together, about ro $\mathrm{cm}$ deep, in rich ground. In a few weeks there are many vine branches growing from each root, and the tips of these are cut off and used in the way just described. In most parts of the Philippines the sweet potateres are of pont quality being mall and stringy. Poor cultivation is a cause of both of these defects. This plant wants soil which is light, but rich.

What shape have the leaves of the sweet potato?

What shape is the sweet potato?

How large do sweet potatoes grow? 


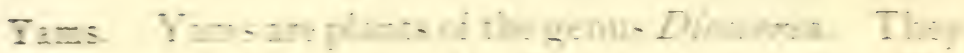

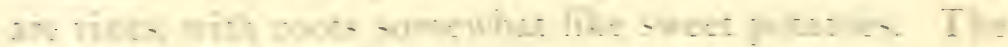

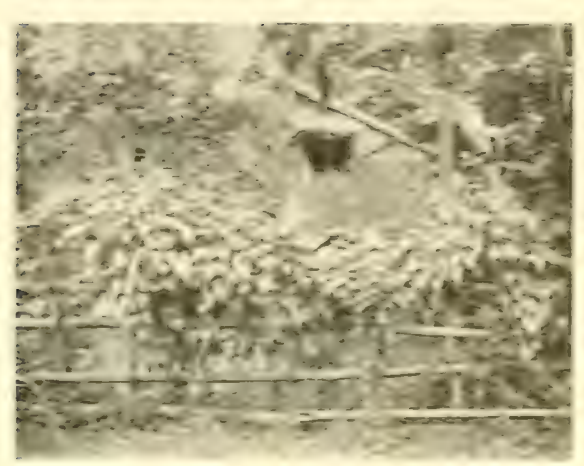

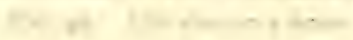

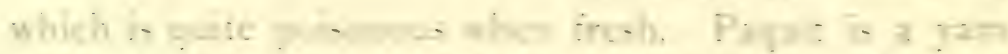

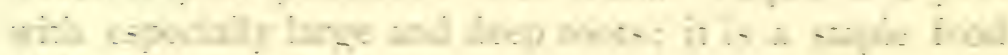

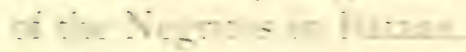

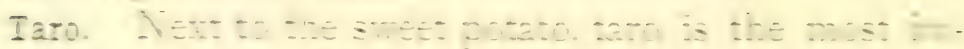

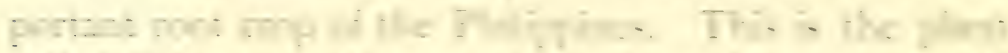

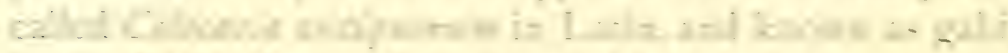

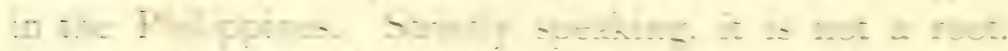

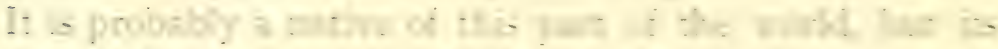

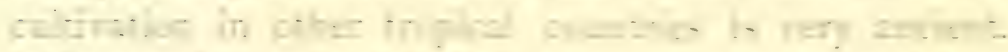

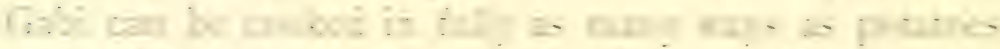

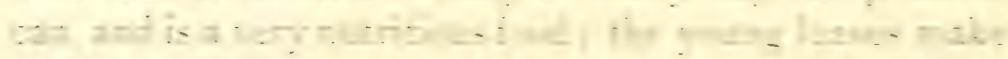

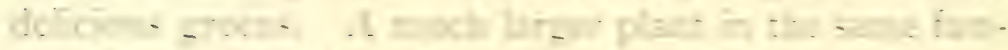

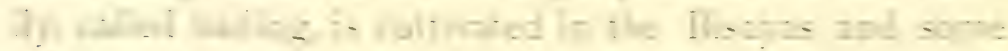

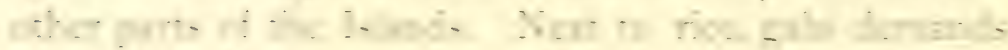

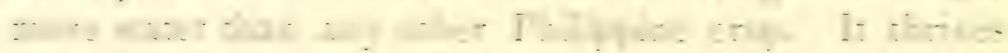

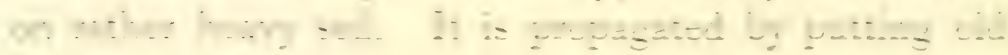


"roots" in the ground; each of these soon forms sereral small plants.

Beets. Several root crops of northern countries have been introduced into the Philippines within the last few years. Among these are the beet, turnip, red radish, carrot, and parsnip. The beet is the most important of these. It is a native of Europe. The real seed is very small, but is alrays inclosed in a corliy calyx.

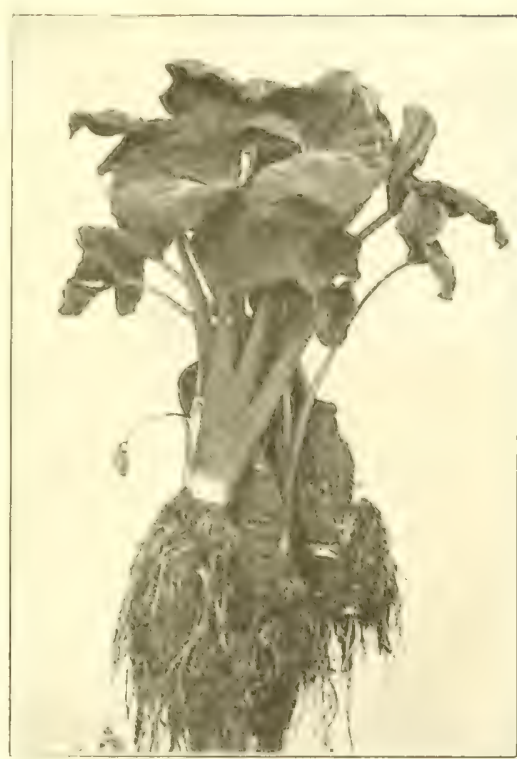

Fic, 47. Taro, or gabi

There are several different varietics of beets, which have different uses. In temperate countries, the most important is the sugar beet; but as it is a

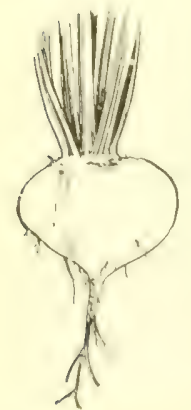

Fll: 48. Beet more expensive souree of sugar than is the sugar-cane, it would be foolish to grow this plant in the Philippines. Another very large beet is cultivated as a food for cattle. The sarden beet has a thick, red root, which is cooked in various ways, and is a very nourishing food. The red leaves and petioles are also eaten as greens. Beets grow well in soil that is heavy, but not too wet. 
Planting and Culture of Beets. All of these plants should be planted in rows $30 \mathrm{~cm}$ apart, the seeds $\mathrm{I} \mathrm{cm}$ deep, corered by very fine soil. The young plants should be

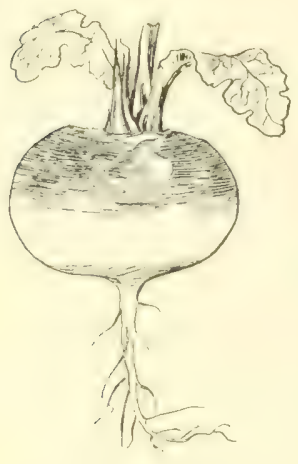

Fig. 49. Turnip I $5 \mathrm{~cm}$ apart in the rows. The beet, turnip, and parsnip will soon become crowded; and then every second plant should be removed and eaten.

The turnip and radish grow best on lighter soil. For parsnips the ground must be especially deep; therefore, they are a dry-season crop. Turnips, radishes, mustard, and cabbages are nearly related plants, and have the same diseases and enemies.

In the Normal School garden in Manila, the arerage time between planting and harvesting root creps was: radishes, 5 I days; turnips, 60 days; beets, 7 I days; carrots, 75 days. Cincomas is a Philippine root crop which belongs in the legume family of plants. In the Normal School garden it was harvested in 68 days, but was not mature. If the roots are left a long time in the ground, they cease to be sweet, as most of the sugar in them is changed to starch.

0nions. The part that we eat grows in the ground but is not a root. In the Philippines

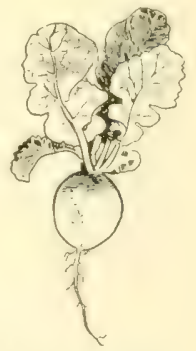
FIG. 50. Radish the onion thrives only in the dry season. The onion plant reproduces poorly by seed. Its relative, the garlic or bauang, is a more important crop here. 


\section{LEAF CROPS}

There are many plants whose leaves or young shoots are eaten fresh, or cooked and eaten as greens. The garden plants raised in the Philippines for their leaves are mustard, cabbage, and lettuce. All of these are agreeable but not very valuable foods. All have small seed, which should be planted not more than I $\mathrm{cm}$

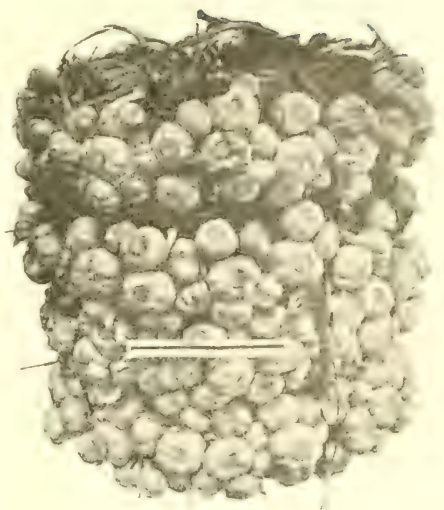

Fli. 5I. Ginlt: deep, in very fine soil.

Mustard. Mustarel is best planted where the plants are to grow, and not in a seed bed. The rows should be $30 \mathrm{~cm}$ apart, and the plants Io or $5 \mathrm{~cm}$ apart in each

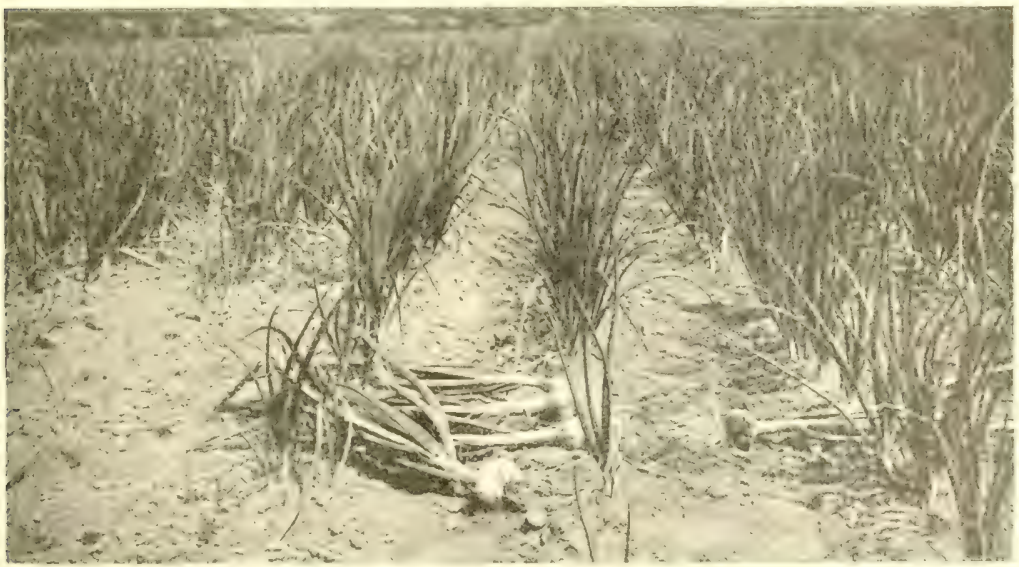

Fig. 52. A field of onions 
row. At this distance, the plants will be crowded before they are full-grown; and crowded plants have more tender leaves than do plants with more room. In the Normal School garden, mustard matures in $4+$ days.

Pe Chai. Pe chai is a Chinese plant which is planted and used like mustard. It is really a cabbage, but does not form heads in the Philippines. If the outer leares are always removed before they become old, new ones

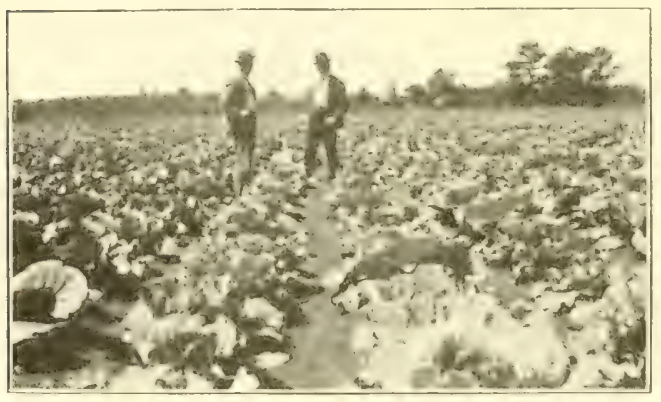

FiG, 53. A cabbage field

will keep on growing, so that the same plants will produce fresh leaves for several months.

Cabbage. Cabbages are better planted in seed beds, because they need to be far apart, and it is a waste of time to have to cultivate the ground between them while they are very small. In the mountains very fine and large cabbages are grown; but in the plains of the Philippines, where they will grow only in the dry season, they are not large and not as hard as they should be. 'They should not be planted later than October, because they require a long season, and because the insects which attack them are least numerous early in the dry season. Cabbages should be $50 \mathrm{~cm}$ apart in each direction. 
Lettuce. Lettuce also is best planted in seed beds, because otherwise ants are likely to steal the seed. The young lettuce plants must be transplanted very carefully, or they will not grow for some time afterwards. The rows should be $30 \mathrm{~cm}$ apart, and the plants $20 \mathrm{~cm}$ apart in each row. They should be harvested before the flowering stem begins to grow above the leaves. Lettuce should

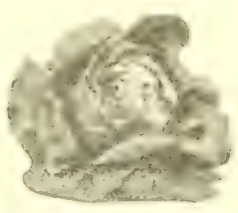

FIf: 5. A head of lettuce be shaded for several days before it is cut. This checks the transpiration, and makes the leaves tender.

\section{THE SQUASH FAMLY}

The cultivated plants of the squash family are squashes and pumpkins, gourds, melons, and cucumbers. These are all large-leaved vines, valuable for

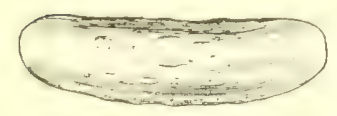

FIG. 55. Cucumber their fruit. All of them require wellaired soil. They grow best, or only, in the diry season. The squashes are the most important of them.

Squash Hills. Siquahes are planted in hills. To make a good hill, a round hole is dug, $20 \mathrm{~cm}$ deep, and $80 \mathrm{~cm}$ in diameter. The earth taken out is then well mixed with one quarter as much rotten manure as earth. The mixture is then put back into the hole. This makes a hill, higher than the swound around it, and therefore well aired. The ground should not be fertilized later in the season, because if this is done, the plants are likely to produce long vines with little fruit. As many as three 
plants can grow in one hill. The distance between hills depends on the variety of squash. Some varieties have long vines; some, short ones.

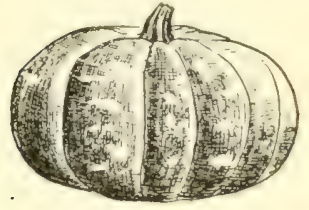

FIG. 56. Squash

Care of the Vines. In temperate countries, squash vines lie on the ground; but in the Philippines, because the climate is more moist, they are usually given supports on which to climb. They may as well be left on the ground, however, unless it is wet enough to make the fruit decay. The vines will take root at the nodes. After the vines become strong and healthy; these roots must be cut on the young parts, or the plants will make long vines, instead of much fruit. After a young squash appears on a vine, it is best to cut the tip of the branch; this makes the plant put its strength into the fruit.

Varieties. There are many varieties of squashes, differing in size, shape, taste, and in the time it

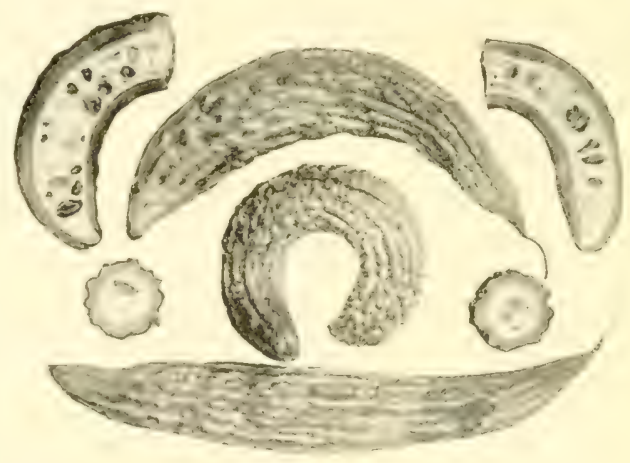

FIG. 57. Ampalaya

takes them to mature. The American squashes mature much more quickly than do those common in the Philippines, but are more likely to be injured by insects and diseases. Ampalaya and upo are gourds rather than 
squasthes, and the rines need a support upon which they can climb.

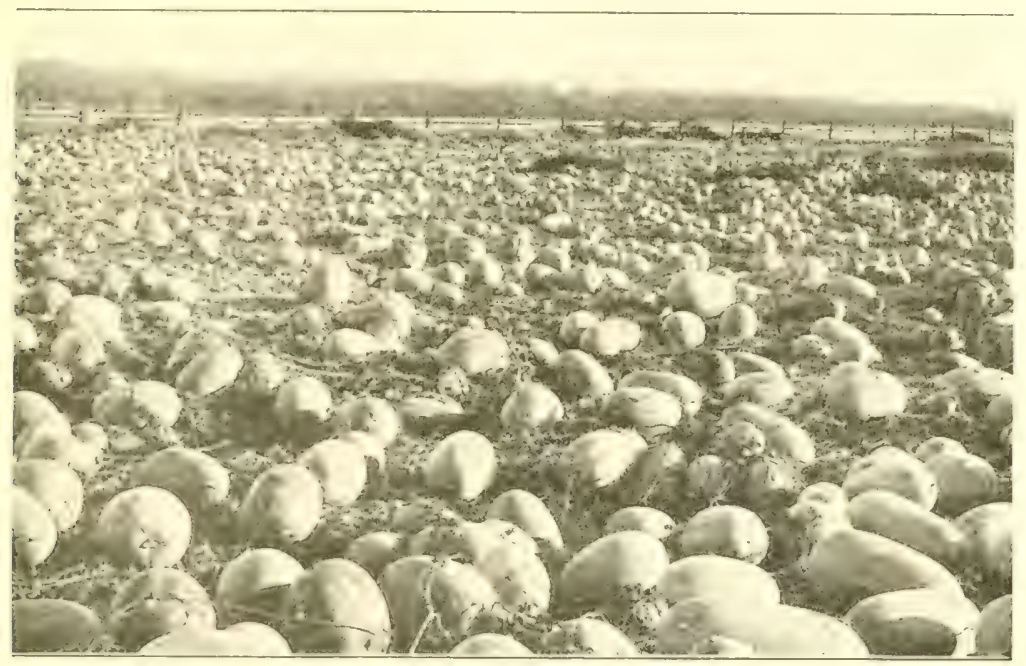

FIG. 58. Field of watermelons in California

Melons and cucumbers require a rich but very light soil. In most parts of the Philippines these plants have not gromm well, and have usually been killed by diseases. Inowerer, in some places, as at Bautista, in Pangasinan, and at Zamboanga, excellent melons are grown.

\section{LEGUMES}

Special Value of Legumes. The legume family includes all the garden plants with fruit similar to that of the bean. This is a very large family, and includes many valuable plants not cultivated in gardens; among these are the tamarind, or sompalok, camanchili, catturay, narra, 
acle, ipil, and tindalo. We have already learned (see page 29) that the plants of this family have nodules, or tubercles, on their roots, and that in these nodules the nitrogen of the air is fixed. The legumes are especially useful crops, because instead of making the soil poorer, they leave it richer in this valuable plant food. All of these plants grow well in soil rich in lime.

Kinds of Garden Legumes. The cultivated legumes are the cincomas, pea, the various beans, the indigo, and the peanut. Peas have been harvested from the Philippine Normal School garden 29 days after planting; but it was a small crop and the plants were already dying with the first fruit. Neither the American pea nor the Spanish garbanzo has been found suited to general cultivation here.

Beans. There are sereral valuable garden plants which can be grouped as beans. All of these are valuable foods, because they are rich in protedis, the substance for which lean meat is eaten. For this reason they are especially valu.able to people who do not often cat meat. I persom who eats enough beans need never eat meat or egges for their proteid.

Different Kinds of Beans. Some of these beans are climbing vines; others are bushy plants. The patani is the most important climbing bean. Among the bushy ones are the American bush beans, which are natives of South America, and the mungo or balatong, which is a native of India or Malaya. The mungo is a very productive and easily cultivated plant, which will grow on 
almost any soil, and endures much water. A great many are eaten in the Philippines, and some are exported to China. Cagyos, whose Latin name is Cajanus Indicus, is an erect plant, sometimes 2 meters high; it produces its fruit about February, when other legumes are least abundant. Sitao and batao are Manila names of climbing legumes; batao has an especially fine flavor.

The Peanut. The peanut, Arachis hypogaed, called mani in the Philippines, is valuable both as a garden and as a field crop. It is a native of Brazil, but is cultivated in all tropical lands. The stem and leaves are good fodder for beasts, and the seeds are valuable as food and as a source of oil. The oil is used to make soap, to adulteratecacao, and in otherways.

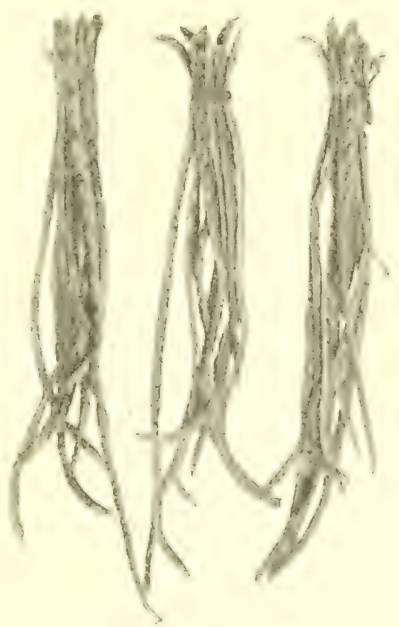

Fl6. 59. Sitzo

Conditions of Growth. The peanut grows in the tropics, and in temperate countries where there are four months of hot summer without cold nights. It can endure considerable dryness, and will grow in any soil which is not very wet or heavy. If it is grown for the oil, light colored soils are best, because the nuts and oil are there lighter colored; and light oil sells at a better price than dark. On a soil poor in lime but little fruit is produced.

In the tropics the seeds sometimes contain 50 per 
cent of oil. In the United States, the oil is hardly more than 25 per cent of the seeds: but the seeds without too much oil are best to eat. The seeds are short-lived, especially if they are not very dry.

Culture of Peanuts. The soil for peanuts should not be cultivated more than Io or at most I $5 \mathrm{~cm}$ deep. On

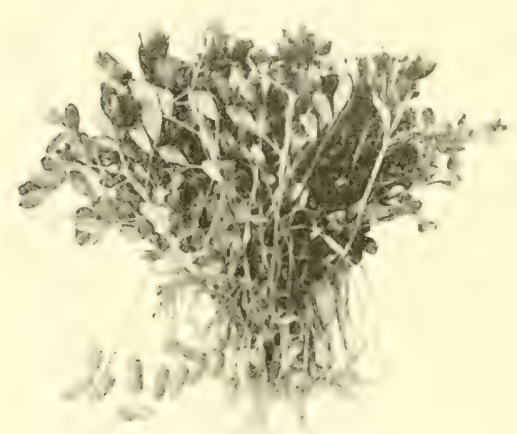

FIG. 60. Peanut plant with fruit rich ground, the peanuts should be planted $2.5 \mathrm{~cm}$ reep, in rows $120 \mathrm{~cm}$ apart. and $80 \mathrm{~cm}$ apart in each row, with 2 nuts in each place. On poorer ground they may be planted closer together. The plants will come up in from io to 14 days. While they are still young, they should be cultivated shallowly, about three times. The flowers are borne on short stalks in the axils of the leaves. After blossoming, the flowers wither; then the flower-stalk elongates, bends downward, and pushes the young seeds or fruit into the earth. The seeds go down into the ground as far as they can. If the ground is soft, they will grow downward for a long time instead of ripening; and when they do ripen, they are hard to harvest and many are lost.

Harvesting Peanuts. When the crop is thoroughly ripe, the ground is softened enough so that the plants can be pulled out, with their fruit. If they are then left 
in the sun two weeks, to dry, the seed can easily be removed, and the stems and leaves will be better an fodder than when green and fresh.

Indigo. Twenty years ago, this was a very important crop in the Philippines, especially in Ilocos Sur. But some of the indigo growers and merchants there put other substances into the indigo, so as to make more money; and after a little while nobody would pay a good price for any of their indigo. Even good indigo sells for a much lower price now than it formerly did. Indigo is planted $\mathrm{I} \mathrm{cm}$ deep, in rows $40 \mathrm{~cm}$ apart, several seeds in a bunch, and the bunches I 5 to $20 \mathrm{~cm}$ apart. Twenty-four liters of seed will plant I hektar. It may be planted whenever it is likely to receive light rains, or in the driest season if it can

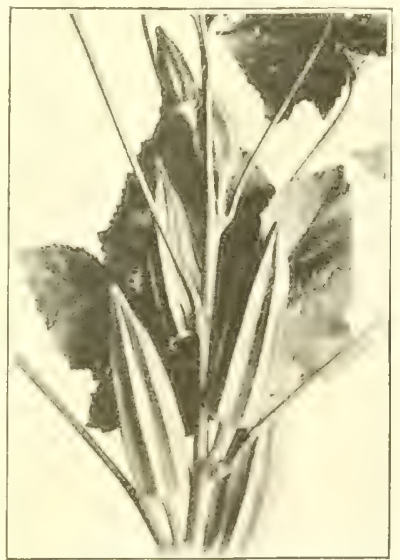

FIG. 6i. Okra be irrigated. In Ilocos it is planted from November to February. It lives nine or ten months and gives two or three crops. The plants are cut when in flower. Two hundred kilos of plants will make I kilo of first quality indigo, or 2 kilos of "corriente."

\section{GARDEN FRUITS}

Okra. The common soft garden fruits are okra, tomato, eggplant, and pepper. Okra is a native of 
Malaya, and thrives in the Philippines under all conditions and in all seasons better than any other garden crop. The plants should stand $50 \mathrm{~cm}$ apart in each direction; but on very rich soil or in moist weather they may be farther apart. The fruit is useful only when it is young and tender. Then it may be used in making soup, stewed with other vegetables, or cooked alone.

Tomatoes. Tomatoes should be planted in boxes or seed beds, both because the ants like the seed, and be-

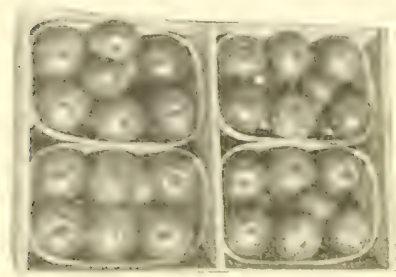

Fir. 62. Tomatoes boxed for market

cause the plants, like cabbage, must finally be set regularly, far apart. The seed can be planted in boxes before the end of the wet season, and transplanted as soon as the soil is dry enough.

The plants should be transplanted carefully before they are ro $\mathrm{cm}$ high; they should be $80 \mathrm{~cm}$ apart each way. Tomatoes demand rich soil, which may be heavy or light; but neither the soil nor the air should be very moist.

When the plants begin to bear fruit, they should be kept up in the air by a wooden frame, or else some dry grass or leaves should be put on the ground to keep the fruit clean. On good and fine soil, tomatoes do not need to be irrigated after they begin to bear fruit. Too much water makes them precluce branches instead of fruit.

Eggplant. The esglolant, or talong, is probably Last Indian in origin. It is a fruit with fine flavor, but not of 
much food value. The seeds can be planted in seed beds, or in their permanent places; the seed bed is rather better. The common talong in the Philippines has'a long, slen-

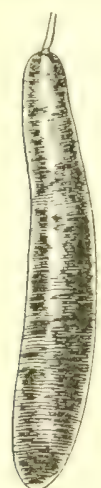
der, black fruit; while the sced from America usually produces a much larger but shorter fruit. The Philip- Frc. 63. Americun pine plants are smaller, and

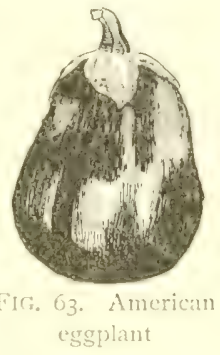
can be planted $45 \mathrm{~cm}$ apart, while $60 \mathrm{~cm}$ is close enough for the American variety. Red Pepper. The red pepper, of which the green pepper is a variety, is a naFIc. 64. Philippine tive of America. It is like eggplant the eggplant in being eaten chiefly because it has a pleasant taste. It should be planted like the Philippine eggplant.

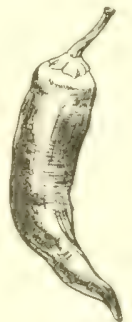

F'1G. 65. Red peptren

Why are parsnips not likely to live in the rainy season? Answer fully. Why is it not necessary to plant mustard in a seed bed? 


\section{CHAPTER X}

\section{STARCH PLANTS}

STARCI is formed in the leaves of most plants, in the sunlight; but this starch is soon used by the plant for its own growth, and leaven never contain conough starch so that it would pay to try to extract it. Many plants also store up starch in their roots, trunks, or in other parts to be uned later in making fruit, or in propargating themselves in some other way.

The thick trunk of the buri palm is a place in which starch is stored up for many years, and then used all in one season in making fruit. Every Filipino knows that he can get good starch from this trunk. Sago is a kind of starch obtained from certain palms and other similar trees. Starch is also easily obtained from the fruit of rice and maize. Three root crops which are important sources of starch are maniok or cassava, potato, and arrowroot.

\section{MANIOK}

History of the Plant. Maniole is the plant called camoting caluy in the I'hilippines, and known in botany as Manihot utilissima. It is a native of tropical America, where there are many other species of Manihot. ()ne of the is Manihot Glasioniz, the Ceara rubber, which is now being planted in the Philippines. 


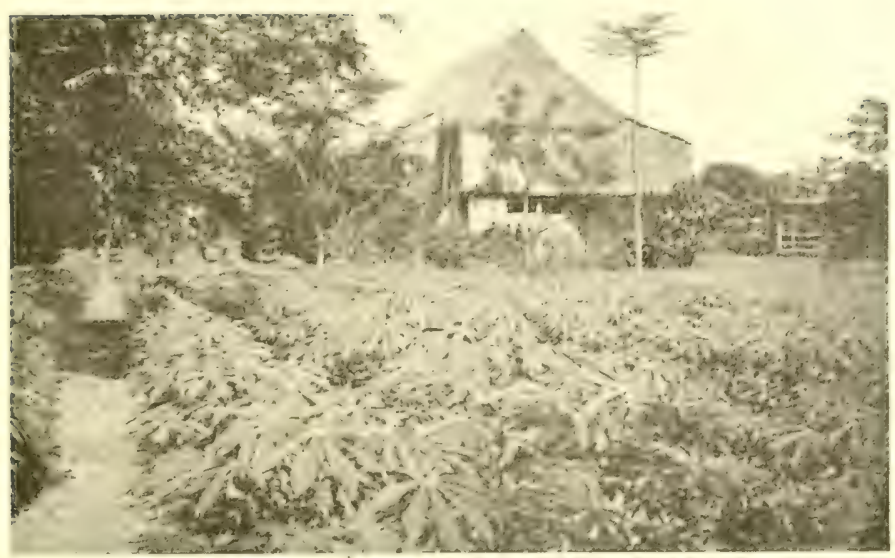

EIG. 66. Maniok, or camoting cahoy, or cassava

Maniok was the most important food plant of all tropical America when the Europeann discovered that country. It grows well only in the tropics. A temperature as low as $10^{\circ}$ is injurious to it. The plant is now cultivated in all tropical countries, but its starch is experted chietly from Brovil and the straits Settlements (Singapore). It is cultivated in Filorida, but yickds small and poor crops there.

Sweet and Bitter Maniok. The routs of all the specien contain Prussic acicl, a very poisonous substance. If they contain much of this, or if much of it is in the starchy pith, the plant is called bitter maniok; some varietie rontain but little, and are called - weet maniok. The Prussic acid can be removed by careful washing of the roots, be ronting or cooking. or by thomengh drying in the sun. Sweet maniok endures a cooler country and 
poorer soil than bitter maniok, but in such places it produces less starch.

Conditions of Growth. Maniok needs frequent showers during the first two monthe of its growth, but after this time endures dry weather well. However, if the air is very dry, the crop is coarse. Its soil should be deep, rich, fine, and loose. Good forest soil is of this kind, and in the Straits Settlements maniok is cultivated by the caingin system (see page 30).

Maniok exhausts the soil so rapidly that after it has been grown only three years on the same soil the crops become considerably smaller. The food which it takes from the soil in great quantities is nitrogen. Therefore, in order to obtain good crops year after year it is necessary to use green manures. A rotation of crops, in which peanuts, or mungos, are planted instead of maniok every third year, will keep the soil fertile for a long time. The fertility will be still better retained if lime is put on the soil before the legumes are planted.

Planting and Cultivation. Maniok is practically seeclless, and is propagated by putting pieces of the stems in the ground. Each of these pieces must contain at least one node, from which the young plant will grow. On good ground they should be planted in rows I meter apart, being placed $80 \mathrm{~cm}$ apart in each row. The ground should be cultivated well during the first two months. After that time the maniok will keep the weeds down; but some later cultivation will improve the crop. 
Some short-lived crop, such as mungo or maize, may be planted between the plants of maniok; this will mature and be removed before the maniok is full-grown. Maniok will produce some roots on poor ground, and without any cultivation; but it is of course not a prolific crop if treated in this way. The green branches of the plant should never be cut off; but if flowers begin to grow, they should be removed.

How the Starch is Secured. 'The crop) in realy to hallvest when the roots are fullest of starch. If it is well cultivated, this should be in 9 to 14 months. After that time the starch begins to decrease. The roots can be cooked and caten, if desired, like yams or sweet potatoes.

If they are to be used as a source of starch, the roots must be very thoroughly washed, and then peeled. When clean and white, they are scraped or ground into a fine pulp. Clean water should then be used to wash the starch out of this pulp, and into tanks, leaving the fibrous part behind. The starch is so fine that it will rum through fine cloth; so if the ground roots are washed across a tank or trough with a cloth top, the water and starch fall through the cloth, but the fibers wash away. After the starch settles in the tanks, the water is run off. The starch is washed until perfectly white, and then dried. No dust must be allowed to fall on it, for only pure white starch sells at a good price.

A very cheap machine for scraping the roots into pulp can be made by filling a sheet of sheet-iron with nail holes, the nail alwats being driven throligh in the same dirertion. 
The sheet is then fastened around a wooden cylinder, the rough side outward. This cylinder is turned rapidly inside a larger cylinder or rounded box, with the roots between the two.

Yield. The average vield of each plant should be fully 5 kilos of roots, or more than 60 tons to the hektar. Thirty per cent of the weight of the roots should be starch, and three quarters of this can be easily washed out. Tapioca is the finest starch made from the maniok plant.

\section{POTATO}

History of the Potato. The potato, whose name is Solanum tuberosum, is also a native of tropical America, but it grew there only in the mountaineus regions. It was in cultivation by the Indians as far north as Virginia. The potato ranks with maize and tobacco as one of the plants which thrive in many different climates. Although native in the tropics, it is an important crop in Canada.

Conditions of Growth. The potato was introduced long ago into the Philippines, but it has not been well cultivated, and therefore has never become an important crop. Except on very light or well-drained soil, it can be grown only in the dry season. When there is not too much water, it thrives on heavy soil, which should not be poor in lime.

Planting. The potato tuber is not a ront, but an underground stem. Its nodes are marked by the "eyes." Branches or new plants can grow from these, just as from 
the nodes of a maniok stem. The potato is propagated, therefore, by means of the tubers. It is best to select large, smooth ones. 'The tubers should be cut into pieces as large as a chico, and each piece must contain at least one eye. The ground must be soft to a depth of $20 \mathrm{~cm}$ or more; large tubers cannot possibly be formed in hard ground. The potatoes or pieces are planted in rows $60 \mathrm{~cm}$ apart, and placed 30 $\mathrm{cm}$ apart in each row. Unless the ground is very wet, they should be planted I 2 $\mathrm{cm}$ deep, and covered by

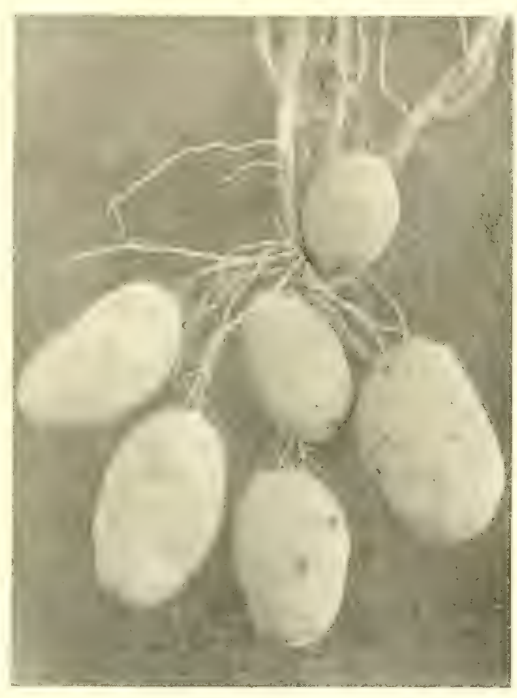

FIG. 67. P'otatoes soft soil.

Cultivation and Harvesting. As the plants grow, the soil must be cultivated frequently, to keep it soft and to keep down the weeds. After the tops become $20 \mathrm{~cm}$ or more high, some of the soil between the rows should be drawn around the plants. This is called "hilling" the plants. The leaves turn brown when the crop is mature.

In the garden of the Normal School, good potatoes have been harvested 55 days after planting, the crop yielding 6 tons to the hektar. It would not be profitable to raise potatoes in the Philippines as a source of 
stareh: but they are an excellent food, for which there is a good local market.

\section{ARROWROOT}

Climate. Irrowront is also a native of tropical America, but it is now cultivated in all tropical and subtropical

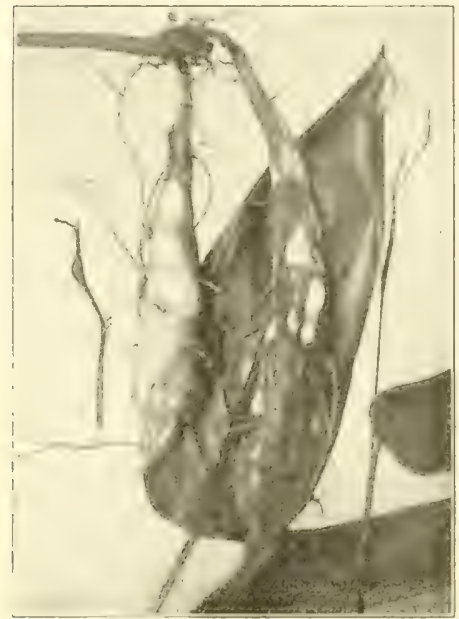

FiG. 68. Arrowroot lands. Although a plant of warm countries, it can endure frost at about the time of harvest. Except when young and growing rapidly, it also endures drought, or dry weather, well.

Culture. Arrowroot requires a fairly light soil, cultivated very deep and very fine. The starch of arrowroot is stored in rhizomes. A rhizome is an underground stem which, instead of being a tuber, like the potato, is long and grows horizontally. About three months before planting time, the largest rhizomes from the previous crop are planted in a seed bed. These produce numerous branches, which are ready to plant when as thick as a finger. These branches are planted like potatoes, but not hilled so high in cultivation.

Harvesting. It takes almost a year for arrowroot to mature. The rhizomes are then dug up, being found 
mostly at a depth of 30 to $45 \mathrm{~cm}$. The arrowroot yields the highest priced starch, but it produces much less of it than do potato and maniok.

If the useless part of the plant is left in the ground after the harvest, this crop will exhaust the soil very slowly.

In what parts of plants is starch to be found?

Name several starch plants that are to be found in the Philippines. Which are the most important?

What kind of soil does maniok require?

How is maniok propagated?

For what are potatoes grown in the Philippines?

What is a rhizome? 


\section{CHAPTER XI}

\section{MAIZE}

History of Maize. Maize is the name of a plant whose Latin name is Zea Mais, of the grass family. The fruit of this plant is also called maize. Although little is known

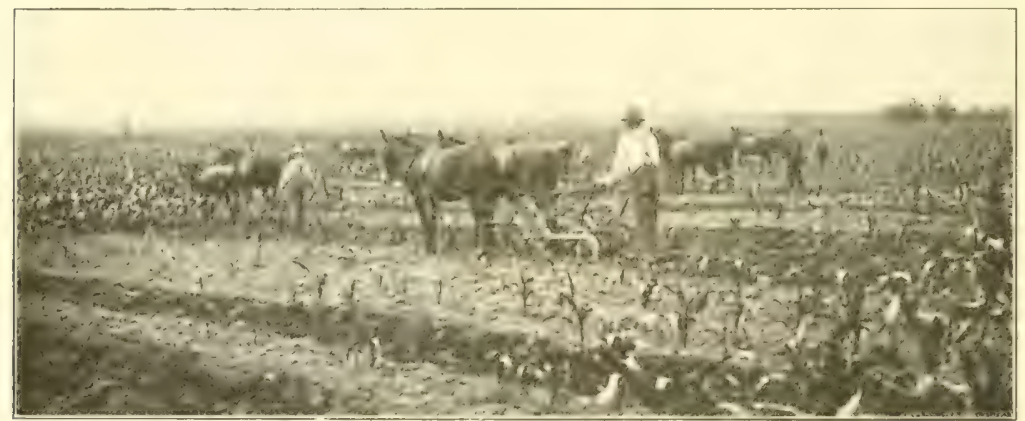

Fic, 69. Ficld of maize under cultivation

about where maize forst grew, it is cloubtless a native of the mountainous part of trepical America. It has been very long in cultivation, and was the staple crop of the Indians as far north as New England when that country was first visited by Europeans. In America "corn," which originally meant any grain, is a commoner name than maize for this plant. Sereral hunded varieties of maize have been developed in cultivation. These fall mostly into six groups: husk maize, tooth maize, starch 
maize, flint maiz, stgar maize, and popeorn. The most important group is starch maize.

General Description. Maize is a great grass, whose height varies in different varieties from $60 \mathrm{~cm}$ to 6 meters. Except in the Chinese "tree corn," which is a variety of husk maize, the stem is unbranched, or, rarely, is branched near the base. The leaves are alternate, in two rows. They are usually rough on the upper surface, but smooth below. In size they are 30 to $\mathrm{I} 20 \mathrm{~cm}$ long, and 5 to $12 \mathrm{~cm}$ broad.

Two Kinds of Inflorescences. Examine carefully the picture of the stalk of maize, and you will notice that it has two different clusters of flowers. Clusters of flowers such as these are called inflorescences.

()ne cluster or inflorescence grours from the top of the stalk and forms the tassel. Since all these flowers

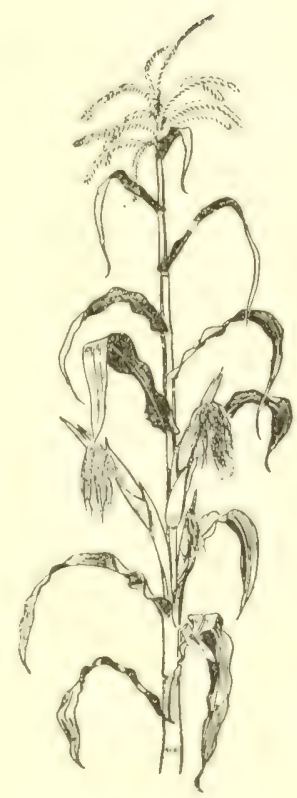

FIG. 7o, Stalk of maize shemine the stummate infleresenene at the top and three pistillate inflorescences in the leaf axils have only stamens and no pistils, this cluster is called the staminate inflorescence.

The flowers having the pistils grow in clusters alomg the side of the stalk in the axils of the leaves. These clusters are called the pistillate inflerescences. I stalk may have from one to three pistillate inflorescences.

Each pistillate inflorescence is a stout stem, or axis, 
bearing usually eight to ten rows of Howers. Strictly speaking, the flowers are in pairs; but the lower of each two flowers is very small and undeveloped, while the other is larger and apparently alone. The flower has a naked

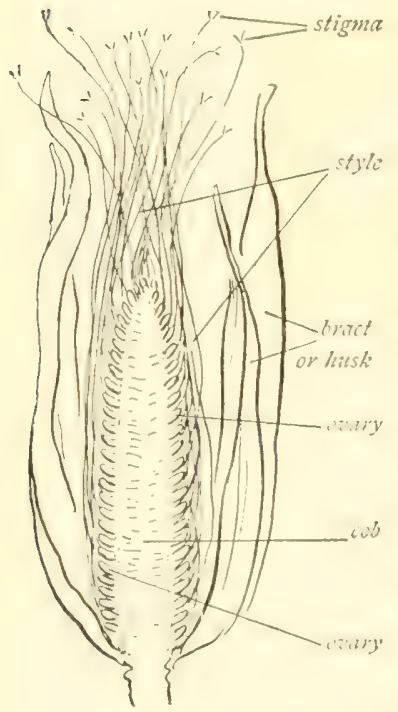

F1G. 7T. Diagram of the pistillate inflorescence ovary, and an exceedingly long style. The styles form the corn silk. The whole inflorescence is inclosed by numerous bracts, which make up the husk. The silk comes out through the end of the husk. As the fruit ripens, the axis of the inflorescence becomes the cob. Each grain of maize is really a fruit, the whole "ear" being composed of the cob and very many single fruits, or kerinclis.

Pollination. Each flower of the staminate inflorescence has three stamens, whose anthers are hung by the middle, and sway in the wind. The pollen is carried to the stigmas below chietly by the wind, but insects sometimes carry some of it. A grain of pollen must fall on every stigma, for no ovary can become a grain of corm unlesis its stigma is pollinated (see Glossary).

The wind scatters the pollen in every direction, and almost all of it falls on the ground. When maize is planted in large fields, the air fills with pollen, and almost 
every stigma is sure to receive some. But if a small number of plants are alone, or if they are scattered sparsely oser the land, there will be so little pollen in the air that many stigmas will receive none of it; then the grains will be scattered over the cob instead of entirely covering it.

Sterile Plants. In every field some plants bear no cars. Plants that bear no fruit are called sterile. These plants are valueless. By scattering their pollen, these plants without ears have descendants, which inherit their sterility. In
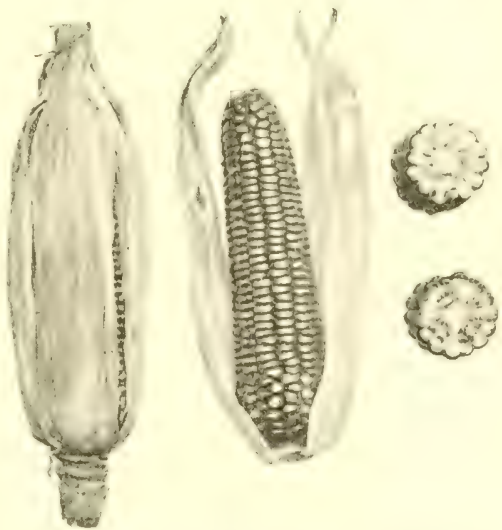

FIc.72. Ear of maize inclosed in the husk, an ear with husk partly removed, and two cross sections

a field from which seed is to be taken, the top of every sterile plant should be remored before its pollen is scattered. In this way the sterile plants have been reduced in a single year from 8 . I I per cent to 3.44 per cent.

How tall have you seen maize grow? How many ears have you ever seen on a stalk? Which inflorescence appears first on the stalk? What is the color of maize "silk"? Why do some ears have only" few seeds? How many rows of seeds usually grow on a cob?

Draw a stalk of maize showing inflorescences.

Draw the flowers of maize, and name the parts.

Uses of Maize. Maize is useful in several ways. IIhen milk-ripe - that is, just before the grain hardens - it is 
cooked and eaten. At this time it is one of the most nourishing and digestible of all regetables. When fully ripe, the grain is ground into meal and used as food. This also is very nourishing.

Corn satisfies our need for nomrishment more perfectly than rice does, because it contains more fat and more proteid, but not so much starch. The grain is used for the manufacture of starch. Maize is largely used in making alcoholic liquor and for other purposes. In America the fruit of maize is the most important food for beasts. The stalks and leaves are also fed to cattle, and are called fodder.

Production. According to a rough estimate by the I) partment of Igriculture in IVashington, the production of maize in the world is:

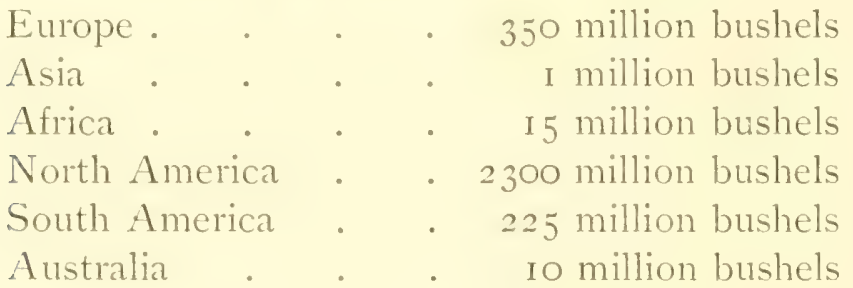

A bushel of maize is 25.4 kilos. In most years the United States produces more than three fourths of all the maize in the world. This crop is worth 2,500,000,000 pesos yearly to the American farmers. Maize is grown in all parts of the Philippines. It is most important in Cebu and the neighboring islands and in the Cagayan valley of Luzon. 


\section{CONDITIONS OF GROWTH}

Range of Climate. Maize ranks with the potato, and before tobacco, as a plant which grows under the widest range of climates. In Canada it is profitably cultivated as far north as $5 \mathrm{I}^{\circ}$, and in the tropics it grows in Peru at an altitude of 3500 meters. Different varieties, of course, fit clifferent climates. Some varieties mature in so short a time as 75 days; many require $\mathrm{I}$ oo days, and some I 20 days.

Corn matures most favorably during hot weather. There is no part of the Philippines whose climate is not suited to the growth of some varieties of maize. Maize requires much light, and will not thrive at all in the shade. Even a few days of cloudy weather check its growth.

Rainfall or Irrigation Essential. Showers are especially favorable to the growth of maize while it is still young. To produce a good crop, the roots must take up an amount of water equal to a layer $\mathrm{I} 5$ to $25 \mathrm{~cm}$ deep over the whole field. Of course they cannot do this unless the ramfall is much greater than this, or moless the field is irrigated. A rainfall of 30 to $60 \mathrm{~cm}$ is desirable cluring the growth of maize. Irrigation is very helpful, and in a moderately dry reason has been found in Lomisiana to increase the crop Ioo per cent.

The roots of maize ge deeper into the ground than do those of any other common annual plant. Therefore they can draw water from deep in the ground, cren at 
far down as 2 meters. But many of the roots grow near the surface, and the deeper roots alone cannot keep the plants well supplied. Because the roots go deep into the soil, and so loosen and open the deeper layers of earth, maize increases the water-holding power of the soil. It has been found in Dakota that in a wet season wheat produces about as well on ground which produced wheat the year before as on ground which produced maize; but in a dry season land which had produced wheat the year before yielded only 5 bushels an acre, while wheat following maize yiekled 24.6 bushels.

The Soil Required. Maize demands a deep, and not exceedingly heavy, soil. It will never yield good crops where standing water comes nearly to the surface of the soil. Its soil must contain some sand. Maize should not be planted on very poor soil; because, while some plants will yield poor crops in such places, maize will usually yicld none at all. Maize takes much potash and phosphores from the soil. It has been found in Alabama that by plowing under some leguminous crope as beans or peas, the following (rop of maize could be increased by at least 50 per cent and sometimes by Ioo per cent. The plants of learumes contain the minerals that maize uses for food.

Fertilizers. In an experiment in (el)u, well-cultivated plants yiclded, without fertilizing, 3s.r 2 hektoliters per hektar; fertilizing with manure and bone ash raised the yield to $57.32 \mathrm{hl}$. The average crop in Cebu, with ordinary cultivation, is only ro hl. 
CULTURE

The Seed. The first step in maize culture is to secure the best possible seed. As a general rule, seed should be from plants grown under the same conditions as are

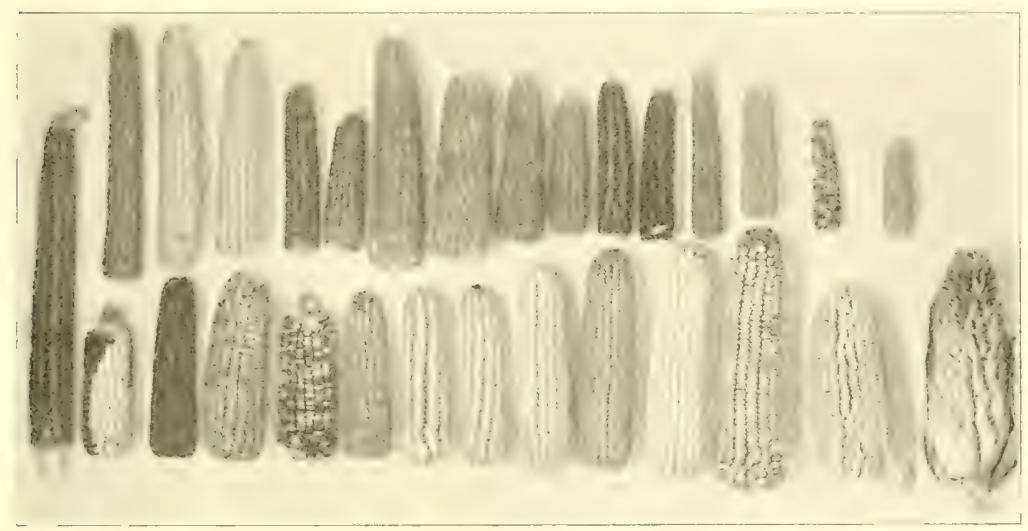

Fic: 73. Several varieties of maize

present where it is to be planted. If it is obtained from a great dintance, it may be excellent seed, but not adapted to the local conditions. It should be well ripened on the parent stalk.

Seeds should be taken only from plants with more than one good ear. Good ears are large, and covered to the end with regular rows of kernels; and the kernels must fit closely together. In gond cars, the grains have 75 per cent to 90 per cent as much bulk as the cob. There is much difference between varieties of corn. In a test of $3+$ varieties in Indiana, it was found that there were differences of 33 days in the time needed for 
maturing, and differences of ++ bushels of maize and 3.5 tons of fodder in the crop from I acre. An acre is about five twelfths of I hektar.

In an experiment at Ilagan, the following vields were obtained:

With yellow native maize, $22.8 \mathrm{hl}$ per ha.

With white native, $30.6 \mathrm{hl}$ per ha.

With horse-tooth, 41.2 hl per ha.

Horse-tooth is the commonest European starchy variety.

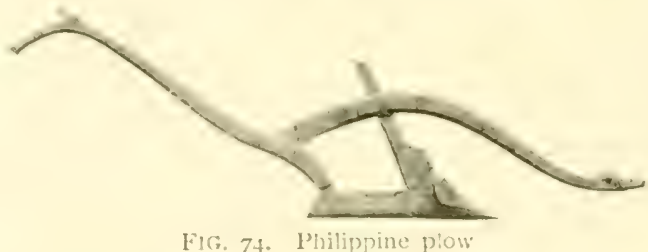

Preparing the Soil. Before the maize is pianted, the wround should be made clean and reasomably fine. On gered maize soil wery dexp plowing is umprofitable. The ceffect of plowing to different depths was tested in Illinois. () n a part of the field which was worked shallowly with a disk-plow, but not turned over, the yield was 56.4 bushels an acre.

Plowed $5 \mathrm{~cm}$ deep, the yield was 59.9 bushels.

Plowed ro $\mathrm{cm}$ deep, the yield was 69.4 bushels.

Plowed $1_{5} \mathrm{~cm}$ deep, the yield was 69.3 bushels.

Plowed $20 \mathrm{~cm}$ deep, the yield was 71.7 bushels.

In this case it was mprofitable to plow more than $10 \mathrm{~cm}$ (lece). But in an experiment in (ebu, rery deep plowing (subsoiling) almost doubled the yield. 


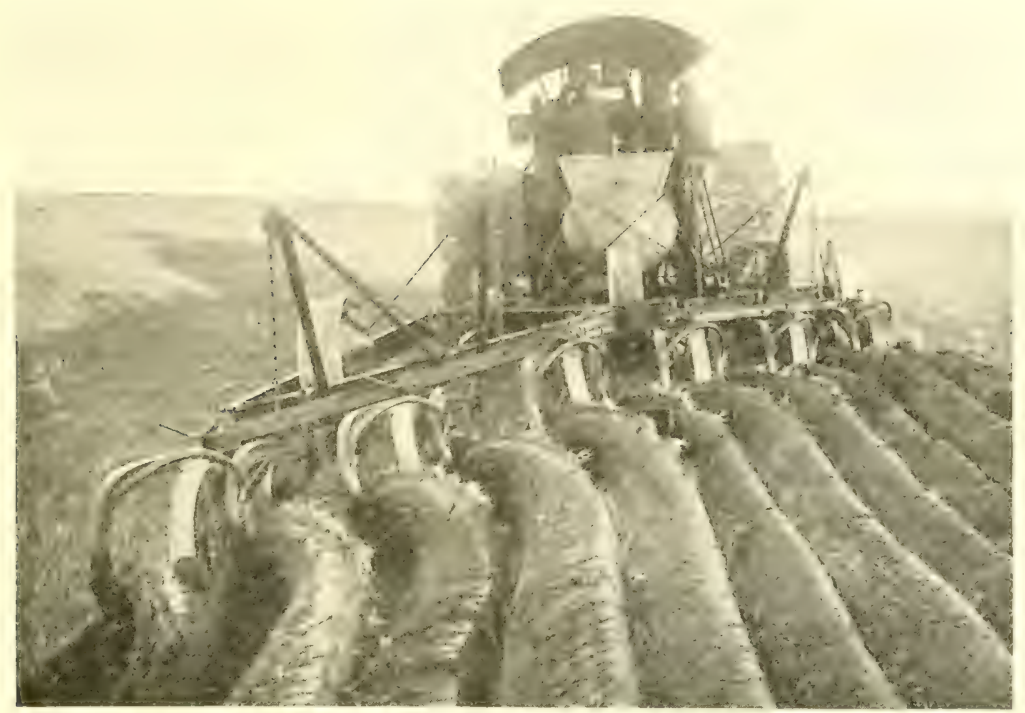

FIG. 75. Modern steam gang plow

Preparing the Seed. Before seed is planted in a field, its germinating power should be tested by an experiment with roo grains. This will show whether or not it is necessary to plant more than are wanted to grow. If many of the grains do not germinate, it is necessary to plant a larger amount of seed. Just before planting, the grain should be put for five minutes into water at a temperature of 55 . This will kill all fungus spores, and hasten the germination.

Planting the Seed. ()n small fields the grain can be planted by hand, of with a hand planter; but except on smail plots, it can be planted so much more rappilly and 
regularly with a seed drill that the latter method is the cheaper.

The depth to which the grain should be planted depends upon the wetness of the soil, and the weather. When conditions are as they

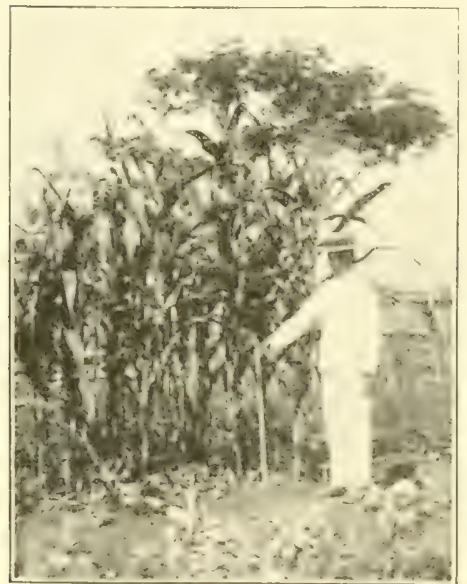

FIG. 76. Maize in the Philippine Normal School garden - cultivated should be, it will germinate well and grow if planted $8 \mathrm{~cm}$ deep. In wet soil the planting should be shallower. If in very wet soil, the grain will germinate best if planted only $2 \mathrm{~cm}$ deep; but maize so shallowly planted will not grow well. Therefore, it is best not to plant at all when the soil is very wet.

Hills. Maize is planted either in hills or drills. A hill is made up of several plants in a group); it should be perfectly level with the rest of the ground, at the time of planting. When the seed is planted in hills on fairly good ground, the hills should be I meter apart. There should be 3 plants in each hill; so pull out all plants abore that number, letting the best ones stand. On poor ground, it may be better to put the hills farther apart; and on rerg rich ground there may be + plants in a hill. The hills should be in straight rows in both directions, if the land is level. If the land is very sloping, the hills should be in rows which keep 
at the same level; this keeps the soil from washing away badly, and makes cultivation easier.

Drills. A drill is a row of single plants, at uniform distances apart. A machine which plants seed in this way is also called a drill. If maize is drilled into good ground, the rows should be I meter apart, and the plants $35 \mathrm{~cm}$ apart in each row. The directions just given are for planting maize for its fruit. If it is planted for fodder, the plants should be about onethird as far apart.

Cultivation. It is very important that maize should be cultivated the first time before the ground has time to become hard, and before the

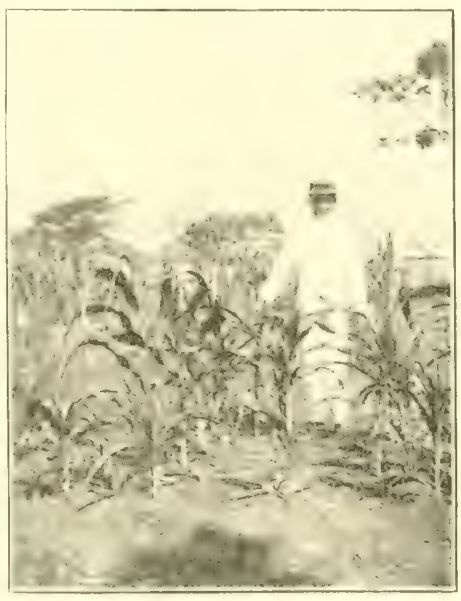

IIG. 77. Maize in the Plulippine Nurmal School garden - neglected weeds get well started; this will be while the maize is still very young. Figure 77 shows a field left too long before its furst cultivation. Naize does not répuire deep) cultivation unless the soil is badly in need of airing. Five cm is usually better than a sreater depth. Shallow cultivation is not only easier, but it is likely to yield a 25 per cent larger crop than very deep cultivation. If the weather is dry, frequent shallow cultivation helps the soil to retain its water.

In wet seasons, cultivation four times during the 
season is likely to give the largest crop, but it is usually more profitable to cultivate only three times. An experiment in New Hampshire showed that the crop was:

I 7.I bushels per acre, without cultivation.

69.7 bushels per acre, deeply cultivated, 5 times.

79.I bushels per acre, shallowly cultivated, 5 times.

So.6 bushels per acre, shallowly cultivated, I4 times.

Whe: the soril is first cultivated, it should be kept flat; but after the plants are a meter high, it is better to throw the soil up somewhat around them. Healthy maize grows most rapidly during the week or two after it is I meter high. It this time vigorous plants grow more than $10 \mathrm{~cm}$ in a day. 


\section{ハIイ゚IR XI}

\section{RICE}

Characteristics. Rice is the name of a grass and of its fruit. The botanical name of this grass is Oryza satiza. Like all grasses, rice has very small flowers, but its flowers are unlike those of most grasses in having six stamens. Each rice plant has a cluster of shoots, springing together from the base, and growing upward close together. In size, the different varieties of rice are very unequal. Some of the rice in Pangasinan is 2 meters in height; but the usual height is less than I meter. The roots are very fine.

History. Rice is a native of swamps, and grows in all the countries from Australia across southern Asia to central Africa. It was first cultivated in India or southeastern Asia. It is not known how long ago it was first cultivated; but we do

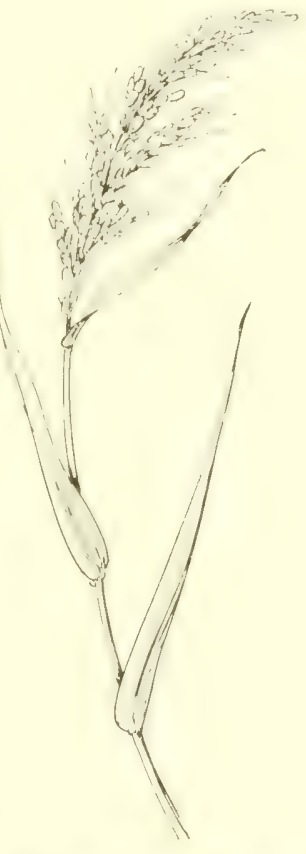

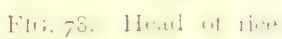
know that it was intreduced into (hina more than 4 ;oo years ago, and that it was cultivated in Babylon almost 103 
or quite as early. It was the staple cultivated crop of all the Malayan region before the time of Magellan.

Varieties. There are more varieties of rice than of any other crop. In India alone, there are supposed to be more than a thousand kinds. There were 15 I Philippine varieties in one exhibit at the Exposition of 1895 , in Manila. American and Japanese rice are the best in the world; of course there are many varieties in each of these countries. American rice sells in Europe at twice the price of Indian rice.

Japan exports great quantities of her fine rice, and imports more still, at a much lower price. Therefore, by raising a superior variety, the Japanese can consume much more rice than they produce, without the added amounts costing them anything. Experiments have shown that at least one kind of Carelina rice will grow in Manila, and produce a better rice in a shorter time than any kind already grown here.

Wild Rice. Mild rice, whether it is native or escaped from cultivation, is found wherever rice is cultivated. It always differs from the cultivated rice in having fruit which falls to the ground as soon as it is ripe. Also, the wild rice usually has long awns, or bristles, connected with the flowers; the shoots are prostrate rather than erect; and the leaf-sheaths are swollen up, and serve as floats when the water rises.

When wild rice gets into a field with cultivated rice, its seed falls to the ground before the crop is gathered, and so is lost. Unless it is killed in some way, this wild 
rice seed grows the next season, and again sows its seeel, and so keeps taking more and more room in the field. Because it thrives on exactly the same treatment as the cultivated rice, and looks much like it, but sows all its seed in the field, wild rice is by far the worst weed in rice fields.

Production. Rice is a very important crop in all warm parts of the world except tropical America. Its greatest production is in southeastern Lia, and the greatest riceexporting cities are Rangoon and Saigon. Java supports its population of $30,000,000$ chiefly on rice, and still exports a great deal. In the United States the production of rice is increasing very rapidly; Texas is the foremost state in its production.

In the Philippines, every province produces rice; Pangasinan, which in some years produces as much as four million pesos worth more than it uses, has the first place. Rice has been imported into the Philippines the most of the time for fifty years.

Value and Uses. Rice is the staple or chicf food of the people from the lowlands of India to Japan and Polynesia; it is probably the staple ford of more human beings than is any other one grain. A great deal of rice is also eaten in the other parts of the world. It is regarded as an especially good staple food in hot countries, because it contains very little fat.

The rice grain contains, besides the ash, about I 2.8 per cent of water; 78.3 per cent of starch; 7.3 per cent of proteid; and 0.6 per cent of fat or oil. It is sometimes 
used as a source of starch, but rice starch is neither the cheapest nor the finest. Rice is sometimes used as a medicine for dysentery; and water in which rice has been cooked is commonly used in this way. In most countries which produce it, rice is used in making alcoholic drinks. The straw has various uses, the most important of which is as a fertilizer on the fields where it grew. Rice straw also makes a fine paper, but it is not the source of most so-called rice paper.

\section{CONDITIONS OF GROWTH}

Heat. I ifferent varieties of rice make very different demands on the climate. Most varieties require at least four monthe of hot weather, with an averagetemperatues above 22. Cold nights cannot be endured, even though the days be warm and bright. Some varieties require six months to mature, while a few poor ones mature in three months after planting. There are other varieties, of excellent quality, which endure a uniformly lower temperature: but these require a long season and very careful treatment, and so are an expensive crop. Rice is cultivated northward to $32^{\circ} \mathrm{in}$. Imerica, and farther in Japan. Its upward limit in the Philippines is an altitude of about I 500 meters. No crep) requires more light than rice; it will endure no shading at all.

Soil. If it is properly supplied with water, the quality of the soil makes less difference to rice than to most crops. It usually does best on rather light soils; but the soil must of contre not be so sandy as to be deficient in 


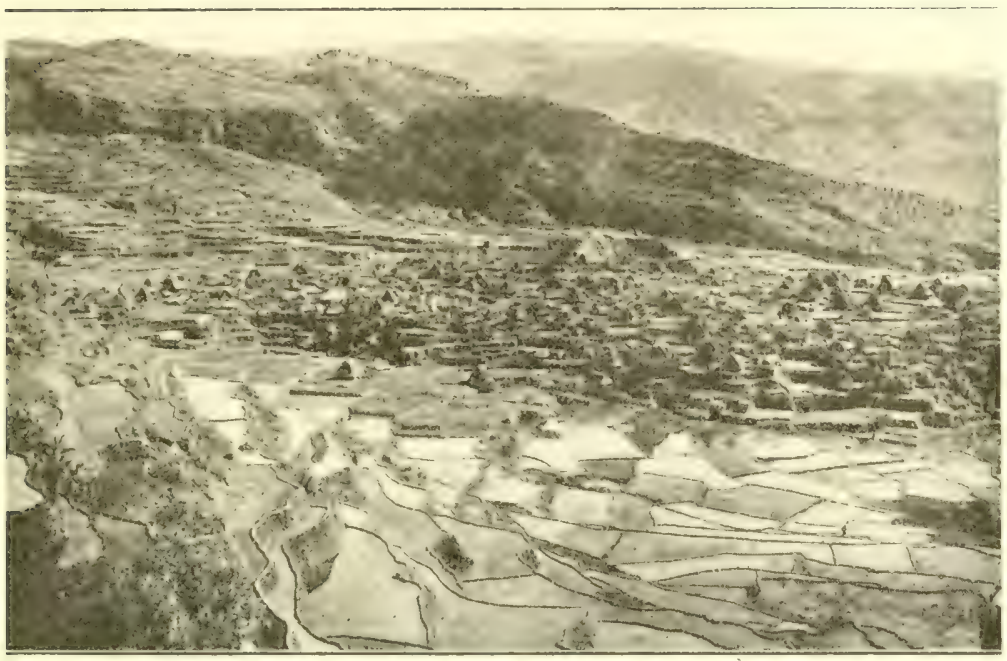

Fiv. 79. Terraced rice paddies of the Igorots

food for the plant. Phosphorus is the food of which rice most often has too little.

Water. With regard to its need of water, two sorts of rice are distinguished - upland rice and water rice. The upland rice thrives on soil which is light and well aired. It does not require wetter soil than other crops; but it does require moist air. Where the air is dry, it produces so little fruit that it is better to plant some other kind of grain.

The water rice requires more water than does any other important crop. This water is almost always supplied and regulated by irrigation. The ways in which the water is supplied, the times at which it is put on, and the length of time it is left, are very different in different 
places. Standing water is always left on the ground a considerable part of the time while the rice is growing. When the water gets too hot, or becomes full of harmful plants or animals, it must be run off. After the time of flowering, the fields are permitted to become dry. While the rice is ripening, dryness helps the maturing of the grain, and makes it easy to harvest it. Each plot or field of rice must be rery level; for otherwise the different parts will not be equally watered, and will not mature together.

\section{CULTURE}

Methods of Planting. Ground in which rice is to be planted must always be made thoroughly fine and smooth. It is not necessary that the ground should be worked especially deep, but no crop needs fincr soil. There are three very different systems of planting rice: scattering or broadcasting the seed, drilling the seed, and transplanting.

Broadcasting. Broadcasting is the Italian method of planting, and is used with upland rice in almost all countries. It is the experience of famers in the Philippines, however, that water rice sown broadcast requires I 6 per cent more seed, and will yield at least 20 per cent less than could be olotained from the same ground by transplanting.

Transplanting. Transplanting is known as the Chinese method of rice culture. It is in general use in the Philippines and throughout the ()rient. The seeds are planted in thoroughly worked and enriched seed beds. This 
methes of cultivation makes it possible for the rice to be geminating and growing while the paddies, or fields. are being prepared. But it can be used only on a small scale and where human labor is very cheap.

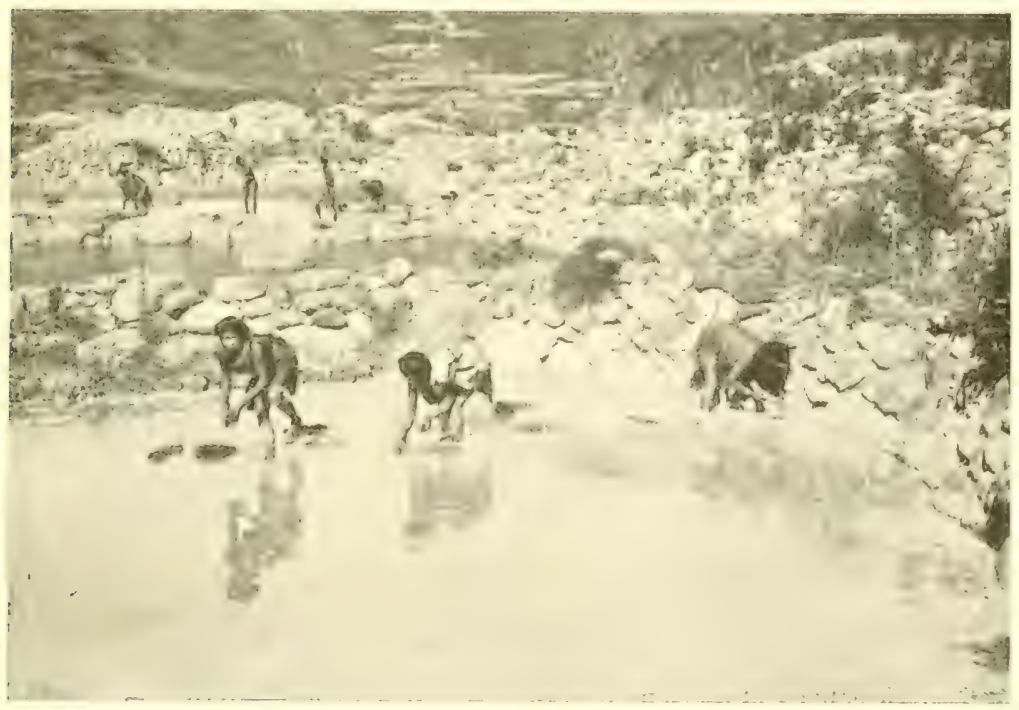

FIG. 8o. Women transplanting rice plants in the Igorot country

The padcies are usually cultivated in the state of soft mud, which prevents the use of any beast except the (arabzo. Rice plants of the ordinary size are set in the paddies about Io $\mathrm{cm}$ apart in each direction.

Drilling. I) rilling in the seed is the Imerican method, furst developed in South Carolina, and now used on a very large scale in Texas. Machines are used which plant the rice seed in straight rows, at uniform distances apart. Water is then turned on the fields and left until 
the first leaves appear. The field is then left without water until the plants develop the second leaves, or sometimes until they are $20 \mathrm{~cm}$ in height, when the water is turned on again and renewed as often as necessary, perhaps once in $\$$ days, until after flowering time.

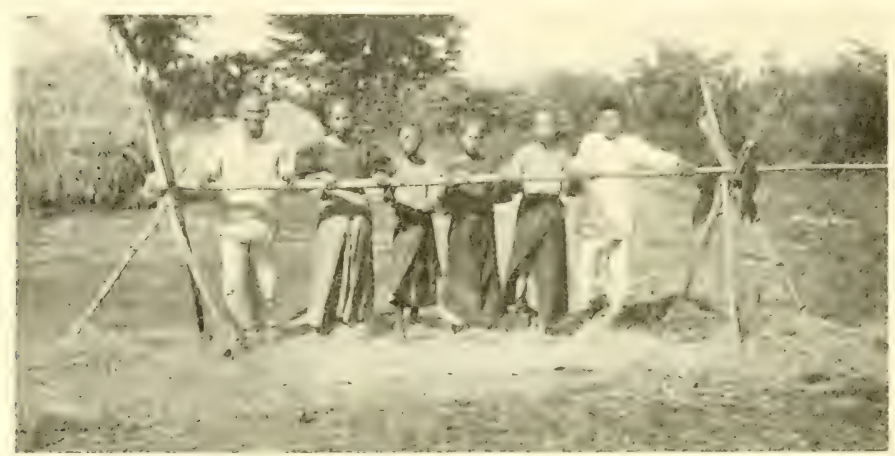

FIG. 8x. An old way of threshing rice in the Philippines

This method of culture is very much cheaper than transplanting; and, since but little rice fails to germinate, gives very nearly as large returns. American planters expect to harvest so grains for every grain planted. The large drilling machines used in Texas, which plant many rows at once, could not be used on the small paddies in the Philippines. But there are cheap hand drills which sare a great deal of labor, and can be used on the smallest plots.

Harvesting in Texas. The rice is also harvested in Texas by great machines, each cutting a strip several meters wide, and threshing and sacking it at the same 


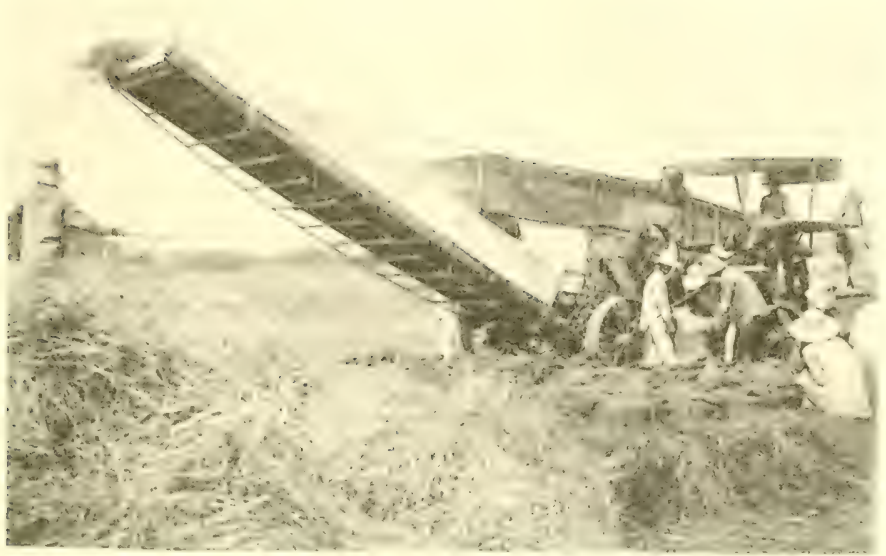

Fin, 82. A motern rice thresher in the philippines

time. These machines are very expensive, and cannot be used on small fields, such as are found here. But it is possible in many places here to use threshing machines after the rice is cut. One such machine can thesh all the rice in a large community. Every laborer in the Texas rice fields is paid three pesos a day, or more. And yet, by the use of machinery, rice is produced there more cheaply than is possible in the P'hilippines. 


\section{CHAPTER XIII}

\section{SUGAR-CANE}

Sugar is obtained from many different plants, but two alone, the sugar beet, which grows in the temperate zones,

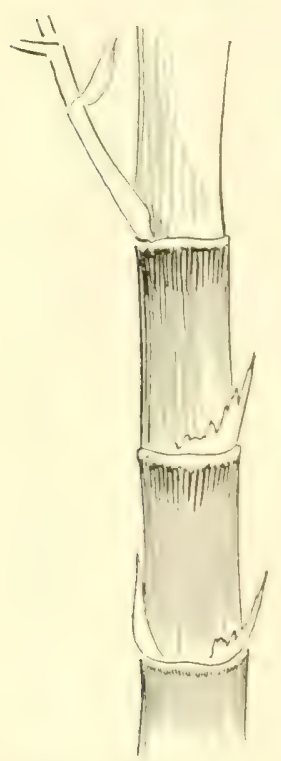

Fig. 83. Stalk of cane showing nodes and internodes and the sugar-cane, furnish all the sugar that is used as an article of commerce.

Description of the Cane. The cane is a large grass, usually 2 or 3 meters, but sometimes as much as 6 meters, in height. The erect stems are 3 to $5 \mathrm{~cm}$ in thickness. Like all stems they are made of alternate nodes and internodes. At each node is a leaf, and in the leaf's axil is a bud, which is called an eye. Roots also can spring from the nodes, but do so only near the ground.

The internodes vary in length in different varieties of cane, from 5 to $7 \mathrm{~cm}$ to 20 to $22 \mathrm{~cm}$ in length. Since it is in the fleshy internodes, not in the hard nodes, that the sugary sap is found, it is well for the internodes to be long. The internodes in the middle are longer than those near the ends.

Besides the erect stems, there are underground stems, 
which differ from the erect ones in having very short internodes. The erect stems do not usually branch, unless near the base, but the underground ones branch freely, and give rise to clusters of erect ones.

The topmost internode sometimes grows out rapidly to a length of 90 to $120 \mathrm{~cm}$, bearing at its top a panicle of flowers. Most of the cultivated varieties never flower, and those which doflower rarely bear any seed. The seed is never used to reproduce the plant, except for the sake of getting new varieties.

History of the Plant. The betanical name of cance is Sacchamm officinamu. The plant does not grow wild, and it is very probable that it is only a cultivated form of an uncultivated grass common in India and Malaya. This is Saccharum spontancum, which is called talahib in Tagalog and tighao in Bisayan. The carliest rultivation of cance was certainly in India, and was excecedingly ancient. The plant was introduced into China at least sixteen hundred years ago, and was grown all over the Malayan region before the arrival of Europeans. The Moors took it into Europe in the eighth century; and the Spaniards took it to the West Indies in the sixteenth century.

Varieties of Cane. The cultivated raricties of cane are exceedingly numerous, and the same ones have different names in different countries. Among the most important varieties are the following:

I. Bourbon cane, also called Yellow Otaheite: This is a big, rich cane, usually straw-yellow in color. It 
is said to degenerate, or become poor, in long cultivation; but this is probably due to bad treatment.

2. Otaheite Ribbon cane, or Striped 'Tanna: This also is a rich cane, but the sugate is not always perfectly white. The internodes are yellowish, with bluish or purple stripes. This and the preceding variety are the most popular varieties in almost all countries.

3. Java Transparent: This is a quick-growing cane, with internodes 10 to $20 \mathrm{~cm}$ long. which hear hlood-red stripes. It is an excellent variety for light ground. selangore is a similar or identical canc, common in Malaya.

4. Black Java: 'This has purplish or black internodes 8 to $15 \mathrm{~cm}$ long; or, toward the top, it may be striped. It endures bad treatment better than other canes, and produces a sweet sap. But the sap is not abundant, and the cane is too hard to mill very well.

5. Elephant cane: "There are several canes with this mame, of which the Conhe China likephant rane is the largest and hest known. This wants a rode soile and is too brittle to mill well.

\section{PRODUCTION}

Production in the World. The amount of canc sugar produced in the world has been:

YIAR

I 853

I 870
Tons (IO00 kilograms)

I, 260,400

I, 340,980

$1,740,493$ 
YEAK

ToNs (1000 kilograms)

$\begin{array}{llll}1850 & \cdot & \cdot & 1,988,859 \\ 1859 & * & \cdot & 2,453,3+2 \\ 1900 & * & \cdot & 3,350,000\end{array}$

These figures do not show how rapidly the use of

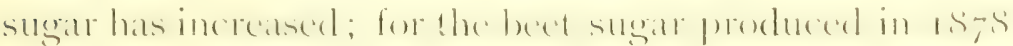
was only half as much as the cane sugar, but was twice as much as the cane sugar in I goo. The amounts of cane sugar produced in some places in 1900 were these:

P'IAT:

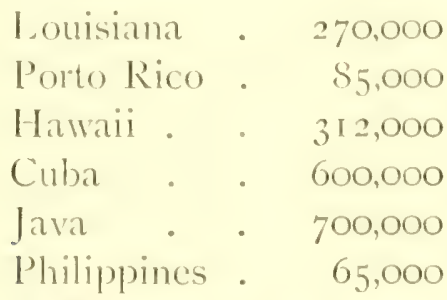

Production in the Philippines. The slight production in the Philippines was a result of war. The export from the Philippines at different times has been:

\section{PVIRIOI)}

I\$52 to $1 \$ 63$ average

1863 to 1872

IS73 to I $\$ 83$

I $\$ 83$ to $1 \mathrm{Sg}_{2}$

ISg3 (the maximum).

isos

1900

1902

I 906
ToNs

55,000

71,000

136,000

187,000

262,000

177,000

65,000

99,000

I 23,790 
The foremost of the islands in the production of sugar is Negros, and the foremost province in Luzon for its production is Pampanga. 'The United States consumes more than half of the cane sugar from the world's markets.

\section{CONDITIONS OF GROWTH}

Heat. Cane is distinctly a tropical plant. It grows north as far as 32 in the United Stater, and beyond 360 in Spain; but its cultivation in these places would be unprofitable if it were not for protective tariffs, which conable those who grow it to get high prices for all they produce. Frost kills cane promptly. The temperature should be high and uniform. In the Philippines it grows at an altitude of at least 1200 meters, but it is not raised on a large scale except in the lowlands.

Moisture. A moist air is usually regarded as very necensary for the vigerous growth of cane; and the climate of tropical inlands, because it is uniformly warm and moist, is said to be the best possible for sugar-cane. Unless the cance is irrigated, it will not reach its best develepment where the rainfall is lens than 2 meters during the year, nor where there is any dry season while the cane is growing. I drought before the growth is complete, results in plants with little sap, which is poor in sugar. However, a dry season while the cane is maturing is advantageous, if the crop is gathered before it turns brown.

Soil. Good sugar soil must contain abundant lime, nitrogen, and phosphorus. It is posisible for a soil to con- 
tain too much nitrogen, but this very rarely happens. some potassium must, of course, lxe present (sece page 26); but too much potassium or solium makes a soil bad for sugar. If a soil contains a little too much of these, some can be removed by growing maize on it for a year or two.

When sugar is grown for a long time on any plot of ground, it is likely to exhaust the lime. This has happened on some Philippine plantations. Semler, in his book on tropical agriculture, describes a soil from Camarines as the finest possible for sugar.

\section{CULTURE}

Propagation. Cane is always propagated on plantations in one way, by burying a part of a grown stem in the ground. This piece is usually laid horizontally, in well-broken ground, and buried under less than a decimeter of soil.

One method is to use whole stems for "seed," FIG.84. Apex of and to lay them end to end in the rows; but stem showing this method wastes a great deal of sugar. The and eyes better way in to use only three nodes from the top of the cane, where the internodes are short and contain very little sugar. These tops are placed about $80 \mathrm{~cm}$ apart in the rows, and the rows are I meter to I $20 \mathrm{~cm}$ apart. Small cane may be planted closer than this, and very large cane should be farther apart. The rows are sometimes made farther apart to permit cultivation by 
machinery. In the Philippines, cane is usually planted much more closely than this.

Selection of Cane Seed. The cane used for "sced" should be selected from the most productive plants, and should always be the first year's growth from the planted cane. Because many planters do not select their "seed," their cane is not as good after a few years as at first. Any good cane will degenerate unless the seed-cane is carefully chosen.

Cultivation. The young leaves appear above the ground within two weeks after planting, and it may be necesisary to cultivate immediately. The amount of later cultiration needed by cane depends altogether on the conditions. () course, the ground must be kept reasonably soft and free from weeds. In most places it is sufficient if the cane is well cultivated twice within the furst three or four months.

Irrigation. The need of irrigation is likewise dependent on conditions. Is a general rule it pays to irrigate cane wherever the annual rainfall is less than 2 meters, and also wherever the rainfall is not well distributed through the growing season. Although growing cane needs water constantly, it cannot endure standing water about its roots. In many places the same ground which is irrigated must also be well drained. The irrigating canals and drainage ditches may also be used to float the cut stems on boats or rafts to the mill.

Maturing Cane. When growth is practically done, and the cane is maturing, the soil should become dry, both 
because dryness hastens maturing, and because unnecessary water in the sap adds greatly to the cost of evaporating it. Canc is mature when many leaves begin to turn yellow or brown. After this time the sugar decreases rapidly; and before this time there is considerable glucose present with the real cane sugar. This glucose is a kind of sugar which not only will not itself crystallize when the sap is evaporated, but also prevents the crystallization of an equal

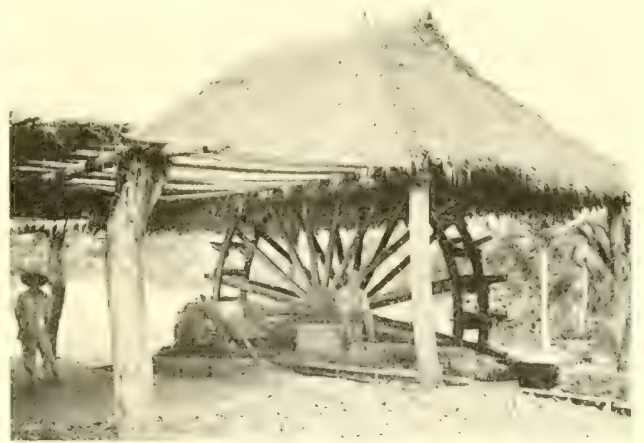

FIG. 85. Philippine sugar mill driven by water power amount of the cane sugar. Sodium and potassium in the sap also interfere with the crystallization of the sugar.

Ratoon Crops. Except under very favorable conditions, cane is not ready to cut until fourteen months after planting. Ifter the erect stems are cut, a new crop will grow from the underground stems. This is called the first ratoon crop. Second and third ratoon crops can be raised in the same way. In Java and also in Pampanga, it is customary to replant the cane for each crop. In most countries it is planted about every third year; but on one Hawaiian plantation cane was cut for nine years without replanting, and with excellent results. The ratoon crops usually mature within a year. 
Plan of Plantation. When two ratoons are used, a plantation should be divided into at least three parts. One of these is replanted each year, and the stem-tops of the preceding year's planting are available as seed. A still better arrangement is to

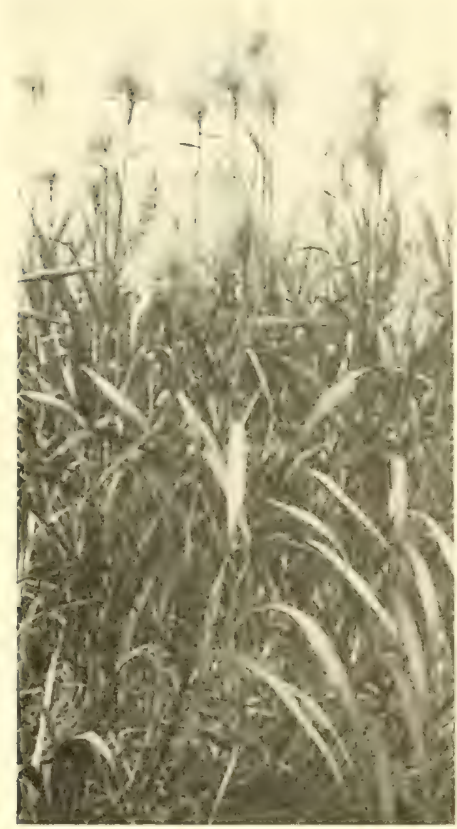

FIG. 86. Clump of cane in Hower divide the plantation into four parts, and let one part rest, or raise a different crop on it each year.

Sugar Miaking. The cut cane, stripped of its leaves, is carried to the mill and crushed, and the sap is evaporated. The crushed stems are treated with water, and crushed again; and sometimes this is done a third time, and all the water squeezed out is evaporated. The sugar obtained in this way is crude, or coarse and brown, and must be refined to make the fine white granulated sugar in common use.

Waste. Somesugar is always left in the stems of cane, and with poor machinery a great deal of sugar is lost in this way. The waste from the mill, left after the stems are crushed as dry as possible, is called bagasse. Bagasse is a good fertilizer, usually needing also only a 
little phosphorus and lime to keep up the full fertility of the soil. Bagasse is often used as a fuel to run the mill. The ashes are then used for a fertilizer. Nitrogen, phosphorus, and lime should be added to the ashes to keep the soil from becoming worn out. 


\section{CHAPTER XIV}

\section{THE COCONUT}

A Member of the Palm Family. The coconut belongs to the palm family of plants, which includes also the palma brava, betel nut, nipa, buri, and cabo negro. Its botanical name is Cocos mucifera. There are about thirty-five other species in the genus Cocos, and all are natives of America. It is, therefore, almost certain that the coconut came from America; but it was found in very ancient times on the tropical coasts of the Old World. The nuts often fall into the sea and float, and if they are thrown ashore before too long a time, they
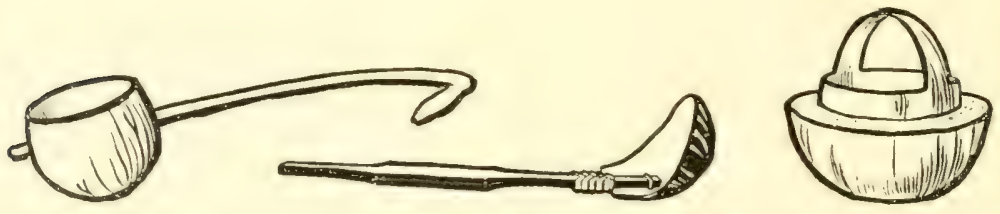

FiG. 87. Some things made from coconut shells

can grow. In this way the plant can spread to new shores.

Uses of the Coconut. The coconut is useful in more ways than any other tree in the world. The natives of Polynesia are said to use it in more than a hundred different ways. The most important commercial product 
of this tree is copra, the dried meat of the fruit. The fiber of the husk, called coir, is another very valuable product. In the Philippines the leaves and trunk are uned in building holines, the huskis and shells for fucl, and the shells in making household utensils. There are still other local uses for various parts of the tree. The rich sap, fermented, is tuba. The oil obtained from copra has many local uses.

The Roots. The roots of the coconut are ceceedingly numerous; sometimes as many as eight thousand grow from the base of one trunk. They are all very slender and elastic. They grow only near the surface of the ground, and, in general, grow straight ahead in the direction in which they leave the stem. The longest are about 7 meters long in sand, or about 5 meters long in firm soil. The root branches grow at right angles to the main roots.

The plant is without really fibrous roots, and without root hairs. Only the youngest parts of the roots, just behind the tips, absorb water. The old parts are incased in a thick, hard shell, which prevents their losing the water absorbed by the young parts. The short, sharp, white roots scattered over the old ones are breathing organs.

The Trunk. The trunk of the coconut is very hard on the outside, but softer within. It is so tough that no ordinary wind can break it. The trunk is enlarged at the base so as to have place for the attachment of its many roots. 
- After the first few years, the stem does not increase in thickness, but it grows in height as long as it lives. It usually grows straight upward; but if one side receives

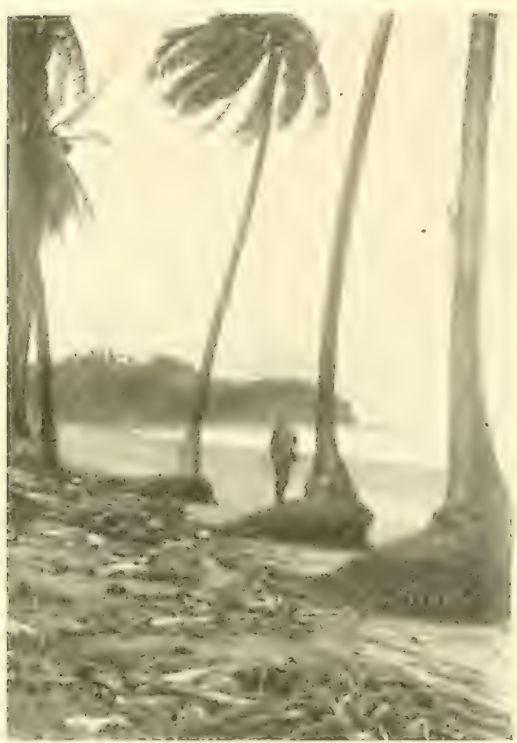

FIG. 88. Coconut trees on the sea-shore, $\mathrm{Pa}$ citie coat of layath provmen, showing the enlarged base and numerous roots more light than the other, it bends toward the side most lighted.

Leaves. An old, strong tree has twenty-five to thirty-five leaves, each 5 to 7 meters long, with about eighty pairs of leaflets. The leaflets are folded downward. There is a hinge along each side of the midrib. When the leaf transpires faster than it can get water, the hinge causes the edges to fall and fold nearer together, and this checks the loss of water. Each leaf lives a little less than two years. Like the stem, the leaves are very tough.

Flowers and Fruit. The flowers are borne in dense panicles, one panicle in the axil of each leaf. The flowers do not open until more than six months after the first appearance of the leaf in whose axil they grow. The staminate and pistillate flowers are distinct; and in each panicle the staminate flowers wither and fall off 
before the pistillate flowers are mature. The pollen is carried by insects. It takes nine months or more for the fruit to ripen.

Describe fully the fruit of the coconut.

Find the average weight of five coconuts.

What is the average weight of the husks?

What is the average weight of the fresh meat?

What part of this weight is left when the meat is air-dried?

\section{PRODUCTION}

The product of the

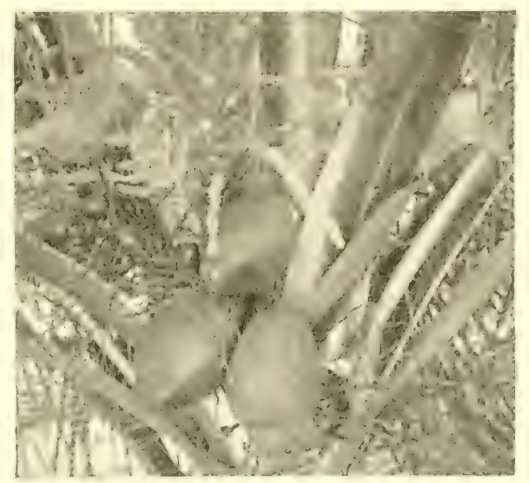

Fici 89. Fluwers and fruit of the coconut tree coconut is marketed in so many forms that it cannot be measured in any one way. The comparative product can be judged, though, by the acreage. The number of hektars of coconuts in some lands in 1896 was:

\begin{tabular}{|c|c|c|c|c|}
\hline Ceylon & & & • & $27 \mathrm{I}, 000$ \\
\hline India . & & & • & I 46,000 \\
\hline Java and Sumatra & & & . & 92,000 \\
\hline Polynesia . . & & & & $\mathrm{IO}_{4}, \mathrm{OOO}$ \\
\hline outh America. & • & . & • & 208,000 \\
\hline entral America & & . & . & 104,000 \\
\hline
\end{tabular}

According to the Census of I903, the number of hektars of coconut plantations in the Philippines in 1902 was I 48,245 . 
Coconuts and their products yield the chief exports from Ceyton, Polynesia, and a large part of Malaya, and are a very important crop of every tropical country. In the Philippines, the best coconut district is about the base of Mt. Banahao, in Laguna and Tayabas. Copra ranks third in value among the Philippine exports, and is increasing in importance.

\section{CONDITIONS OF GROWTH}

Heat. The coconut is distinctly a plant of the torrid zone. It grows as far north as Florida and produces fruit, but not enough to be of any value. It must have a very uniform temperature, which must average about $22^{\circ} \mathrm{for}$ the year. An altitude of 500 meters is probably the highest limit of its profitable culture, even for local use, in the Philippines.

In these islands the coconut is never injured by heat, howerer great. In direct sunshine the leaves become much hotter than the air about them, and this greatly increases the transpiration. Once when the temperature at San Ramon was $28.3^{\circ}$ in the shade, and $31.5^{\circ}$ in the sun, that of a coconut leaf in the sun was $38^{\circ}$.

Light. The coconut needs much light, as well as a high temperature. Without more light than most plants need, it will bear but little fruit. The tree thrives best on the seashore, where it receives more light than in any other place.

Tell, in figures, what effect the amount of light has on the production of nuts. The answer is given in Chapter V, Plants and Light. 
Moisture. Since it has no fine roots and no root hairs, the coconut cannot get the water it needs, cxcept from a very moist soil. It needs a uniformly distributed

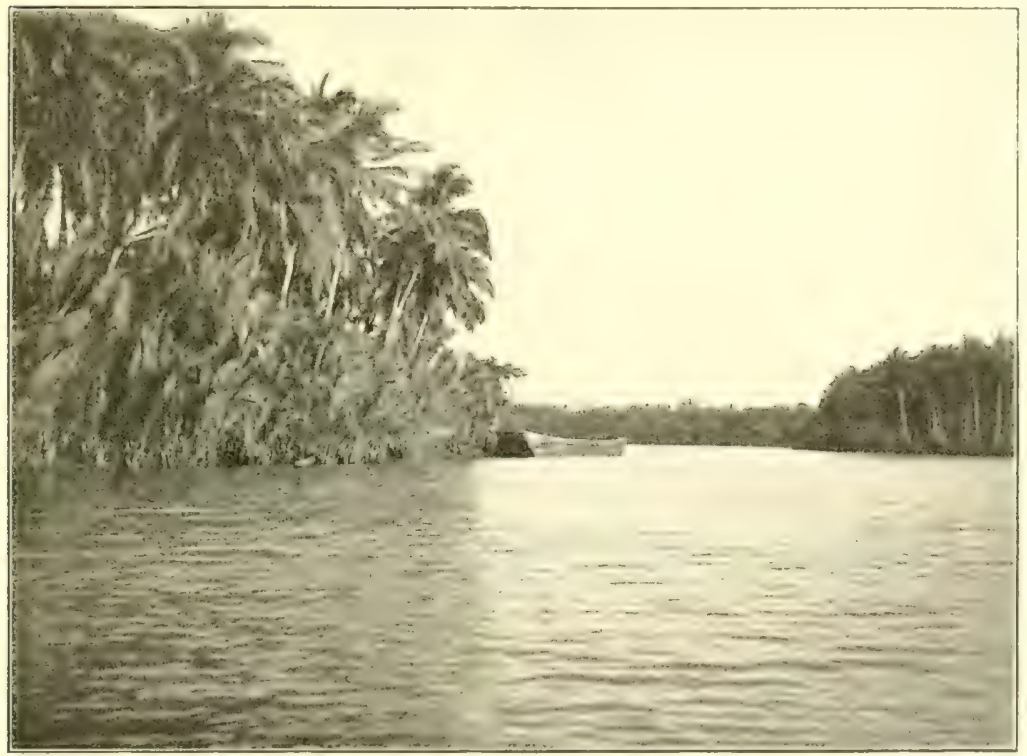

FIG. 90. Coconut groves along the Dumaka River, 'Iayabas province, with nipa at the water's edge

rainfall of as much as $20 \mathrm{~cm}$ in the year; or else it must be irrigated; or there must be more water in the ground than is due to the local rainfall. Along sea beaches there is always water in the ground, which flows slowly from higher land through the soil to the sea. Fnough of this water moves upward through loose soil so that trees in this situation are less injured by dry seasoms than are trees anywhere else. 
Injury caused by Drought. A dry season injures the coconut for a longer time than it does any other crop which is not killed by it. When the ground about the roots becomes dry, the roots cease to grow, and the absorbing surface decreases. The resulting loss of water promptly checks the growth of the young leaves, and of the branches which bear the nuts. It does not delay the ripening of the nuts already growing: therefore, it is nine monthis or more after a clrought begins, before the crop is injured by it.

When the rains begin after a drought, the roots begin to grow again; after they become active, the leaves can begin to beso. Since it is usually eighteen months from the first appearance of a leaf to the ripening of the nuts in its axil, the injury done by a drought is not all shown until at least eighteen months after the drought ends.

Dryness hurts the coconut in several ways which there is not time to study here. A bad dry season only as often as every other year will keep the crop down all the time to 40 per cent of what it ought to be. Therefore, coconuts cannot be srown profitably without irrigation, where very dry seasons occur.

The Soil. While the coconut must have a moist soil, its roots will not grow into soil full of water; and if they are covered too long by water, they die.

The coconut will grow in poor soil, but it will produce few nuts there. It produces fine crops on poor beach soil, because the water which the roots take up has come through richer soil, and is well supplied with food. 


\section{CULTURE}

Selection of Seeds. Ciconuts to be used as seed should be picked from trees which are conspicuous among their neighbors growing under the same conditions for producing large nuts, and many of them. There is no reason

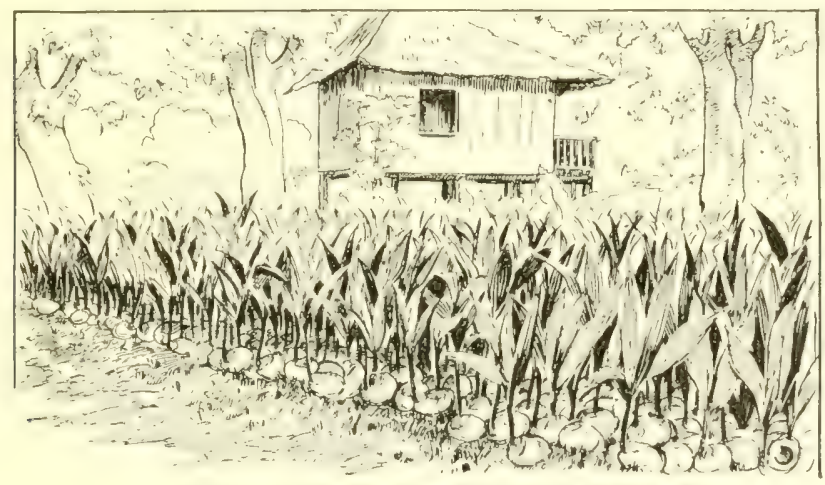

1.11: y I. Civenuts gemmating in sered furd

for selecting seed from prolific trees which are prolific simply because they grow in especially good places; for then the productiveness is not a character of the tree, but of the place, and the place cannot be inherited. It is best not to let the nuts of an especially goosd tree fall to the sround, because some of them will crack. Neither is it a good plan to select large nuts out of a pile; for a tree with very few nuts often has especially large ones.

Germination. Coconut seed are germinated above ground and are not planted until the roots and plumule appear. Seed nuts may be hung up in bunches in wet weather or stacked under a shelter and watered; lout the 
best and easiest method is usually to lay them on the ground in the shade. In dry weather, water must occasionally be thrown over them. The trees are likely to be more robust if the nuts are laid on their sides, instead of being stood on end. The young shoot will be more

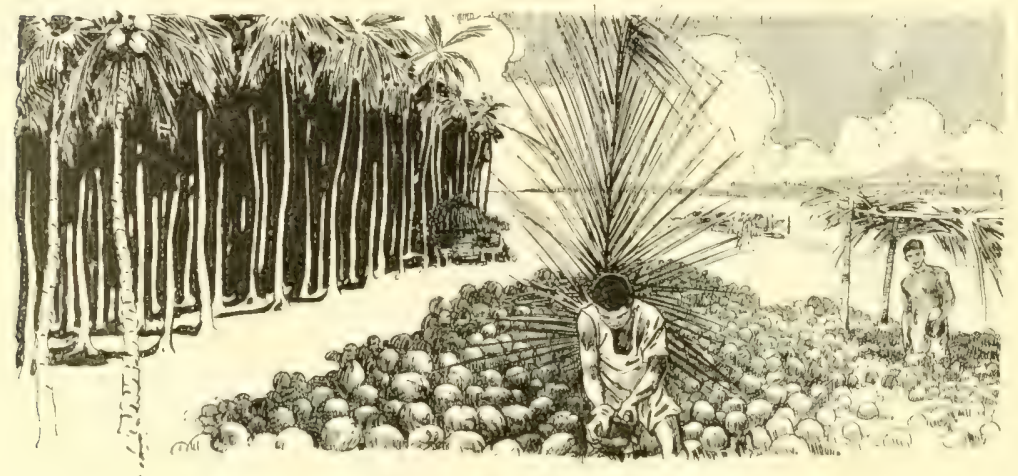

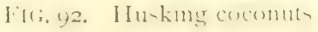

likely to be straight, if, where it is to come out, a little of the outside of the husk be remored. Some nuts germinate within a month, others need four or five months.

Planting and Cultivation. It is best to plant the nuts in their permanent places before the sprout is $50 \mathrm{~cm}$ high, and before they become fastened to the ground hy a strong set of roots; otherwise breaking these roots will seriously check the growth. When they are planted, a part of the nut should be left above the ground. In large groves the trees ought not to be less than $S$ meters apart.

Cultivation, at least to the extent of keeping the ground 
clean, will pay for itself in the early maturing of the trees.

The ground used for coconuts is often very poor, and should be enriched in every way possible. While the trees are young, other crops can be grown with the coconuts, but care must be taken not to make the ground poor in this way. Notches should not be cut in young trees; nor should they be deeper in the older trees than is really necessary.

The Crop. Trees sometimes bear many nuts by the

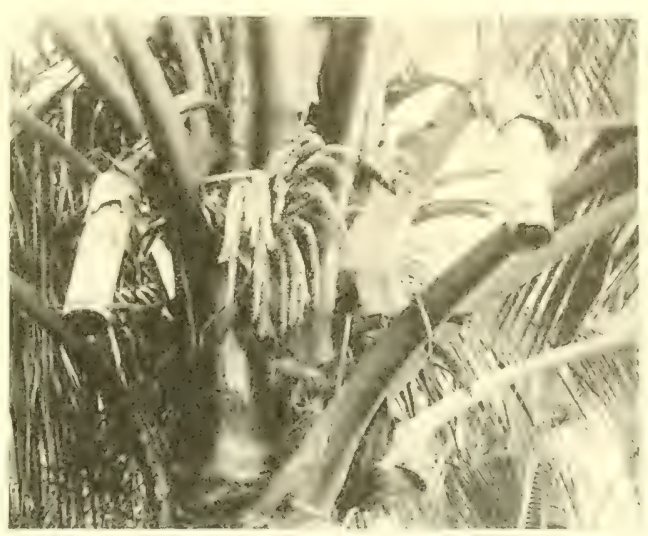

FIG. 93. Method of collecting tuba in bamboo cylinders time they are five years old, and a good crop should be obtained in about seven years after planting. A tree ought never to bear less than 50 nuts in a year; and twice as large an average as this is possible. At sian Ramon, Iooo nuts are expected to yield 5 piculs of copra; but in Laguna they do not yield more than 3.5 piculs. After the nuts are cut, there is likely to be a slight increase in the oil, if they are not opened at once; but it is not safe to leave them more than one month.

The Products. The work of opening the nuts and drying the copra is too well known in the Philippines to need 
description here. If the copra must be dried by fire in. stead of by the sunshine, it should be kept free from smoke. The collection of tuba is even better known in the Philippines than the making of copra. Coir is a valuable product which is usually wasted. It is a remarkably elastic fiber, but that of old nuts is very coarse and harsh. It must be extracted by machinery, alid this cannot be done profitably on a small scale. 


\section{CHAPTER XV}

\section{FIBER PLANTS}

\section{$\triangle B A C A ́$}

The Banana Family. Dbacá is the name of a plant, Muser tivlilis, and of the fiber extracted from this plant. Muser is the banana genus, and abacá and banana plants

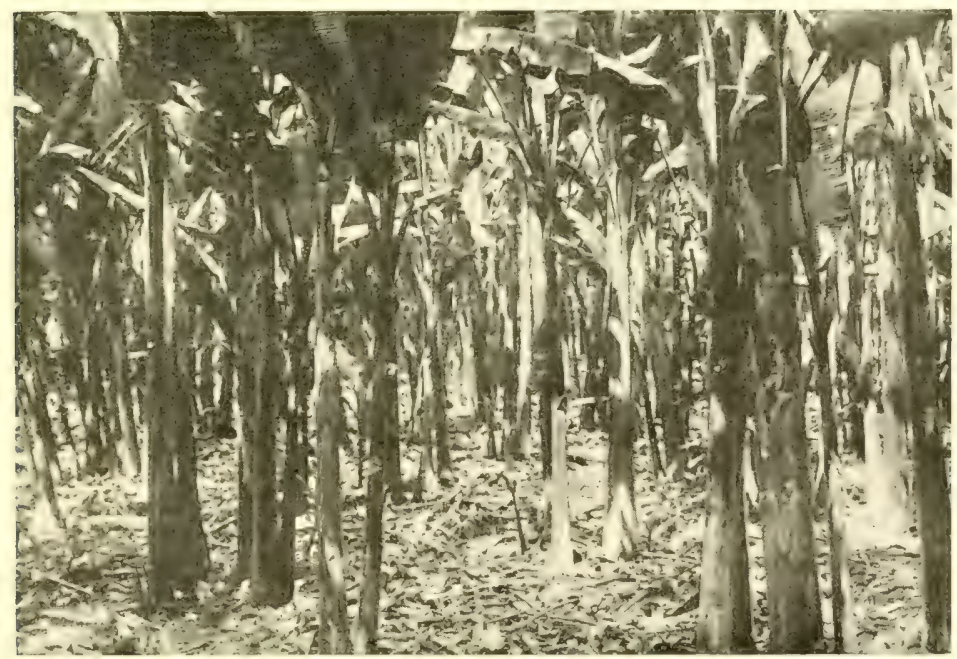

FIG. 94. Field of abacá in Albay

are very much alike. They have no very large roots, but many small ones, which do not run very decply into the ground. There is a short, branching, underground stem, but the real erect stems do not become tall until the 
plant is ready to blossom. Young erect shoots, or suckers, grow at all times from the underground stem, so that an old plant has ten to thirty shoots of all ages, in a cluster.

What looks like a stem is made up of the leaf bases. These are broad and oxerlapping. They grow up, one inside another, until they make an apparent trunk 30 or $40 \mathrm{~cm}$ in diameter. The real stem, which grows rapidly up through the midclle of the false stem, is usually less than $8 \mathrm{~cm}$ in diameter, and contains no useful fibers. The flowers of abacá are borne in clusters on a thick axis. The clusters nearer the base bear the pistillate flowers; they blosiom before the staminate flowers open. The pollen is carried by insects.

Abacá Fiber and its Uses. The fruit of aloacá is smaller than that of most bananas, and contains many large seed. The fibers are found in the leaf bases which make up the false stem. In the outer part of each base, the fibers are more numerous, and their cells are much longer and thicker-walled than those of the inside fibers. The outside fibers are therefore a great deal stronger.

The principal use of the abacá fiber is in making cordage; for this use it is the best fiber produced in large quantities in the world. Abacá is very strong, but so light that it will float on water. For these reasons, the cordage used on ships in all countries is usually made of it.

In the Philippines, the finest abacá is used in making cloth, most of which is called sinamay. Far more sinamay is made than any other cloth. Exceedingly strong 
and heary cloth is made of abacá in some places. Hhacá is also used to make paper. Some of this is coarse, and some is so fine that it is the only paper which can be

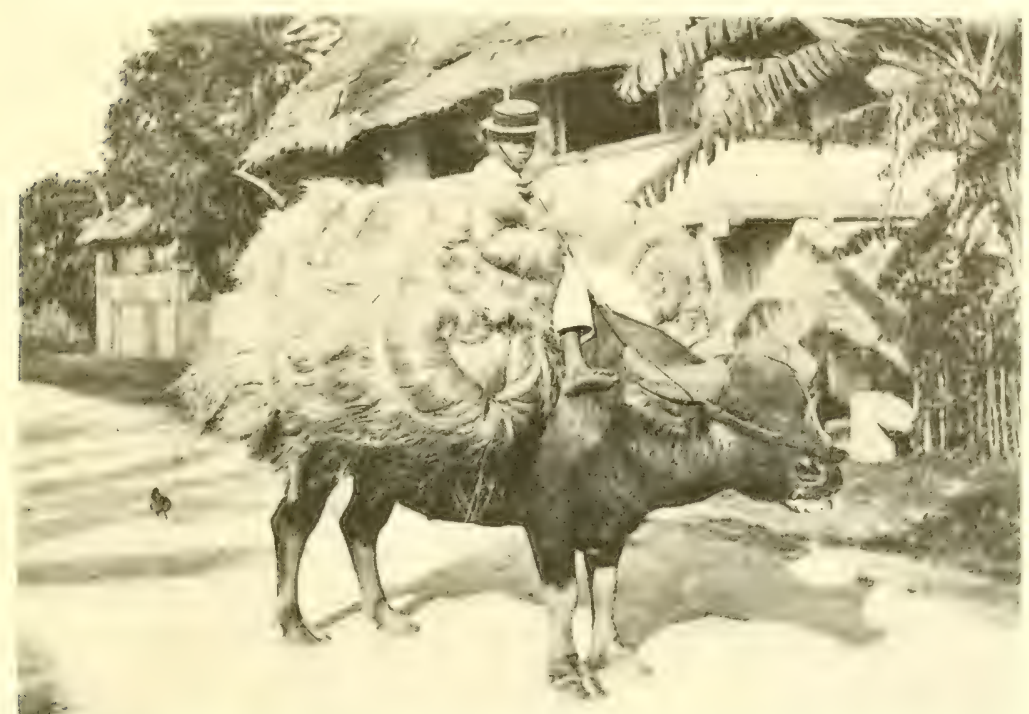

FIG. 95. Jaking abací fiber to market

used like silk, to wind the wires of induction coils. All paper made from abacá is very strong. In America and Europe, old, worn-out ropes made of abacá fiber are bought and used to make paper.

Production and Export. Abacá is a monopoly of the Philippine Islands. It is native here, and all of it has always been grown here. Ittempts have been made to introduce it inter Borneo, India, and elsewhere, but in these places it has been found too expensive to cultivate, 
or the product has been of poor quality. Some abacá has been exported from the Philippines for nearly a century. The following figures show the amounts (in tons) exported in the years indicated:

$$
\begin{aligned}
& \text { ISIS . 4I } \\
& \text { I\$2 . . 276 } \\
& \mathrm{I}_{4} \mathrm{O} \cdot \$, 5 \mathrm{O} 2 \\
& \text { I } 850 \text {. } 8,56 \text { I } \\
& \text { I } 860 \cdot 30,388
\end{aligned}
$$

$$
\begin{aligned}
& \text { I } 870 \cdot 31,426 \\
& \text { ISSO . 50,482 } \\
& \text { IS9O • 67,864 } \\
& \text { I } 900 \text {. } 89,43^{S} \\
& \text { I } 906 \text {. I 10,399 }
\end{aligned}
$$

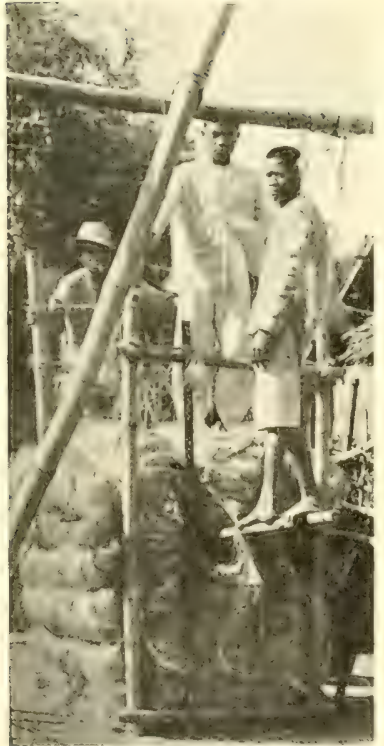

Fik 96. Primitive abacá press in Albay

Since I8S7 abacá has been the most valuable export every year except I 892 and IS93, when sugar held first place. Abacá is now more valuable than all other exports combined, being worth nearly fifty million pesos a year. The Census of I 903 shows the following to be the principal abacá-producing provinces, beginning with the most important: Leyte, Albay, Camarines, Samar, Misamis, Surigao, and Tayabas. Ladronism has since deprived Leyte of first place. Mindanao and Negros are rapidly increasing their production.

Conditions of Growth. Abacá is a plant with enormous leaves, and roots which do not reach deeply into the ground. There 
fore, if the soil, or even the air, is dry, and the plant is exposed to strong light or wind, it transpires too rapidly, and wilts. Constant moisture of both soil and air is absolutely necessary to its successful production. Take the maps which show the rainfall in the Philippines, and you will see that the great abacá provinces have a rather heavy rainfall, and no dry season.

Shade. Where there is a moderately dry seasom, abacá can be protected against it by planting it in sheltered places, as in valleys and ravines, and by the use of shade trees. These make cultivation difficult, and deprive the plant of light. Where there is moisture enough at all times, abacá can be grown on plains without shade; and then it will naturally grow more rapidly and produce more fiber than shaded plants can ever do. In Albay, I2 piculs of fiber is regarded as the greatest production of a thousand shaded plants in a year; but in Davao, a crop of 16 and even is piculs is produced as the average from each thousand plants on whole plantations of trees grown without shade.

Temperature. In the abacia provines the temperature is rather high and very uniform. An average temperature below $22^{\circ}$ would probably not permit its thrifty growth. It is cultivated at altitudes as great as I000 meters; but it is much more productive near sea level, unless the climate is too dry there.

Soil. Like other crops, abacá pays for rich soil by large crops. The soil must be moist. But it must also be well drained, for abacá roots die quickly if the soil 
becomes so full of water that they cannot breathe. The plants require much potassium; therefore, ashes are a

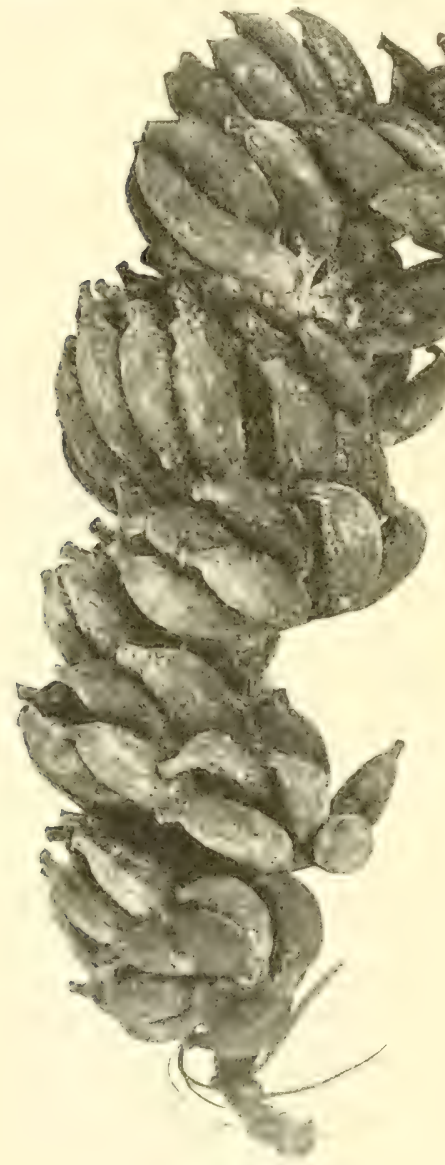

FIG. 97. Bunch of abacá fruit good fertilizer. It is probable that abacá wants a soil rich in lime.

Reproduction from Suckers. Abacá is reproduced chiefly by transplanting the young suckers which spring up around every plant. Old butts, from which the trunks have just been cut, can also be transplanted.

Reproduction from seed. Abacá can also be reproduced by seed. It requires a year longer for plants grown from seed to reach maturity; but in some places suckers are hard to get. If seeds are used, they must be from fruit which has not become overripe. The seeds should be washed well, soaked for several hours, and planted $2 \mathrm{~cm}$ deep and $15 \mathrm{~cm}$ apart, in rich, fine, shaded ground. In less than a year they are ready to be transplanted. Care should be 
taken to get suckers or seeds from the best available abacá.

Varieties. In every community there are several varieties in cultivation. The names of these varieties are mostly local. The varicties vary greatly in size, productiveness, case of stripping, and in color, fincenesis, and strength of fiber.

Shade Trees. Where shade trees must be used, those should be selected which will either preduce something of value or which will improve the soil. Ilangilang, pili, and the various fruit trees are useful for their products. The legumes are the best to improve the soil. The treés must not
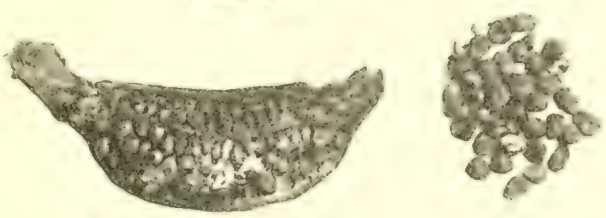

FIG. 98. Abacá fruit showing seeds only furnish shade, but they must also be strong enough not to break in the wind. Narra and ipil are leguminous trees which produce valuable wood and are not easily broken by wind. Other strong legumes used in this way are madrecacao and tamarind. The dapdap has the best effect on the soil, because its wood decays quickly. Both the madrecacao and the common spiny dapdap lose their leaves in the driest season, when the abacá most needs shade. There is a spincless form of dapdap which retains its leaves at all times, but it is less strong. It usually makes no seed, 
and is reproduced by sticking branches into the ground.

Cultivation. Where it can be done, the ground in which abacá is to be planted should be well plowed and cultivated. On ground which has just been cleared, this is impossible, but the ground around each plant must be

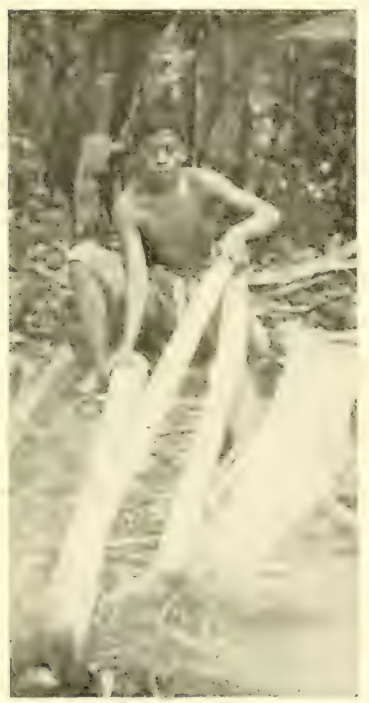

FIG. 99. Removing the outer strips from the leaf stems made fine. The plants of the large kinds must, of course, be planted farther apart than those of the small ones. The plants of a variety growing to a moderate size should be at least 2 meters apart on open ground. They should always be in straight rows, so that they can be cultivated easily.

IVe have already learned, in the chapter on Plants and Water (see page 42), how cultivation helps abacá to endure drought. It also makes it grow rapidly and mature early. From twenty to thirty months is usually the time between planting suckers and maturity. But well-cultivated abacá, the suckers being of only the usual size, has produced a large crop that matured in sixteen monthis. Abacá is mature when clusters of flowers appear, and must be cut before the fruit begins to ripen.

Harvesting. When it is mature, the abacá stalk is cut just above the ground with a sharp bolo, making a cut 
surface which is shoping, not horizontal, in oreler that water shall not stand on it. The leaves are then cut off the stalk. The individual leaf bases are peeded off, one at a time, and the outer part of each is remored in strips. It is these strips from which the filer is cstracted, while the softer inner part of each leaf base is thrown away. It is not desirable, even if possible, to strip the whole leaf base, the inside with the outside, because the weaker fiber of the inner part will make the whole product weaker than it ought to be. All of the parts thrown away in cutting the trunk and stripping the fiber are valuable as fertilizers.

Stripping. Stripping is almost always done

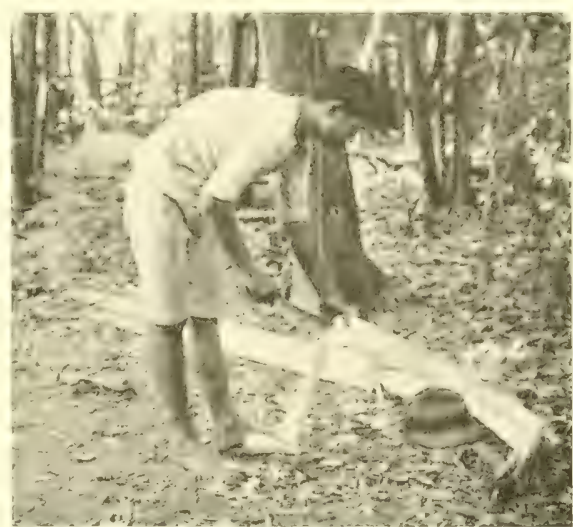

FIG. Ioo. Splitting abacá, before stripping by pulling the strip between a fixed block and a knife pressed against it by a spring. There are now several machines which will strip abacá; and except on small ficlds, stripping by hand will som coasc. It probalsly makes no difference whether the knives used are made of wood, copper, or iron, so long as they have perfectly smooth edgess. With a rough edge, aloacá can be strippeed more easily, and the product is hearier; but such fiber is not clean, and it will not bring a high price. 'The arle of 
a great deal of clirty abacá hurts the reputation and price of all abacá.

Drying. After it is stripped, the fiber should be dried in the sum, as quickly as possible. The whitest fiber is made by the cleanest stripping and quickest drying.

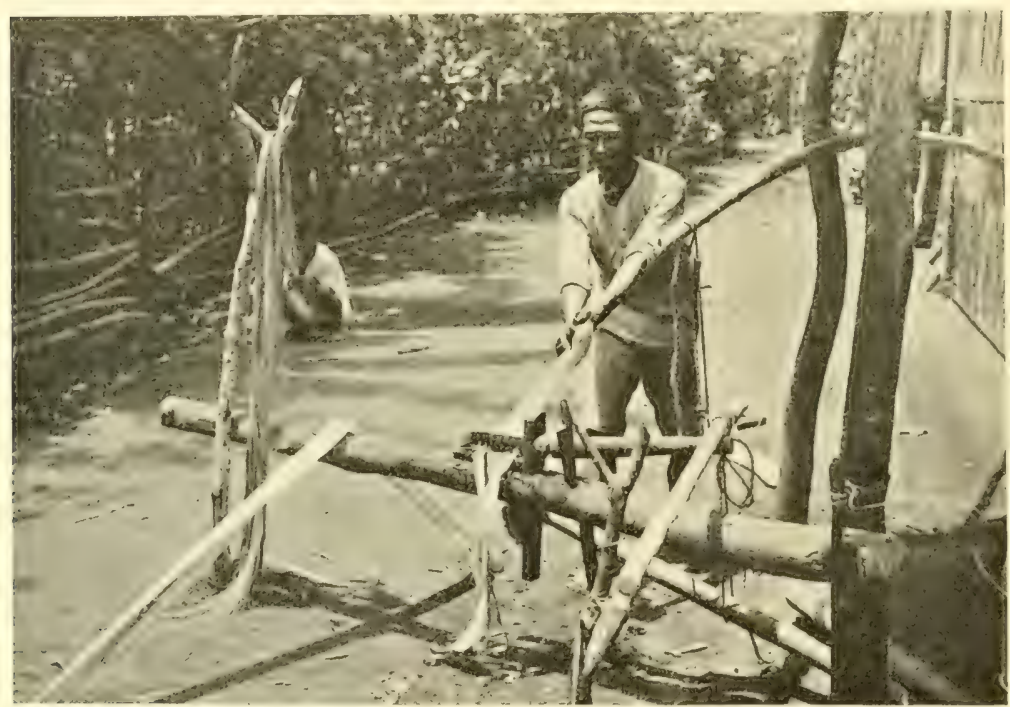

HIG. ror. Stripping abacá in Albay

The characters of good abacá are: first, strength; second, cleanness and lightness; third, whiteness; fourth, uniformity in length; fifth, length. Fiber almost six meters long has been stripped in Mindanao.

Use of Waste. The waste from stripping contains a great deal of fiber which is valuable for paper making. If much abacá is stripped in one place, it will be more conrenient to get the waste together to sell; but more 
of the plant's food will be returned to the soil, and so the latter will be kept richer, if the abaca is stripped and the waste scattered in the field.

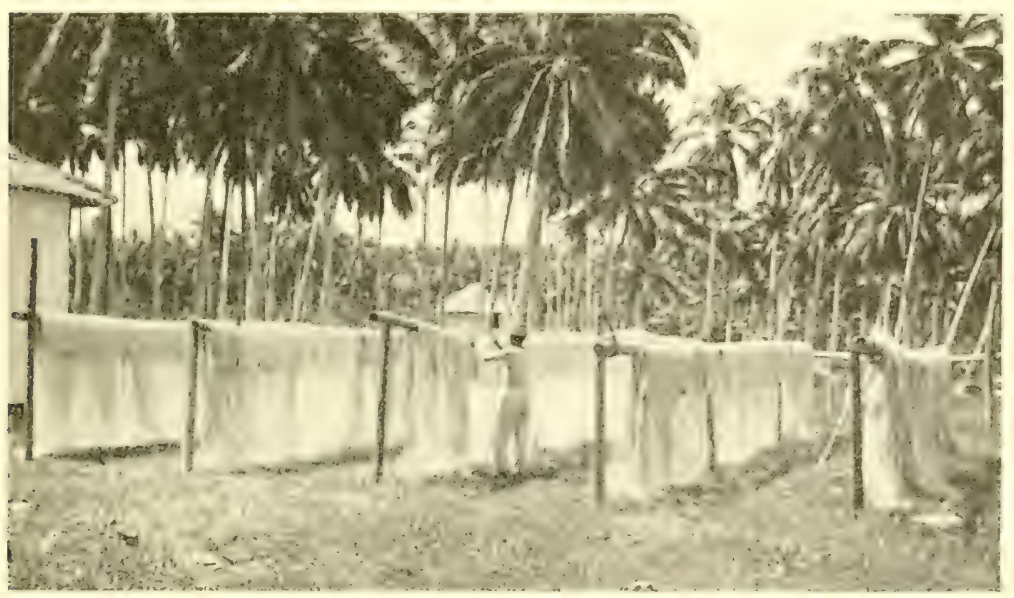

Fis. I02. Drying abacá fiber at San Kamon, Mindanao

New shoots of abacá are constantly becoming mature in a field. It is usually found convenient to cut each part of a field about four times a year.

\section{MIAGUEY}

Crops for Arid Lands. Almost all tropical plants require rich, moist land, and thrive only with fairly damp air. For this reason dry ground is regarded as poor, and a dry climate as unfitted to agriculture. Since dry land is poor and consequently cheap, it is especially important to know how it can be used. There are two Philiprine crops which endure dry soil and air; these 
are maguey and piña. Both are raised here for their fiber, and produce the strongest fiber where the air and soil are not too moist. Both also have other uses.

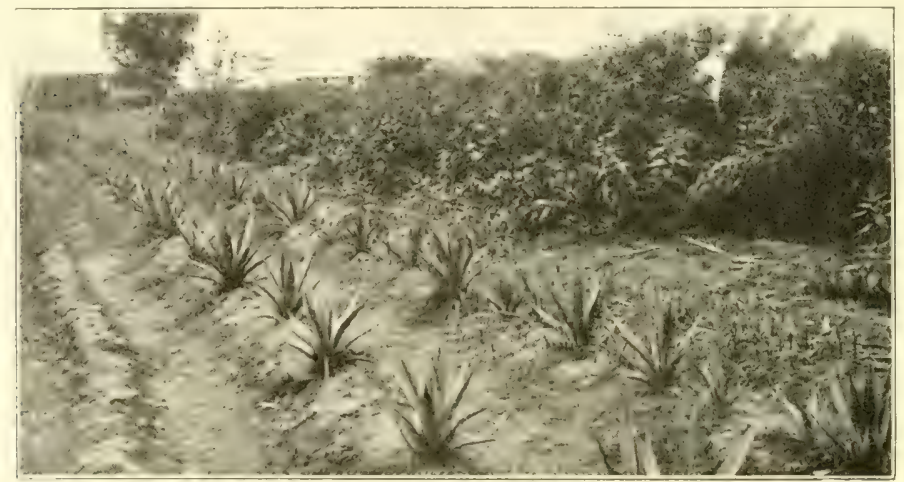

FIG. 103. Maguey plants

Kinds of Agave. "The plant called maguey in the Philippines is Asa'c intula. There are many species of Agave. Mll are natives of Mexico and Central America, but they now grow in all tropical countries. Most of the agave filere is produced in Yucatan, from the specics

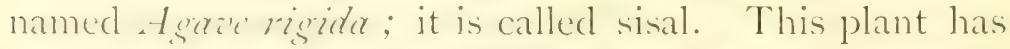
been introduced into the Philippines by the Bureau of Agriculture. The plant called maguey in Mexico is Asa'e amaricama, which produces a very poor fiber, but is grown to obtain a drink called pulque. Trhen pulque is distilled, it makes mescal. The maguey of the Philippines is cultivated in India also; but the Philippine fiber is better than the Indian.

Planting and Cultivation. Maguey is usually propa- 
gated by suckers, but sometimes by bulbils, which are branch buds formed in the axils. Thene maty be planted directly into the field, or kept for a year in seed beds. In the field the bultils are usually planted a little more than one meter apart in each direction; but it would be better to double this distance in places sheltered from the wind.

When they are planted, and for the following two or three months, the soil should be well cultivated and moist. After this, the hard, spiny leaves make cultivation impossilsle, and the plants are very little injured by drought. They will not grow in soil where the water stands near the surface. Dry air slightly retards the growth, but it slightly increases the fiber. I great deal of sunshine is especially beneficial.

Yield. In the Philippines a maguey plant yields hardly twenty leaves a year, each weighing 400 grams, of which 3 per cent to 4 per cent is fiber. The Yucatan sisal yields more leaves, each weighing one kilogram, and richer in fiber.

The fiber is extracted by stripping or by retting. Unless machines are used, the former is hard work. Excellent machines for cleaning sisal fiber have long been in use in Yucatan. Retting consists in soaking the leaves until the softer parts can easily be removed. If soaked too long, the fiber is valueless. I rying must be as quick as possible.

Describe the maguey plant fully and carefully. How old is maguey when it blossoms? How often does a plant blossom? How old is 
maguey before the first crop is produced? What provinces produce much maguey? Do these provinces produce much abacá ? Why ? How many poumls of fiber will a hektar of maguey proluce if the plants are I meter apart? Where is Yucatan ?

\section{PINEAPPLE}

The pineapple is a native of tropical America, but it is now found both cultivated and uncultivated in all tropical countries. Its botanical name is Ananassa sa.

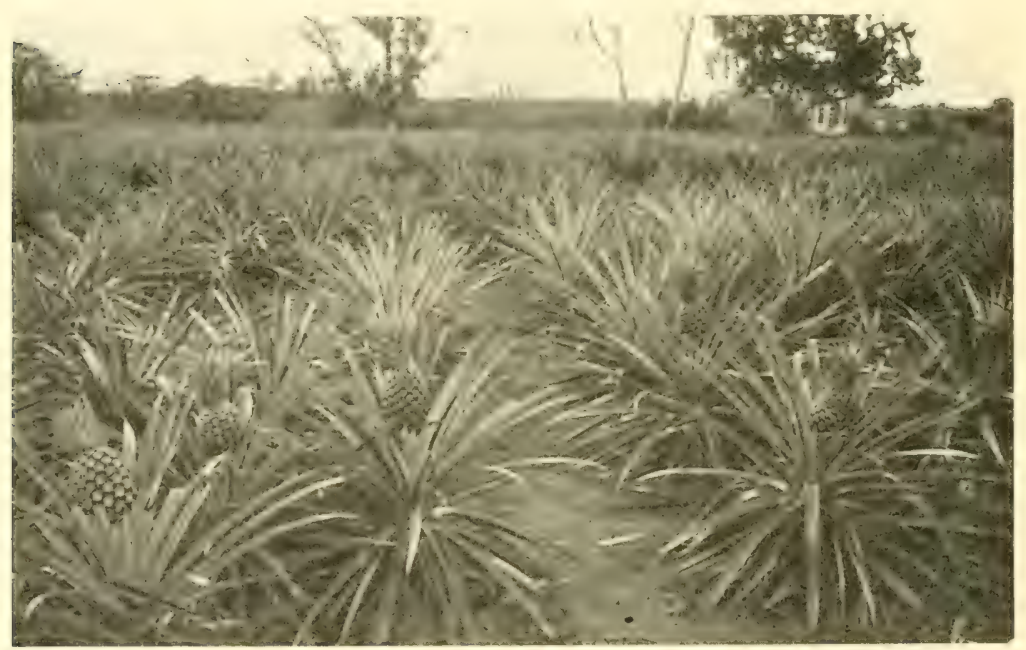

FIG. Iot. Pineapple plants in fruit

tiva. In most places it is raised for its fruit, and the fiber is relatively unimportant. There are fully one hundred varieties in cultivation, the fruit varying in weight when well grown from I to i 5 kilos, and in color being purplish, scarlet, dark red, yellow, green, and white. 
Propagation. L'incapples are propagated in four was:

I. By seed, taking from ro to 2 years before maturity.

2. By the fruit apex, taking from 2 to 5 years before maturity.

3. By stem shoots, taking from I 2 to is months before maturity.

4. By "root" suckers, taking from 8 to 12 months before maturity.

Besides being slow, propagation by seed is uncertain, and some of the finest varieties are seedless. Nine to twenty shoots or suckers are formed by each mature plant, on the stem above and below the ground. All suckers which come from the stems below the surface of the ground are called "root" suckers.

Planting. The young plants should be set out in the field in regular rows. They may be I meter apart in each direction; or, for convenience of cultivation, the rows may be $\mathrm{I} 20 \mathrm{~cm}$ apart, and the plants $80 \mathrm{~cm}$ apart in each row.

Pineapples for Fruit. When pincapples are raised for fruit, the soil must be deep, rich, and well cultivated, and never exceedingly dry. Fiy good cultivation while they are young, pineapples which would not weigh more than 2 kilos if uncultivated, can be made to grow to ro kilos. While the fruit is maturing, dry air and bright sunshine are necessary to produce the finest odor and flavor. Dust is very injurious; therefore, they must not be cultivated except while young. Buds and suckers should not be allowed to form before the fruit ripens. 
Pineapples for Fiber. Pineapples can well be grown for fiber on poorer and drier ground, and cultivation is then less necessary. In no case will this plant grow in ground where water stands. The soil must be rich in lime; and the plant is not injured by much clay.

Describe a pineapple plant, and draw it. What parts of the plant make up the fruit? For what purposes is the fiber used?

\section{OTHER FIBER PLANTS}

Cotton. The most important of the fibers in the world is cotton. Little cotton is raised in the Philippines, except in Ilocos Norte, Ilocos Sur, and L'nion. The cotton genus is Gosspizm, and at least four species are

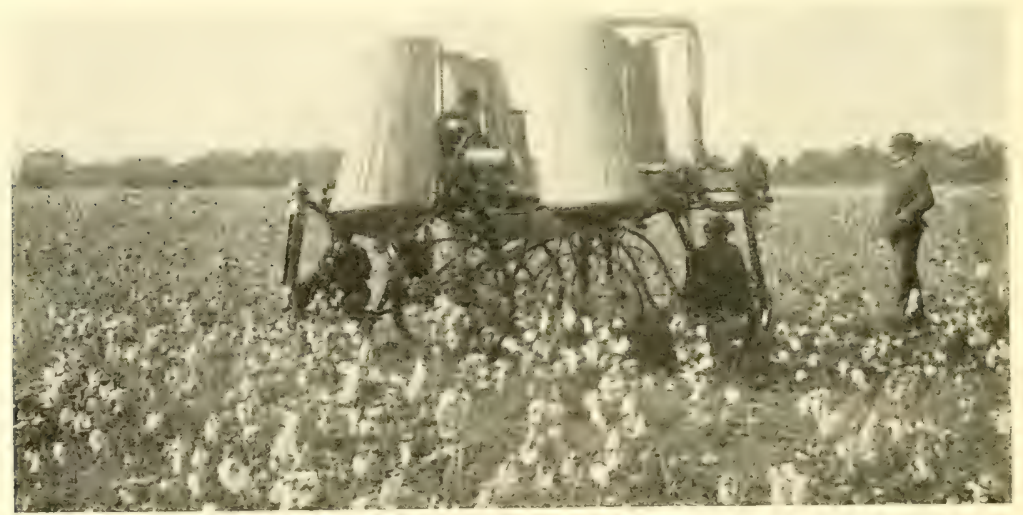

FIG. I05. Cotton field in the United States, showing cotton-picking machine

sources of valuable fiber; these species have become very mixed through cultivation. All of them were probably naturally perennial. The most valuable cottons are 
Sea Island and Eeyptian, but they are not the most productive kinds.

Cultivation and Uses. Cotton will grow well in most soils which are not exceedingly wet or shallow. Much lime improves the soil. The commonest cotton is a small bush. Its seed are sown in rows a meter apart. Many seeds are planted, and the young plants are afterward thinned out to about $80 \mathrm{~cm}$ apart. Fine weather is necensary for the ripening and harresting of the crops. The seeds are valuable for the oil they contain. The fibers are hairs on the seed.

Of what use to plants are the hairs of the seed? In what forms is cotton imported into the Philippines?

Kapok. The kapok, or silk-cotton tree, is a large tree, common in towns in the Philippines. Its fiber, like that of cotton, consists of tufts of hair ; these are not borne on the seed, but the seed is embedded in them. Its fiber is too curly to be used in making cloth; but it is excellent for stuffing pillows, and for similar uses.

Jute, Rattan, etc. There are many other Philippine plants whose fibers have some value. Among these are jute, a weed in many of the towns; ramie, a wild bush ; bow-string hemp, which is often planted for ornament along strects and walks; and the various kinds of rattin, or bejuco. The fiber of the coconut husk is spoken of in another chapter. Good paper can be made of cogon, bamboo, and many other Philippine plants. 


\section{CHAPTER XVI}

\section{TOBACCO}

History. Tobaceo is the plant known botanically as Nicotiana Tabacum. It belongs, with the tomato and eggplant, in the potato family. It is a native of America, and probably of the warmer parts of that continent, but was found in cultivation as far north as Virginia by the European discoverers. There are about fifty other species of Nicotiana. Of these, only one, that which produces the Syrian tobacco, has any agricultural importance.

The Tobacco Plant. The comm in tobacers has a glandular stem I to 2 meters in height, which becomes woody as the plant matures. The stem branches freely from the axils; and as it matures it sends up fresh branches from the base. The prompt removal of all branches, as they start to grow, not only strengthens the leaves and hastens their maturity, but is said to make them lighter in color.

The stem bears from eight to twenty leaves on very short petioles. The larger leaves are 35 to $50 \mathrm{~cm}$ long, and 7 to $15 \mathrm{~cm}$ broad. On the leaves are two kinds of glandular hairs-long ones, made of several cells, and others only one cell long. Many kinds of leaves are 
used to adulterate tolnaceo, but not one of these has the two kinds of hairs.

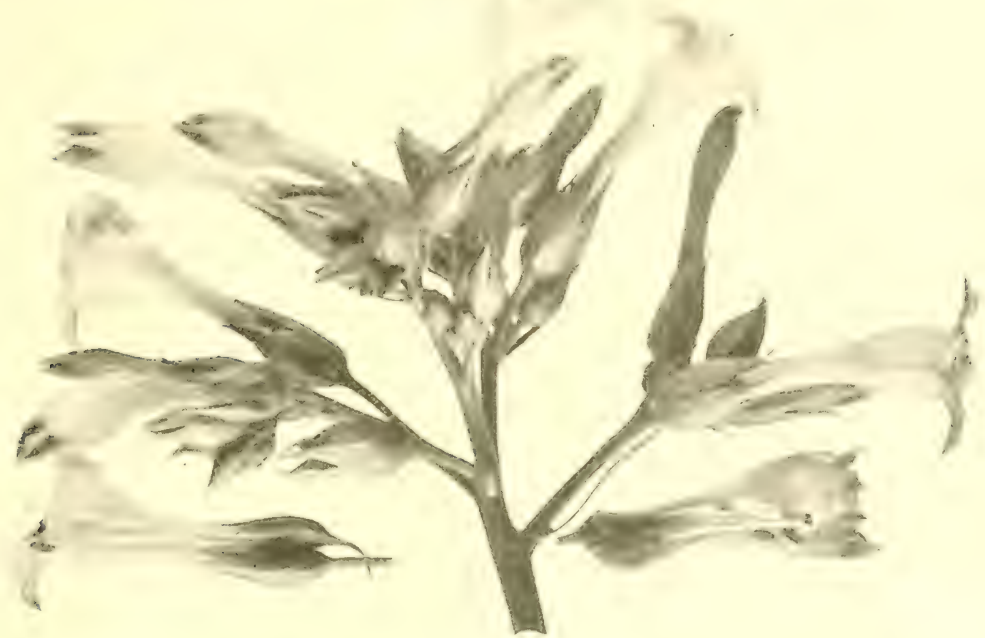

Fis: Io6. Flower of the tobacco plant

The flowers are borne in a loose cluster at the top of the stem. Flowering lasts about two weeks. The fruit is a small, pointed capsule, containing a great many very small seeds.

Nicotine. The plant contains several peculiar sub. stances, among which is a poison named nicotine. It: is this substance which produces the physiological effects of tobacco. As a general rule, the varieties of tobacco with the most and finest aroma contain the least nicotine. Therefore, the most valuable tobaccos are usually the least injurious. However, there are many exceptions to this rule. 
Taxation on Tobacco. Aside from a very limited medicinal use, tobacco is altogether a luxury. It is the most important crop in the world which is not valuable as food or clothing. It is chewed and snuffed, and smoked in pipes, cigarettes, and cigars.

Because it is an article of luxury, tobacco is usually handled at a large profit. Most countries tax it very heavily, and some make it a government monopoly. It was a monopoly in the Philippines from i $7 S_{1}$ to ISS2, the whole tobaceo business belonging to the gorernment during this time. In IS82, the profit on this business paid half of all the expenses of the government. In the United States the government taxes the tobacco business in several ways; the internal revenue tax on it amounts to more than one hundred million pesos a year.

\section{PRODUCTION}

Production in the World. The foremost country in the production of tobacco is the United States, the yearly crop there being more than two hundred thousand tons. All of Europe produces hardly so much; Russia and Hungary produce more than the other European countries. India produces almost as much tobacco as the United Stater. Turkey raises over thirty thousand tons, the Dutch East Indies about as much, and Japan nearly twenty-five thousand tons. Cuba, the Philippines, and Brazil are the other important countries.

Production in the Philippines. The export of tolacco from the Philippines at different times has been, in tons: 


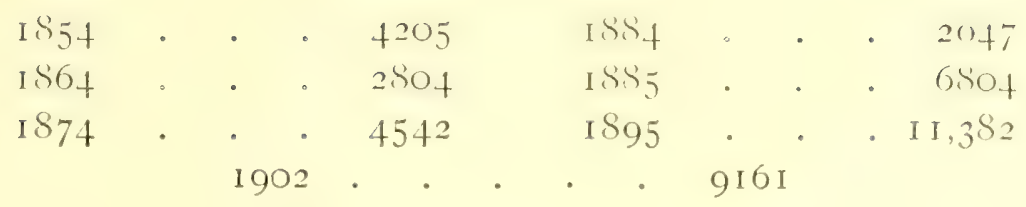

The export of 1874 was the most valuable of these, being worth 6,95t,000 pesos. Philippine tobacco is very largely made into cigars and cigarettes.

The foremost tobacco-raising province, both in quantity and quality, is Isabela. In the amount produced, it is follomed by Union, Cagayan, Cebu, Pangasinan, and Ilocos Norte. The raising of tobacco was prohibited in some parts of the Islands by the Sipanish government. This furnished a local market, and made it easicr to keep up the grade of the tobacco.

\section{CONDITIONS OF GROWTH}

Heat. Tobacco is like the potate and maize in being a tropical plant which will grow in a large part of the temperate zones. 'This is not because the plant endures low temperatures, for frost is fatal to it, but because it can grow and mature its fruit in the few months of the Northern summer. Coffee cndures a lower temperature than any of these plants, but can be cultivated only in the tropics. Tobacco grows as far north as Minnesota, and even in Canada and in Sweden.

Moisture. A fine quality of tobacco cannot be produced where the air is very dry. On the other hand, there must be no very heavy rain while the leaves are maturing, or while they are being dried. Heavy rain 
sometimes tears the leaves or makes them rot, and always gives them a coarse texture with prominent ribs. Too dry air causes the pores of the leaves to become permanently shut, and it is then impossible to cure the tobacco well.

The parts of the Philippines with a dry season which is moderately dry, and during which there may be showers but no long rains, have an excellent climate for tobacco. The air is rarely dry enough to be injurious, and never is so if the fields are irrigated. Except so close to the shore that the winds are salt, sea air is very favorable to tobacco. In islands no larger than the Philippines the air in most places carries the moisture from the sea.

Soil. There is no other Philippine crop) whose quality depends so much on the soil as tobacco. Its soil must never be a very heavy clay; and, unless well drained, it must be rather light. The color of the leaves depends largely on the color of the soil; so that on light-colored, sandy soils light tobacco is raised, and dark tobacco grows on dark loam or mold soils.

Tobacco leaves contain more ash than is found in any other of our crops. Therefore they make poor the ground where they grow more rapidly than any other crop does. I.ike all plantes, tobacco must have lime and nitrogen, but a soil very rich in either of these is bad for it. Lime keeps the leaves from burning well, and much nitrogen makes the leaves too rich in nicotine. A good sugar soil is the worst soil for tobacco. Potash has the 
(1)posite effect to lime, and must therefore be abundant in the best tobacco soils. Iron causes the red color of "colorado" tobacco, and it is usually desired that tobacco soils contain much of it. The soil in many places in the Philippines is very rich in iron.

\section{CULTURE}

Selection of Seed. Pone tobacco can be raised without work anywhere in the Philippines, but it cannot be sold. There is no other crop whose value is so dependent on the quality. The tobaceo good enough to be exported from Cuba and Sumatra ranges in price from i 5 centaros to 7 pesos a kilo.

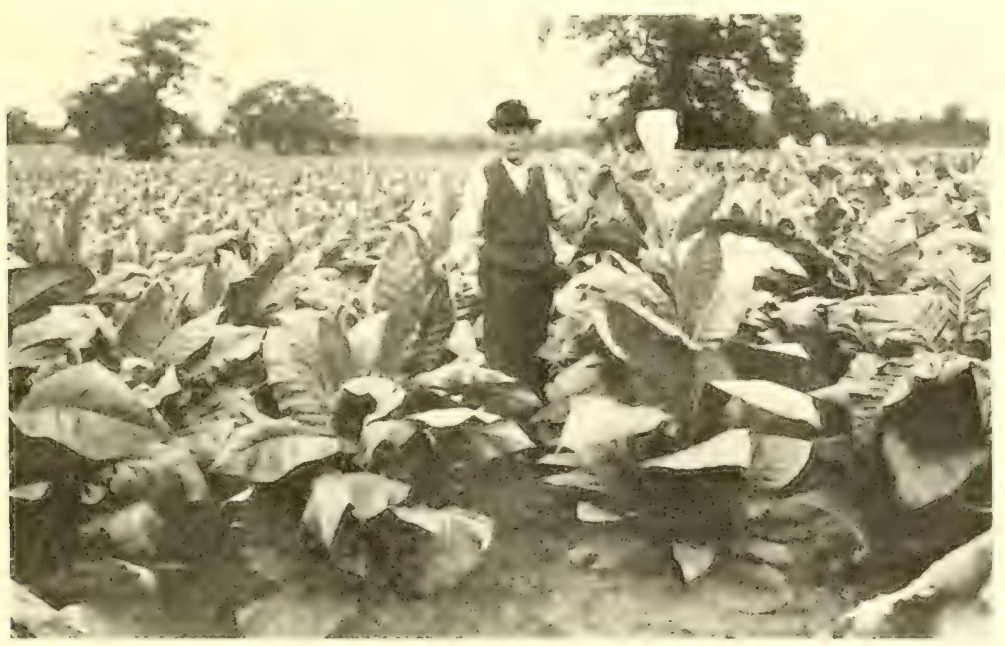

FIG. I07. A well-cuitivated tobacco field in the United States

The first step toward raising fune tobaces is getting the seed of fine tobaceo. No other single thing has 
done so much to give Sumatra tobacco its excellent reputation as the care of the Dutch government that no poor seed shall be planted. The Spanish government did the same work here during the tobacco monopoly, and the deterioration of Philippine tobacco since that time has been largely due to the use of much unselected seed. Sumatra tobacco came originally from Havana seed; and many planters in the United States, in South America, and cren in Russia, now get their seed from Cuba every year. The highest-priced tobaccos are now raised in Cuba, Sumatra, and Turkey.

Seed Beds. Tobaceo seed is usually planted in seed beds. In the Philippines the seeds are likely to be stolen by ants, and where this is the case, it is best to plant it in boxes which ants cannot reach. Some planters use a large quantity of seed in seed beds on the ground, and trust that the ants will leave some of it; but seed so poor that it can be fed to ants ought not to be planted.

In the seed bed the soil should be very light and exceedingly fine. Ishes and horse manure are good fertilizers for the seed bed. The seeds must be planted shallowly, because they are very small. If they are sown broadcast, a teasponful is enough for 20 square meters of bed. The seeds will be more uniformly scattered if they are thoroughly mixed with 5 teaspoonfuls of fine ashes, before they are sown.

A better method than broadcasting the seed is planting them with a hand drill. If they are drilled in, they should be in rows ro $\mathrm{cm}$ apart, and placed $4 \mathrm{~cm}$ apart 
in the rows. The bed can be covered lightly with coarse grass until the first leaves appear, and ought not to need watering. After heary rain, the grass must be renewed.

Transplanting. Tobacco should be transplanted when it has four or five leaves the size of a pesos. The ground prepared for the plants must have been very thoroughly cultivated. The easiest way is to plant them on level. flat ground; but it is usually better to raise each plant, putting it in a little hill, or to plant them in rows along low ridges. If the hills or rows are too hight, the ground will be likely to become too dry. A proper distance between plants is $75 \mathrm{~cm}$ in each direction. They will produce larger leaves if planted $90 \mathrm{~cm}$ apart, but the leaves will be coarser in texture and less mild.

If some plants are injured in transplanting, they should be replaced at once, even if they are not dead, for injured plants grow slowly, and the crop should be matured as rapidly as possible. The longer the crop) is in growing, the more likely it is to be destroyed, by storms or otherwise. The finest leaves are those which grow most rapidly. It is well worth the extra work to transplant a block of earth with each plant so as to disturb the roots as little as posibible. The plants must be set into the ground just as deeply after transplanting as they were in the seed bed.

Cultivation. As soon after transplanting as the roots are well fixed in the new ground, which should be in not longer than one week, the ground should be well forsened with a cultivator or hoes. If this first cultivation 
is clelayed, it will be bad for the growth of the crop. For four weeks after this, the ground should be cultivated each week.

Removal of Tops and Leaves. At about the time when the first blossoms open, or a little later than this, the top of the plant should be removed, as well as the lowest leaves, which are usually unsound or dirty. The number of leares that should be left on the plant depends on its size and strength, and on how high a price can be (o)tained for finer leares. Ten is a good number to leave, and twelve should be the maximum.

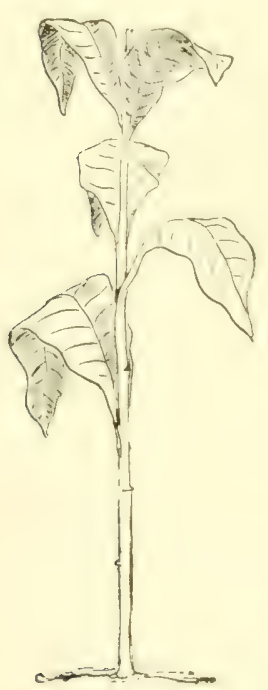

Fri. IOS. Toldew inlant after top and lowest leaves are removed

If some of the finest plants are to furnish seed, the tops of these, of course, must not be removed. From the time when the tops are cut, the branches begin to grow, and must be nipped as they appear, before they bear any flowers.

Harvesting. Tobacco should be ready to harvest about ten weeks after it is transplanted. Before it is ready the leaves wilt and hang down, their green color fades, and they become spotted with brown or yellow; they lose their fresh texture and begin to crumple, and suckers begin to grow from the base of the plant. The plant should then be cut off and hung in a well-ventilated building. 
With the best and the most perfect cultivation, good tobacco can be produced only by proper curing of the crop. But the curing is too complicated a process, and too dependent on local conditions and also on the way in which the tobacco is to be used, to be described here.

Describe the insects attacking tobacco where you live. How are these insects fought?

How is tobacco cured in your town?

Where is Havana? 


\section{CHAPTER XVII}

\section{COFFEE}

Species. Almost all of the coffee of the world is the product of one species of tree, Coffea arabica. A small

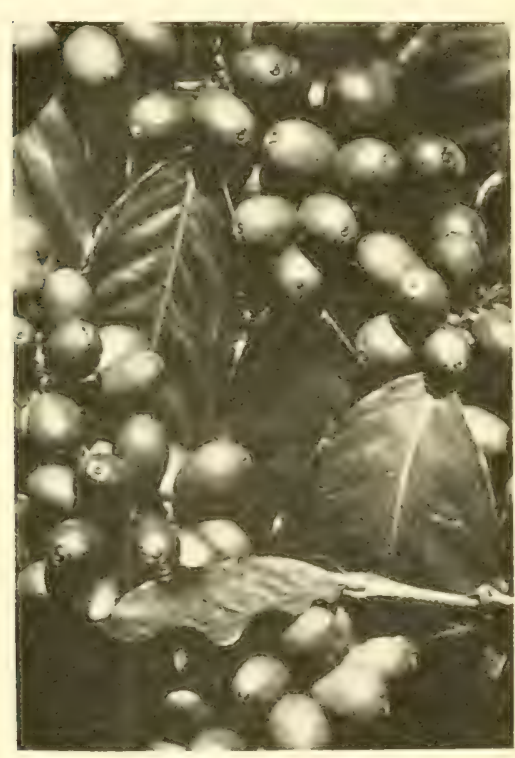

FIG. Iog. Coffee fruit amount is also produced by Coffea liberica and by hybrids between the two species.

Coffea arabica is a small tree, rarely more than 5 meters high, with opposite, simple, entire, smooth and shining, evergreen leaves, 8 to $\mathrm{I} 2 \mathrm{~cm}$ long. The flowers are borne in axillary clusters.

Coffea liberica is a larger tree, with leaves 20 to $30 \mathrm{~cm}$ long, and larger fruit than Arabian coffee. It has an inferior flavor, and has come into cultivation only since the coffee rust made the culture of Coffec arabica a risky business in Ceylon and Java. 
Ceffice rrabice is a native of the mountains of eastern Africal, from Abysinia to Mozambique; it has also been found wild in Angola. It is called Arabian coffee becaluse it was furst introduced to the rest of the world by the Arabs, and was first cultivated as an article of commerce with Europe, in Arabia.

\section{PRODUCTION}

Total Exports. Figures on the amount of coffec produced are not very accurate, because we do not know how much is comsumed in the countries which produce it, but only how much they export to Europe and the United States. However, it is easy to see how rapidly the industry has grown. The number of tons exported from the cotintries of the world has been:

$$
\begin{aligned}
& 1832 \text {. . . 96,000 IST5 . . 513,000 } \\
& \mathrm{IS}_{44} \text { • . . } 259,000 \quad \text { ISS I . . } 598,000 \\
& \text { I } 855 \text {. . . 326,000 IS9I . . } 558,000
\end{aligned}
$$

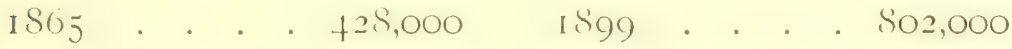

The amount is now more than a million tons. Of this Brazil produces one half, and the rest of America one fourth. The I )utch East Indies produce a large part of the coffee of the ()ld Mrorld, followed by India, Madagascar, II est Africa, Ceylon, Arabia, etc, and the Philippines.

The United States consumes about one half of the coffec, followed by Ciemany, France, Austria, Belgium, and England. 
Production in the Philippines. I few coffee plants seem to have been cultivated in the old Manila botanical garden more than a hundred years ago. In $S_{37}$ the Sociedad Económica awarded a prize of $\mathrm{s} 000$ pesos to a man who was supposed to have 60,000 bearing trees. Jagor, a German traveler who visited the Philippines in I 559 and I860, wrote: "The coffee plant thrives wonderfully, and its berry has so strongly marked a flavor that the worst Manila coffece commands as high a price as the best Java.'

The coffee exported from the Philippines is still of an cxceedingly fine quality. The amounts exported have been, in tons:

$$
\begin{aligned}
& \text { I } 856 \text {. . . . } 500 \\
& 187 \mathrm{I} \cdot \cdots \cdot 3500 \\
& \mathrm{I} 874 \text {. . . } 2 \mathrm{I} 5 \mathrm{O} \\
& \text { I } 879 \cdots+. \cdot 4195 \\
& \mathrm{ISS}_{3} \cdot . \cdots 4560 \\
& \mathrm{IS94} \cdot . . .603 \\
& \text { I } 895 \text {. . . . . ISo (from Manila only) }
\end{aligned}
$$

Important Coffee Districts. () the Christian provinces, Batangas has been foremost in coffee production; its chief center was Lipa. Second in importance was the highland part of Carite, near Indang. It the time of the great Philippine expert of coffee it was almost entirely fumished by these two provinces. It must be twenty-fire or thirty years since coffee was introduced into northern Luzon. The greatest production of this district was 
about 1 S9o, but the yield is now important and growing.

It is not known when coffee was introduced into the Moro country, but it was surely long ago. The Lanao district is probably the chief source of Moro coffee. Mindanao now exports more coffec than Luzon. In all parts of the Philippines some coffee is raised for local use, but none is exported except from the parts already named. Liberian coffee has been cultivated for several years near San José, Batangas, but as yet without much profit.

\section{CONDITIONS OF GROWTH}

Temperature. Coffee is a tropical plant; but since it is likewise a mountain plant, it does not need a high temperature, and does not thrive where it is very hot. The coffee plant is very healthy, although it does not grow very rapidly, where the temperature is uniform and averages lower than $20^{\circ}$ throughout the year. It even endures light frosts. Liberian coffee requires greater heat. It would perhaps thrive at sea level in the Philippines, and in places where Arabian coffee grows, Liberian should not be shaded.

Moisture. Coffec is maimally a fores plant, and requires a constantly moist air. This can be provided by shading the plants, where the climate is too dry or slightly too warm for them to endure the sunshine.

We know that the moistness of the climate increases with the altitude. The lowest good colfee country in the Philippines is the highlands of Batangats and Cavite, at 
an altitude of about 400 meters. The Moro coffee is raised mostly at above joo meters. In northern Luzon, the finest coffee is raised in Balili, Kabayan, Daklan, and Sagada at altitudes above 1500 meters. In these places it is so cool and moist that coffee requires no shade. Moreover, the low temperature is bad for the rust; so that it is possible to raise a crop of good coffee in these places as often as once in two years, even though the rust is not fought in any way whatever.

Coffee likes also still air; because wind, like heat and dryness, hastens the transpiration. The same trees which furnish shade break the wind. The trees used to shade coffee are the same ones used for abacá, usually dapdap and madrecacao.

Soil. Coffee demands a fairly rich, deep soil, for its taproot descends 2 or 3 meters. I'olcanic soil, whether formed from lava, or from showers of ashes, is excellent for coffee. After an eruption of 'Taal which covered the plantations of Cavite with ashes, the coffee bore such crops as never before. And twice within recent years there have been showers of volcanic ashes in Guatemala which seemed to destroy the near-by plantations; but each cruption was followed by an unusually heary coffee crop.

CULTURE

The Seed. Coffee is always reproduced by seed. The seed to be planted should always be picked from the best trees. It is very unwise to propagate coffee by transplanting the young trees found in the orchard, for 
these usually grow from seed which fell too carly, and so were lost in the picking. The trees which grow from these seed will probably also shed many seed as they ripen, and this is very undesirable.

The seed can be planted in bamboo tubes, or in seed beds. If seed beds are used, they should be of rich soil,

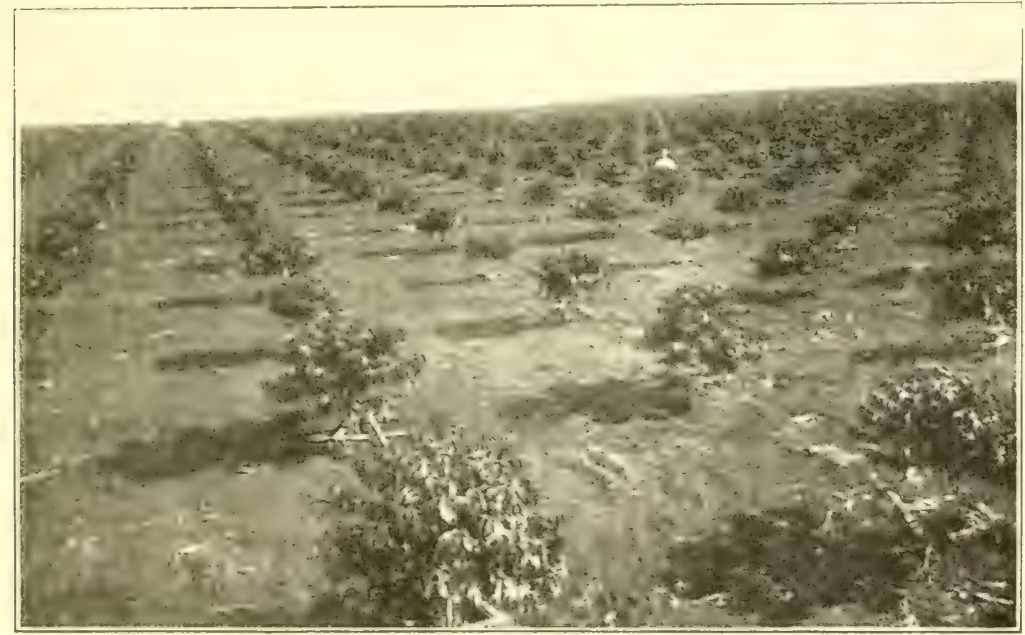

FIG, I1o. Coffee plantation in Brazil

made very fine and soft to a depth of at least $25 \mathrm{~cm}$. The seed may be planted $2 \mathrm{~cm}$ deep, and $15 \mathrm{~cm}$ apart in each direction. The seed bed must be kept moist, and this is usually impossible unless it is kept shaded. Coffee seed is very slow to germinate, sometimes taking more than two months. During this time and until the young trees are transplanted, the beds must be kept free of weeds. 
Transplanting. The trees are transplanted early in the rainy season, when they should be six months or more old. The taproot must not be broken or cut, for this is likely to injure the tree permanently. The trees might

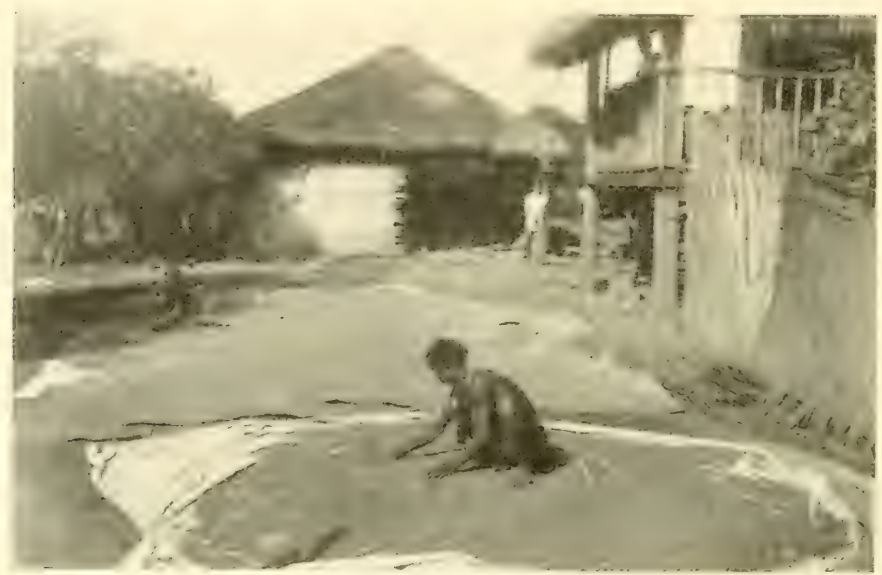

FIG. III. Drying coffee in Benguet

be left another year in the seed beds, if planted $25 \mathrm{~cm}$ apart; but it is more difficult to transplant these larger trees without injury. No trees which are weak or unsound in any respect should be transplanted.

Where trees are to be planted, it is a good practice to dig a hole $40 \mathrm{~cm}$ wide and deep, and to fill it around and under the tree with rich earth. Two meters in each direction is a good distance between trees. In Ceylon they are planted closer trigether than this, and kept trimmed very short; while in Brazil they are 3 or 4 meters apart, and·not trimmed at all. 
Care of the Trees. The Philippine coffece is undally. rather small; and it is advisable not to let it grow more than 2 meters in height. At that height it is easy to pick the fruit, and the trees can be sprayed to guard against the coffee rust, without a great waste of the Bordeaux mixture. As has already been explained in the chapter on plant diseases, a coffee plantation must be kept clean of dead leaves and branches, as a protection against rust and insects.

Coffee is likely to bear a good crop when four years old, and to bear every year for more than a decade. The methods of handling the crop are very different in elifferent countries. 


\section{CHAPTER XVIII}

\section{CACAO}

The Cacao Plant. Cacao is the name of a plant, Theo-

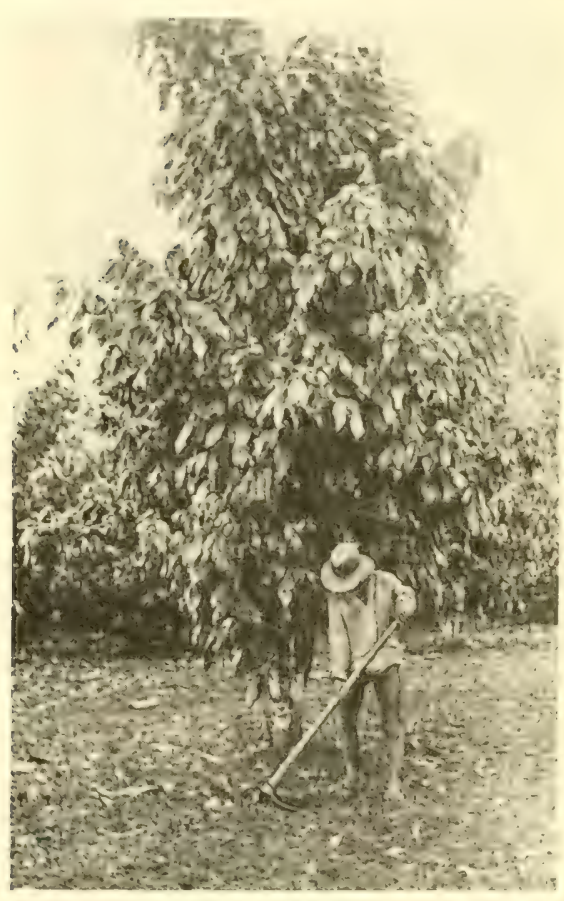

FIG. II2. Healthy young cacao tree in the Philippines broma Cacao, and of some of the products obtained from its seed. Chocolate, which also is yielded by these seed, contains more oil than does cacao. The tree is a native of tropical America. It must have been in cultivation fora long time before the Spanish dis covered America, for it was then found all the way from Mexico to southern Brazil. In the same region are more than twenty other trees in the same genus; the seed of some of these is sometimes collected and mixed with real cacao. 
Production. Some cacan is mom raised in all tropical countrixs. The foremost country in the amount produced is Ecuador, but Venezuela is foremost in quality. The Philippines and (eylon have been the chice sourecs of cacao in the Old World. The mountainous little island of Maripipi produced in Spanish times the finest cacas in the world, - so fine that it sold for a peso a liter, or almost twice the best market price of Venezucla cacao.

Uses. The chief use of cacao is in making drinks, cocoa or cacao, and chocolate; but a great deal is also used in candy and pastry, and as a solid food. Mountaineers

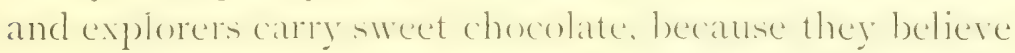
that it is the most convenient and valuable of all foods, in proportion to its weight and bulk.

Description. Cacan is a small trece uskally reaching a height of about 7 meters and a diameter of about $10 \mathrm{~cm}$. The flowers are clustered on dwarfed branches, on the trunk and leafless limbs. As a rule, only about one tenth of the flowers produce fruit. The average number of fruit on a tree is twenty or thirty, though some trees produce many more.

Describe a leaf of cacao. How does it differ from that of coffee?

Describe the flower, and illustrate all parts.

The fruit is Io to I $5 \mathrm{~cm}$ long, and half as thick, with ten lengthwise furous. In the I'hilippines it is usually red before it is ripe, and afterwards becomes brown. It usually contains as many as forty reddish or brownish seeds, each of which is composed almost entirely of the two fleshy cotyledons. 


\section{CONDITIONS OF GROWTH}

Climate. Ciacandemands more wamth and more moisture than does coffee. It will not produce large crops where the annual rainfall is much less than 2 meters, nor where there is a severe dry season. However, if the rain is too little, it can be made up in part by irrigation, with equally good results. The average yearly temperature must be at least 22, and may well be higher. Strong winds do great damage, both by increasing the transpiration, and by shaking off the fruit.

Soil. Since this tree has a taproot, it will not be very thrifty in soil less than I meter deep. It will endure standing water in or over the ground longer than most cultivated crops; but, like other crops, it is more healthy and productive on well-drained soil. It is sometimes possible to kill its insect enemies by drowning them.

A good soil for cacao must be reasonably rich in lime; one half of I per cent is necessary for a fair crop, and I $\frac{1}{2}$ pere cent is better. Much iron in the soil is an adrantage, because it darkens the seed, and dark seed brings a better price. Cacas exhausts the phosphores of the soil rather rapidly.

\section{CULTURE}

Planting. Cacao is reproduced by seed. These can be planted where the trees are wanted, or in seed beds. The disadrantage of using seed beds is that the plants grow rapidly, and do not stand transplanting well. Injury to the resets can be aroided by planting the seed in bamboo joints, and merely splitting these when the 
plants are large enough to be put in their permanent places. The disadvantages of planting the seed where the trees are wanted are that they must be cultivated and shaded while still very small, and that insects and other animals are likely to eat the seed. Insects can be kept away by putting ashes around the seed.

The seeds are planted 2 or $3 \mathrm{~cm}$ deep, and should germinate within two weeks. If seed beds are used, the plants should be $15 \mathrm{~cm}$ apart, in rows $25 \mathrm{~cm}$ apart. It is probably never advisable to have the trees less than 3.5 meters apart, though they are said to have been much closer together in Maripipi. The first crop is obtained when they are four or five years old.

Shade. Cacao must always be shaded. The same kinds of trees are used to shade cacao as to shade coffec. Since cacao grows at lesser altitudes, and endures a denser shade than coffee, it is more often practicalble to use shade trees which themselves yeld useful products. Bananas are used to shade young cacao, and ilangilang and some of the large fruit trees can be used when the trees are mature. Young plants of some large tree are planted in the place of about one twenticth of the cacao trees.

Cultivation. Whether ol not the ground is weedy, cacao will much more than pay, by the greater yield, for a cultivation of the soil twice a year. The trees should also be pruned once a year, and kept from becoming too high. The fruit should always be cut, not broken off, to save the place for future flowers. 
Enemies. (acao has many enemies, both insects and fungi. In the Philippines, a wood-boring insect, and another which destrogs the fruit, have becen very destruc-

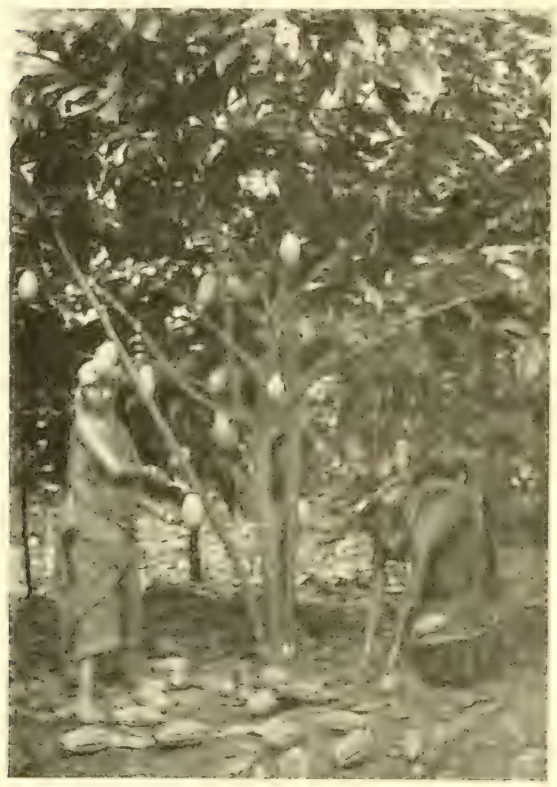

FIG. Ir3. Cacao tree in fruit in Venezuela tive, and during the last decade have made it impossible to raise cacao with profit in many places.

Crop. While a good crop should be obtained when the trees are five years old, it increases until the trees are twelve years old. For many years, then, the yield should be at least 500 kilos a year from each hektar. In Cebu, the foremost province in the Philippines in the production of cacao, the Census of I goz showed the average yield to be 390 kilos. A great advantage in the culture of cacao is the small amount of labor required. On this account it is about as profitable a crops as coffee, although the coffee crop from an equal area of ground is much more valuable. 


\section{CHAPTER XIX}

\section{FRUITS}

Tine word "fruit" has two uses. Botanically speaking, any structure which contains seed is a fruit. But in more common use the word is applied only to those which are fleshy and edible. This chapter is about fruits in this narrower, more common, sense.

The Philippines have more fruits than have most countries, and some of them are of excellent cuality. But others are not so good as in countries where they receive better care or where better varieties are cultivated.

\section{BANANAS}

History. By far the most improtant Philippine fruit is the banana. Almost or quite all of the Philippine cultivated bananas are forms produced in cultivation from a single species, Musa sapicntum, which is not positively known except in cultivation. There are many wild species of Musa in this part of the world, and some of these may have given rise to cultivated forms. The banana is a native of Malaya or southeastern Asia, but history does not tell when it was introduced into all other tropical countries.

Description. In its stem, flowers, and fruit, the banana is practically like the abacá, except that in all the finer 
varieties of banana the seeds are reduced to mere specks. In some varieties, however, as in the one called latandan in Manila, a few large seeds are sometimes found.

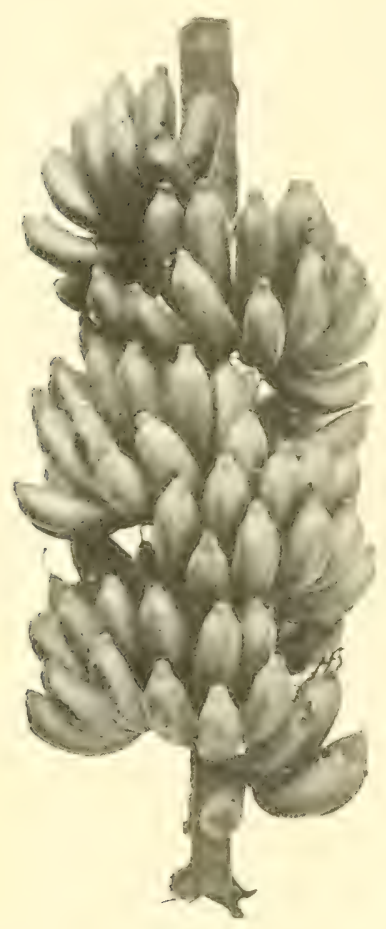

FIG. II4. Bunch of latandan bananas

Uses. The banana has various uses. The broad leaves are used for wrapping in place of paper; they are also used as dishes. The juice is used as an astringent and to fix dyes. After the fertile flowers have blossomed, the staminate flowers at the end of the cluster, with their bracts and fleshy stem, are cut off and cooked, and eaten as a fresh vegetable or as a salad.

Varieties. There are many varieties of bananas. A. M. Ellis, teacher in Leyte, has found more than sixty different ones in that island alone. They differ in the size and appearance of the plants, in the time which they take to mature, and in the size, shape, color, texture, flavor, and uses of fruit. They also differ in the conditions under which they will thrive. Many of them are very local, and others have different names in different places.

The favorite varieties for eating raw are the long green ones, spotted when ripe, called bongulan in Manila, and 
the lakatan, which is yellow. The morada is a very rich variety, brownish red in color, probably introduced from tropical America. In general, the finest varieties require the longest time before they mature. It is usual in English to call the varicties which are eaten raw, bananas; while those which must be cooked are called plantains.

Climate and Soil. The banana is a tropical plant, and most varietiesare killed by frost. It endures shade, but bears more fruit in the sunshine, in places where shade is not

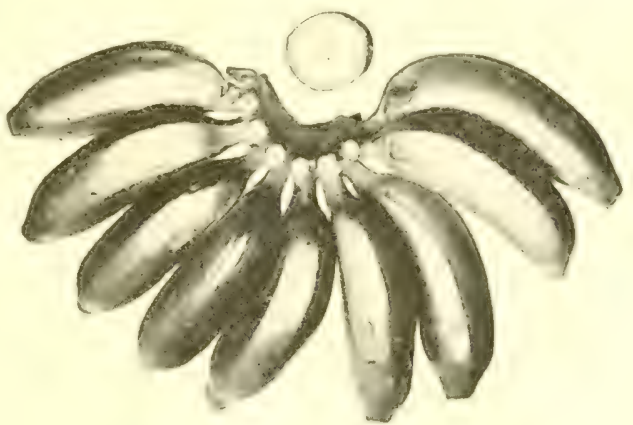

F1G. II5. The morada banana needed. Like abacá, it cannot endure wind, nor dry air, and must be sheltered and shaded if exposed to them. The soil, also, must be moist; the more water it contains the better, if it also contains air. Heavy soil is better than light. Rich soil is more necessary for the banana than for the abacá. Unless it is very rich, it should be fertilized freely.

Planting and Cultivation. Bananas are propagated by transplanting the suckers which grow up around old plants. If they bear any unrolled leaves, these leaves should be cut off. The ground should be fine and rich where bananas are to be planted. Half a kilo of ashes 
around each plant is an excellent fertilizer; but the ashes must be mised well with the soil, not put against the plant. Fior most varieties, 3 meters apart in each direction is a good distance in planting.

The surface of the ground must always be kept loose, and free of weeds until the shade of the bananas can keep them down. The ground cannot be cultivated deeply without injuring the roots. If all the suckers which spring from the base of a plant are allowed to live, the plant will produce little and poor fruit, or none at all. As a general rule only one sucker at a time should be allowed to grow, but there may be two if the soil is rich and the plants are far enough apart.

Time of Ripening. The time between planting and maturity varies from nine months to three years, depending on the variety of banana and on the conditions of growth.

When fully ripe, the banana is rich in sugar. Just before ripeness, this substance is mostly in the form of starch, and a very nowrishing meal can be made by drying bananas at this time and crushing them. The cooking bananas are commonly used before most of the starch turns to sugar.

\section{PAPAYA}

Description and Uses. This plant, whose name is Carica papaya, is another strictly tropical, quick-growing plant, whose stem is hardly woody enough to justify calling it a tree. 
Besides the ripe fruit, other parts of the plant are supposed to be useful in various ways. If the unripe fruit is feel to ducks and geeses, it is expected to cause an abundance of egers. It is given to human beings as a vermifuge. Soap is sometimes made from the leaves.

The milky juice contains a substance like that in the juice of the stomach, which can digest the fibers in meat, and so make the meat tender and easily digestible. There are many varieties of this nourishing fruit.

Papaya is always reproduced by seed, and may mature in as short a time as nine months. The fruit should be produced throughout the year.

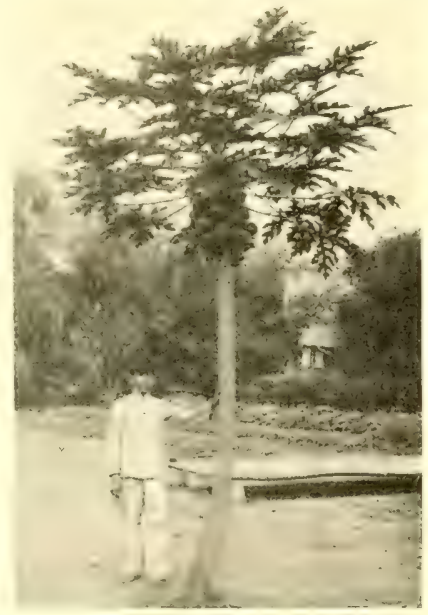

FIG. II6. Papaya tree in fruit

\section{CITRUS FRUITS}

History. Citrus is a genus of fruit trees, including all the kinds of oranges, lemons, limes (cabuyan), and pomelos, or lukban. As articles of commerce, these are the most important of tropical fruits; but the lands foremost in their porduction, Italy and California, are not really tropical. I number of species of citrus are cultivated; but the have been so mixed in cultivation, and so many new forms have been produced, that it is no longer possible to state what, or how many, the wild 
ancestors were. All are natives of southeastern Asia and Malaya.

In the Philippines. The rarieties cultivated in the Philippines are mostly not rery good, but the climate is excellent for them, and the best varietices can be casily introduced. Not every variety brought in can be expected to produce fine fruit here, but some of them are
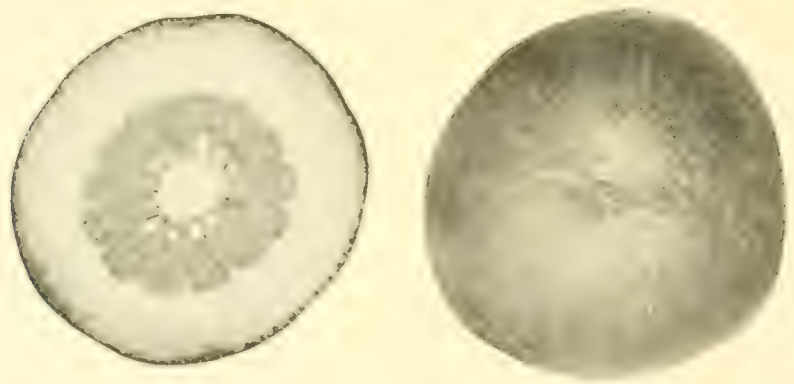

FIG. I17. Pomelo

sure to do so. The chief orange district in the Philippines is about Tanawan, in Batangas.

Varieties. Flavor and juiciness are the most important qualitics in an orange; after these come a loose skin and absence of seed. The finest oranges are the mandarin. the mavel, and the blosel. Each of these has many varieties. The mandarin is a native of China; the narel probably wriginated in Brazil; and the finest blood orange, in Malta.

Sonce of the l'hilippine oranges have a very func flavor, but they are tight-skinned, seedy, and fibrous. One of the best pomelos is the Chinese, the fruit of which is 
imported into Manila. A very fine and large lime grows in the Philippine forests.

Climate. The different varieties of citrus fruits make different demands on the climate. Some endure heave frost, while others will not thrive where the temperature ever approaches the freezing point. There is no place in the Philippines, at whatever altitude, where some of these should not thrive.
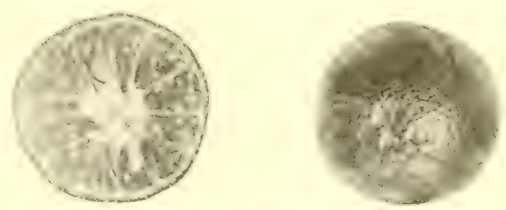

Fig., IIs. Orange

Soil. To permit the best growth, the soil must be fairly light, and without standing water within $150 \mathrm{~cm}$ of the surface; but most of the roots do not run deeply. The soil should be rich in potassium, and especially so in lime. No other tropical fruit endures dry air so well as these do, if they are irrigated.
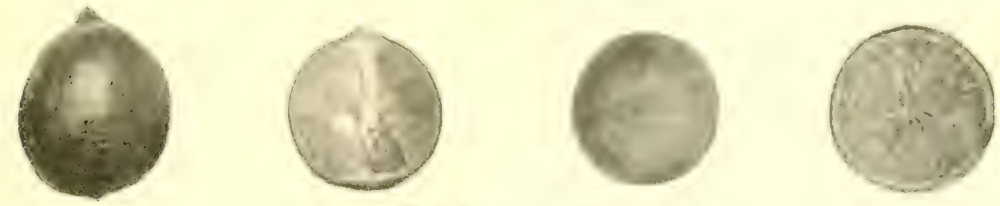

Firi. II.). Lemons

Propagation and Cultivation. The finer citrus fruits are reproduced by grafting. The seed of some strong and hardy lind is planterl, and on the stem of the seedling a small branch of the desired variety is grafted. Cirafting not only makes certain the kind of fruit that will be produced, but also gives a plant that produces two or more 
years sooner than if it had been grown directly from the seed.

In raising oranges, it is important to keep the ground well cultivated and free from weeds. Orange trees should be planted about + meters apart, and kept small enough not to be crowded.

\section{MANGO}

History. The choicest fruit in general cultivation in the Philippines is the mange, Mansifere india. This tree is a native of India, where its cultivation is very ancient. It also spread long ago over Malaya. It is

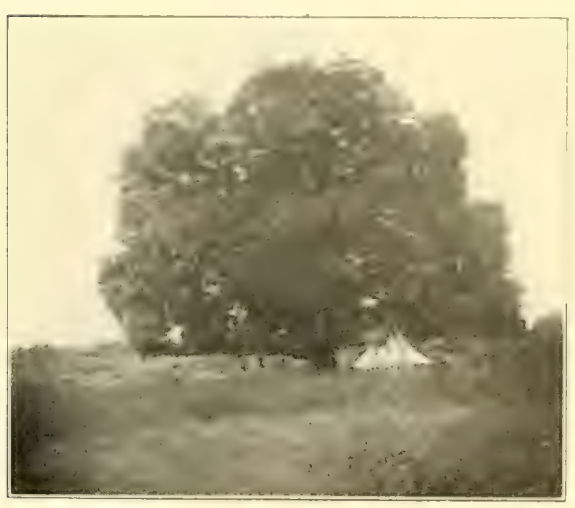

FIG. I20. Mango tree in the Philippines cultivated in all tropical countries. There are more than five hundred varieties in all India, and more than two hundred have been cultivated in a single grove. India and the Philippines are homes of the finest mangos.

Climate. The mango is a distinctively tropical fruit, and thrives best where the temperature is unifomly high. Strong wind is very injurious to it. It endures dry seasons well, but should be irrigated, if the ground is dry during flowering time or the following three months. Rain at flowering 
time is likely to do great damage by preventing pollination. frood mangen soil is rich, deep, and well drained. Bones are a good fertilizer.

Seed. The mangen is reproduced by seed or by grafting. The seed is short-lived; but it has been found in Hawaii that almost half of the seed will germinate, if kept a month before planting. It was also found there that if the hard shell is removed from the seed, the average time required for germination is i 8 clays, but that the average time with the shell left on is 40 days. The seeds should be placed on their sides.

Grafting. The easiest way of grafting mangos is that called inarching. A vigorous seedling about six months old, growing in a pot or large joint of bamboo, is put where its stem can be placed beside a small branch-stem of the variety desired. The two stems must be

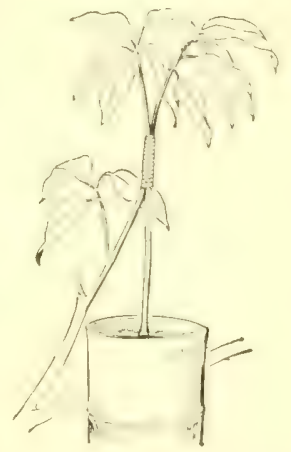

FIG. I2I. Inarching of the same size. Where they are in contact, a piece of the surface about ro cm long is then cut from each with a shary knife, learing a flat. smooth surface cut well into the wood. The two cut surfaces are then fastened together firmly, but without much presisure; the bark of one stem must fit the bark of the other.

The air is then kept away from the edges of the cut surfaces by means of grafting wax. A good liquid wax is made by melting together 160 grams of white resin and Io grams of beef tallow, and slowly adding so grams of 
alcohol. The alcohol must not be added while the mixture is over the fire.

After the two stems become well grown together, the branch is cut below the graft, and the top of the seedling is removed, leaving the end of the branch growing on the root of the seedling. It should then be set out in its permanent place as soon as possible. Plants can be transplanted whenever they are without young leaves. Ten meters between the trees is a good distance.

Cultivation. I ilie other plants, the mange will pay for cultivation of the shound by maturing sooner, and bearing larger crops. Smoking the trees is believed in the Philippines to stimulate the production of fruit; and the trees are hacked for the same purpose. This may increase the next crop of fruit, but only at the expense of the roots.

The price of the fruit depends upon the season. Experiments in Manila have shown that at a temperature of $14^{\circ}$ mangos not quite ripe will keep well for at least a month. This has also been found in Hawaii to be true at about $3^{\circ}$.

\section{MINOR FRUITS}

There are in the Philippines many fruits which are less important or less widely known than those which have been dencribed. Of these there are two, the durian and the mangosteren, each of which is sometimes called the most delicious of all fruits.

Mangosteen. The mangosteen is a native of the Moluccas, but has long been in cultivation as far as 
Bengal. In the Philippines it is found at l)apitan, and even in Negros, but is not common north of Jolo. The fruit is brought to Manila from Singapore.

The mangosteen is a small tree with dark red flowers and dark reddish brown, spotted fruit. The husk of the fruit is red where broken. Inside it is the white or rosy pulp.
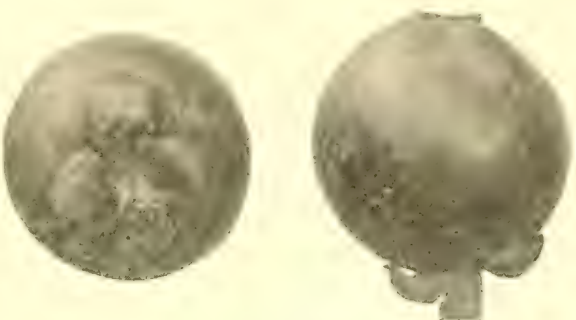

FIr. 122. Mangosteen

Fine mangosteens are almost seedless. In growing this fruit, care must be taken to secure rapid growth for some time after germination.

Santol is a very similar Philippine fruit, in the same family; but it has not the mangosteen's fine flavor.

Durian. The durian is
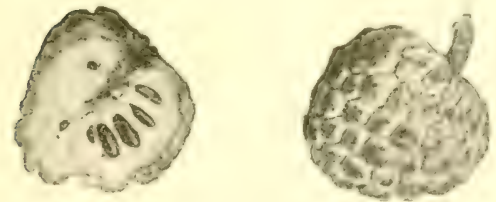

Fir. I23. Atis a huge fruit, ${ }_{5}$ to $20 \mathrm{~cm}$ in diameter, with a hard shell covered with pyramidai spines. It is a native of Malaya, now cultivated as far as $\mathrm{I}_{4}^{\circ}$ north in Siam, but unknown in the Philippines north of Mindanao. The trees are very large, and are said to bear in other places as many as two hunded fruits: but in Mindanas they usually bear very few. Inside the hard shell is a butter-like, creamy pulp, delicious in taste and vile in 
odor. When the season opens, single fruits sell in Singapore for two pesos.

Mabolo. The mabolo, Diospyros discolor, is a common Philippine fruit with good flavor, but unpleasant odor. Besides this species and many others in the

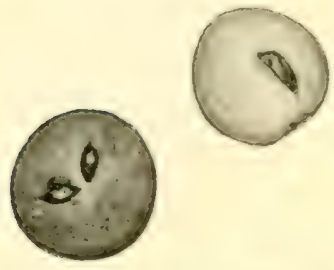

FIG. 12.4. Chico Philippines, the genus Diospyros contains the persimmons, which are a staple fruit of Japan. The heartwood of mabolo sometimes turns perfectly black, and is sold as ebony. Nore commonly; it is not all quite black; then it is called camagon. Other species of Diospyros also furnish ebony, and probably camagon as well.
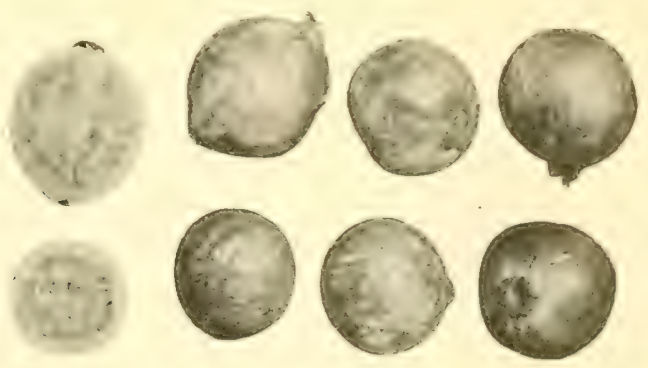

FIG. 125. Guavas

Lansones. Next to the mango, the most highly prized fruit on the Manila market is the lanson. This is a small fruit, two or three centimeters in diameter, but borne in large bunches. It has a thin skin, in which is a bitter, milky juice. Inside this the fruit has five divi- 
sions, each of which, in the wild lanson, ustally contain. a seed. As a result of cultivation and selection, and propagation by cuttings, four of these seeds and sometimes all five, have become very small and tastelesis.

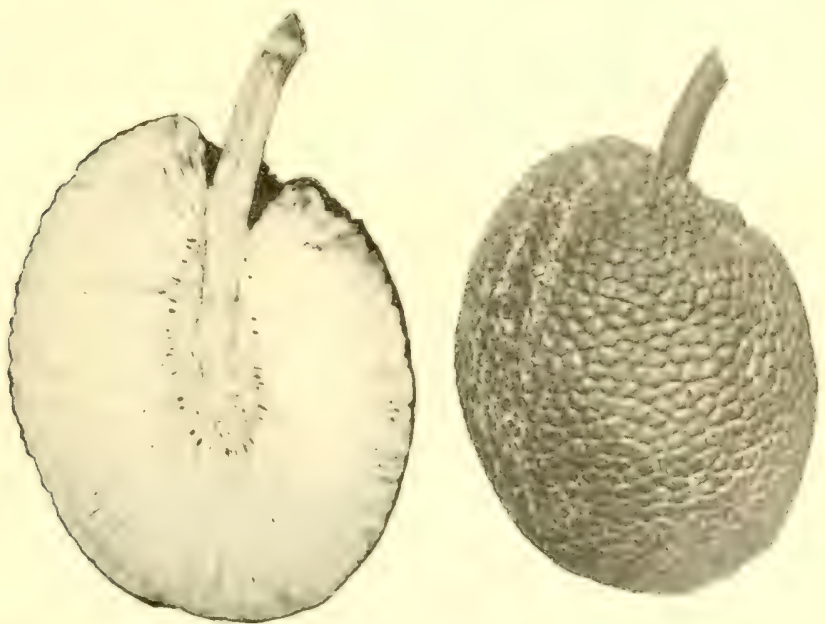

FIG, I26. Breadfruit

The remaining seed is large and bitter, and not edible. Young trees begin to produce whein about five vears old, and when mature are six meters or mere in height.

In Java the seed of lansones are used as a vermifuge, and the fresh skin of the fruit is rubber on the body after bathing.

The Genus Anona. The genus Anoma includes nerveral Philippine fruits, - the atis, or sweet sop), anomas, and aour sop, or guanábano. All of these are natives of . Imerica and grow only in the tropics. The sweet nop has sereral 
ovaries in each flower, and these remain separable in fruit. Its seed, ground fine, serves as an insecticide, which is used, for instance, to kill the insects on dogs. The custard apple, or cherimoya, is usually called the finest of the fruits in this genus; it has not been introduced into the Philippines. The ilangilang is a tree in this family.

Other Fruits. Among the numerous other Philippine fruits are the chico; the chico mamey, a fine fruit which seems now to be cultivated only at Alfonso in Cavite; antipolo, or camansi, the breadfruit; nangka, the jackfruit; bilimbi; iba; casoy; and guava.

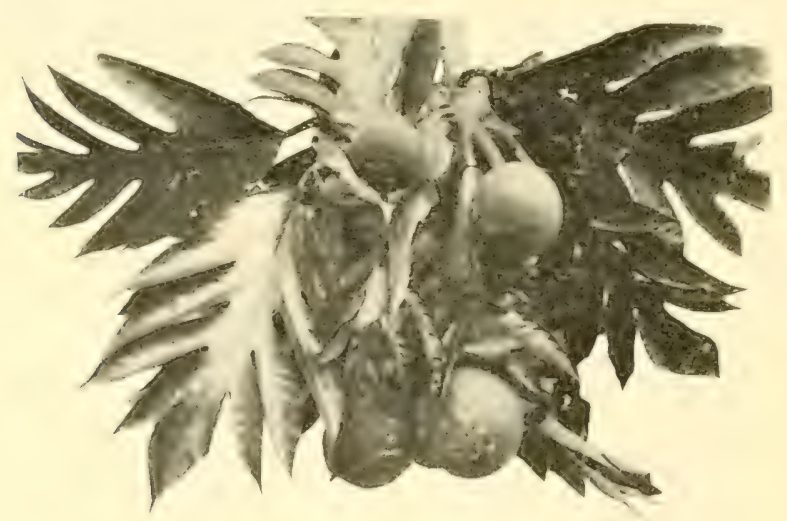




\section{GIOSSARI}

Anther. See Flower.

Bacteria. The smallest, and probably the most primitive, living things. They are without chlorombyll, and most of them must obtain their food as animals do, from animals and plants. "There are many kinds, of which a few cause disease. Consumption and cholera are human diseases caused by bacteria.

Bract. A specialized leaf, in or just below an inflorescence. Bracts are usually simple and smaller than other leaves, or they are not green.

Calcium. An element widespread in the soil, making up a large part of limestone, marble, pearls, gypsum, and chalk. It is an especially valuable fertilizer for crops not raised for the seed or fruit, and for legumes.

Capsule. A dry fruit, which opens when ripe and lets the seed escape. It is composed of two or more carpels. Examples: tobacco, okra, cotton.

Carbon. An element found free in two forms, as diamond and as graphite (the "lead" of lead pencils). In combination it is found in every part of every living thing.

Carbon dioxid. A gas, formed by the union of carbon and oxygen. All living things form carbon dioxid at all times; but green plants destroy it in sunlight. It is given off by animals when they breathe.

Carpel. See Flower.

Cell. The unit of structure of living things. Some living things, as bacteria, are single cells, but most are made up of many cells. The parts of a plant cell are usually: I. The protoplasm, or living part of the cell. 2. The vacuoles, cavities in the protoplasm, full of water and substances dissolved in the water. 3. The cell wall, a hard substance, inclosing the protoplasm. Cells of animals have no wall, or else one not made of cellulose.

Conservation. Saving up; keeping.

Epidermis. A single layer of cells, cov. ering every part of the plant except the root cap.

Export. To send for sale or exchange to other countries or places. The exports of a country or place are the things sent out of it. The things brought in are imports.

Flower. A flower is the end of a shoot or branch, which has given up the vegetative function and become specialized as a reproductive structure. Its parts are the end of the stem, called the receptacle, and, if the flower is complete, four kinds of leaves : - 
Sepils. These are the outermost. They are usually green in color, but small. All together, they make up the calyx. Petals. These are inside the calyx. They are usually larger than the sepals and showy in form or color. The petals make up the corolla.

Stamens. These are borme in or upon the corolla. Each stamen is made up of a slender stalk, called the filament, and an enlarged enc, usually yellow, called the anther. The anther is full of a fine powder called pollen.

Carpels. These are the central leaves of the flower, but usually do not look at all like leaves. A flower may have one or more of them. Any one carpel not united with others, or a union of several of them, makes a pistil. A flower of most kinds of plants has but one pistil; but a few kinds, as the ilangilang and atis, have many. The parts of the pistil are: 1. The enlarged, hollow, basal part, the ovary, which contains ovules. 2. The upper part, the stigma, on which the pollen must fall and germinate. 3. The style, which connects the ovary and stigma. Some flowers have no style. Pistillate flowers contain pistils but no stamens. Staminate flowers have stamens, but no pistils. Flowers with both stamens and pistils are perfect.

Germination. The beginning to grow of a seed or spore.

Hybrid. A plant or animal whose parents are of different kinds. The mule is a hybrid between the horse and the ass.
Induction coil. An apparatus for producing electric currents by induction. Induction is the causing of a current in one body by a current in another body, when the two bodies are not in contact. In induction coils the wires are usually wound with silk, to keep them from touching each other.

Inflorescence. A collection of flowers growing on a special part of a plant. All the flowers on an ear of maize, or at the top of one stem of tobacco or rice, make up an influrescence.

Internal revenue. All the revenue or income of a country, except that collected by taxes on exports or imports.

Litmus paper. Paper treated with a sul)stance which makes it blue when alkaline, but red when acid. An acid is a sour substance, such as vinegar. Lime and ashes are alkaline.

Node. The part of a stem where leaves and branches are borne.

Panicle. A branched inflorescence, in which the lower flowers blossom before those at the top.

Parasite. Any living thing which gets its food from some other living (not dead) thing.

Petal. See Flower.

Petiole. The part of the leaf which is stem-like. A leaf without a petiole is sessile.

Pistil. See Flower.

Pollen. See Flower.

Propagation. See Reproduction.

Proteids. Food substances which are 
very complicated and contain nitrogen. The white of eggs is a proteid.

Protoplasm. See Cell.

Reproduction. The process by which living things that alrearly exist produce or bear new living things of the same kinds. When reproduction increases the number, or produces the offspring in new places, it is often called propagation.

Sepal. See Flonier.

Spore. A reproductive structure, usually made up of a single cell. Spores are very much smaller than seeds. The fungi, seaweeds, mosses, and ferns are propagated by means of spores, instead of seeds.
Stamen. See Tlower.

Sterilize. To make anything sterile, so that nothing will grow in it. The suil, or any other substance, is sterilized when the seeds, spores, and other living things in it are killed.

Stigma. See Hlower.

Style. See Flower.

Subsoil. A layer of the carth often found under the real soil, but above the rock. The most important character of most subsoils is their permitting, or not permitting, the passage of water.

Vegetative parts of plants. Those parts whose function is to buila up the inclividual piant, not to produce its offspring. 


\section{INDEX}

Abacá, I33-143; effect of cultivation, 42 ; effect of shading, 33 .

Agave, I44.

Agriculture, $r$.

Alluvial soil, I9.

Altitude, 51.

Ampalaya, 74.

Ananassa, Ifo.

Anona, 185.

Anther, I87.

Ants, 65 .

Arachis, 77 .

Arid land, uses, 43.

Arrowroot, SS.

Arsenic, 56.

Ashes, 28.

Bacteria, 53, 187 .

Bagasse, I 20.

Banana, I 73-1 76 .

Batangas, coffee, I62.

Batao, 77.

Beans, 76 .

Beet, 69.

Blue vitriol, 59.

Bordeaux mixture, 59.

Bow-string hemp, I 49 .

Bract, I87.

Breadfruit, I86.

Buhac, 57.

Cabbage, 72 .

Cacao, I68-I72.

Cagyos, 77.

Caingin system, 30 .

Cajanus, 77 .

Calcium, 27, 187.

Camagon, I84.

Camoting cahoy, $82-86$.

Canal, irrigating, 45 .

Cane, sugar, II 2-I2I.

Capsule, I87.

Carbon, 25.
Carbon dioxid, 32, 187 .

Carica papaya, I 76 .

Carrot, 69, 70.

Cassava, 82-86.

Cell, 187 .

Chico, I86.

Chico mamey, I86.

Chlorophyll, 4, 32 .

Cincomas, 70, 76 .

Citrus, $177^{-1 S o}$.

Clay, 22; dries badly, 42 .

Climate, 46-52.

Coconut, I $22-132$; distance between plants, 34; numerous roots, 39; seed, 12; beetle, 54 .

Cocos nucifera, I 22.

Coffea, 160.

Coffee, 160-167; insect enemies of, 54; rust, 58-60, I64, I67.

Coir, I23, I32.

Colocasia, 68.

Conservation, 187 .

Copper sulphate, 50-60.

Copra, I23, I32.

Corn, 90.

Cotton, I48.

Cotyledons, 8, I 2.

Cucumber, 73,75 .

Cultivation, effect on soil water, $4 \mathrm{I}, 42$; to drive away ants, 65 ; to dry the soil, 63 .

Curing tobacco, I54, I59.

Dapdap, r39.

Dicotyledons, $\mathrm{I} 2$.

Dioscorea, 68.

Diospyros, IS4.

Diseases of plants, 53 .

Drainage, 38 .

I Drill, IOI; rice, IO9, IIO.
Drought, effect on coconut, 128 ; effect on maguey, 143 .

Dry seasons, where likely, 50.

Durian, $18_{3}$.

Eggplant, 8o.

Elements, chemical, 2427.

Embryo, Io.

Endosperm, II.

Epidermis, I87.

Export, 187.

Fertilizers, 27-30, 6.4 .

Fiber plants, I33-I 49 .

Flower, 10, 187; of maize, gr.

Fodder, maize, 94-IoI ; peanut, 77 .

Frost, 47 .

Fruit, I5, I73-IS6; garden, 79-8I.

Fungi, 5, 58-6o.

Gabi, 68.

Garden, $69-8$ I.

Germination, 188 .

Glucose, I I 9 .

Gossypium, I48.

Gourd, 73.

Grafting, mango, I8I, I82.

Grafting wax, I8I.

Green manures, 29.

Guano, 28.

Guava, IS4.

Hairs, on tobacco leaves, I 50.

Hemp, Manila. See Abacá.

Hills, of maize, Ioo; of squashes, 73 .

Humus, 20. 
Hybrid, I S8.

Hydrogen, 25, 26, 35 .

Inarching, I $8 \mathrm{I}$.

Indigo, 79 .

Induction coil, 188 .

Inflorescence, ISS.

Insects, 53-58.

Internal revenue, 188.

Ipomaa, 67.

Iron, 25, 26; and tobacco, 155 .

Irrigation, $43-45 ;$ of cane, IIS.

Isabela, tobacco, I 53 .

Japanese rice, Iof.

Java, rice production, 105.

Jute, If9.

Kapok, I49.

Kerosene emulsion, 57 ; to kill insects, 56 ; to protect seed, 65 .

Lanson, I $\varepsilon_{4}$.

Leaf, parts of, 9 .

Leaf crops, 71,72 .

Legume family, 29, $75-79$.

Lemon, 177 .

Lettuce, 73 ; effect of cultivation, $4 \mathrm{I}$.

Liberian coffec, $\mathrm{I}_{3}$.

Light, 32-34; amount at Parí and Kew, 47 .

Lime, fruit, 177 .

Lime, and tobacco, i5t; in Bordeaux mixture, 6o. See Calcium.

Lipa, coffee, I62.

Litmus paper, ISS.

Loam, 22.

Locusts, 55 .

Loess, IS.

Mabolo, is 4 .

Madrecacao, I39.

Magnesium, 25.

Maguey, I43-I.46.

Maize, 90-ro2; insect enemies of, 54,56 ; smut, 58 .
Mangifera, tSo.

Mango, ISo-I 82 .

Mangosteen, I 82 .

Mani, 77,78 .

Manihot, 82 .

Maniok, $82-86$.

Manure, for fertilizer, 28.

Melons, 73,75 .

Metamorphosis of insects, 54.

Micropyle, I I, I3.

Mindanao, coffee, I63.

Mineral food, dissolved in water, 36 .

Moisture, a factor of climate, 46.

Mold, 20.

Monocotyledons, I 2.

Mulch, 42 .

Mungo, 76 .

Musa, I33.

Musa textilis, I33.

Mushrooms, 5 .

Mustard, 7 I.

Name (Philippine yam), 68.

Names, of plants, 6 .

Nicotiana, I50.

Nicotine, $I_{5} \mathrm{I}$.

Night-flying insects, 56 .

Nitrogen, 28, 29; used by maniok, 8 .

Node, I88.

Nodules, on roots of legumes, $7^{6}$.

Okra, 79 .

Onion, 70 .

Orange, $177-1$ So.

Orchard, 6I.

Origin, of soil, I6-Is.

Oryza, IO3.

Ovary, Io.

Ovule, Io.

Oxygen, 25.

Palms, I 22.

Pangasinan, rice production, I05.
Panicle, 188.

Papaya, г76, г77.

Paper, abacá, I35.

Paper materials, $1+2$.

Paquit, 68.

Parasite, I88.

Paris green, 56.

Parsnip, 70.

Paths, in garden, 63.

Pea, 76 .

Peanut, $77-79$.

Pe chai, 72.

Pepper, $\delta_{\text {I. }}$.

Persian insect powder, 57.

Petiole, 188.

Phaseolus, 6.

Phosphorus, 25, 28 .

Pineapple, $\mathrm{I} 46-\mathrm{I} 48$.

Pistil, I88.

Plants, 3-IO; food of, 3 , $2.4-31$; parts of, 8 .

Plumule, II, I3.

Pollen, I88; of maize, 92.

Pomelo, I 77, I 78 .

Potassium, 25.

Potato, 86, 87.

Propagation, 188.

Proteids, 76.

Protoplasm, I So.

Prussic acid, 83.

Pumps, for irrigation, +3 .

Radicle, II, I3.

Radish, 70.

Rainfall, and altitude, $5 \mathrm{I}$;

in Philippines, 48.

Ramic, I 49 .

Rattan, I49.

Reproduction, I89.

Residual soil, I8.

Rhizome, 88.

Rice, I03-III.

Root, 8, 39.

Root crops, 66-7o.

Root hairs, 39 .

Rotation of crops, $3 \mathrm{I}$.

Saccharum, I I3.

Sand, 2 I.

Santol, I83.

Seaweeds, 5 . 
Seed, IO, II-I5; of abacá, 139 .

Seed beds, 65, 66.

Seed coats, II, I3.

Selection of seed, of coconut, I20; of maize, 97.

Shade, 33; and abacá, I.39.

Shade trees, 3.3, I39.

Shoot, Q.

Silk-cotton tree, I49.

Sinamay, 134 .

Sisal, 144 .

Sitao, 77 .

Soil, I6-23; cultivation for maize, 98 ; in garden, 63,64 .

Solanum, 86.

Sour sop, IS5.

Spore, 189 ; of fungi, 58 .

Squashes, 7375 .

Squash, seed, I3.

Stamens, I8\%.

Starch, 32, 82-89; in banana, I76; manufacture, 85 ; rice, Io6.

Starch plants, 82-S9.

Stem, o.

Sterilize, ISo.

Stigma, ISo.
Storage, of mango, 182.

Stripping abacá, $14 \mathrm{I}$.

Structure of soil, $2 \mathrm{I}-23$.

Style, I89; of maize, 92.

Subsoil, 189 .

Sugar, 32 ; cane, I I 2-I 2 I.

Sulphur, 25.

Sumatra tobacco, I55, I 50 .

Sweet potato, 67 .

Sweet sop, 185 .

Talahib, I 3.3 .

Talong, So.

Tapioca, 86.

Taro, 68 .

Tax, on tobacco, 152.

Tegmen, I I, I3.

Temperature, in Philippines, 46; of coconut leaf, 126.

$T$ istit, 11,$1 ;$.

Texas, rice cultivation, IOU.

Threshing machine, I I I

Tobacco, I5O-I59; need of shade, 34; used in fighting insects, 56 .

Tomato, 8o.

Tools, 64 .
Transpiration, 36 .

Transpiration stream, 36 .

Transplanting, 40; rice, I08.

Tuba, I23.

'Tuber, 86.

Tugui, 68.

Turnip, 70.

Ubi, 68 .

Upo, 74 .

Vacuoles, 35 .

Vegetative parts of plants, I 89 .

Water, 35-45; about soil particles, $38,4 I$; in beach soil, I 27; in soil, 22, 63; movement, 42 .

Weather and formation of soil, 17 .

Weeds, 34 .

Wild rice, I04.

IVindmills, 43 .

Worms, causing disease, 53.

Yam, 68.

Zea, 90.

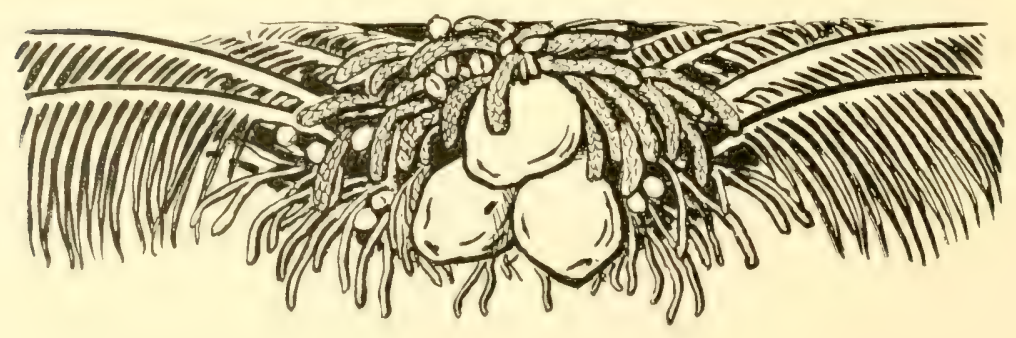



DEC \& 1908 



\section{LIBRARY OF CONGRESS

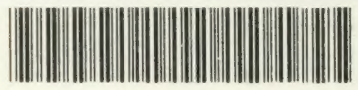 0002693936?}

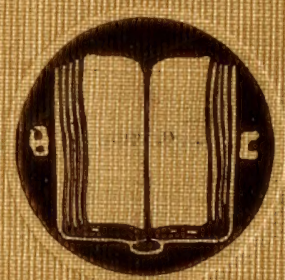

